BIS WORKING PAPERS

No. 86 - March 2000

\title{
INFORMATION, LIQUIDITY AND RISK IN THE INTERNATIONAL INTERBANK MARKET: \\ IMPLICIT GUARANTEES AND PRIVATE CREDIT MARKET FAILURE
}

by

Henri Bernard and

Joseph Bisignano

BANK FOR INTERNATIONAL SETTLEMENTS

Monetary and Economic Department

Basel, Switzerland 
BIS Working Papers are written by members of the Monetary and Economic Department of the Bank for International Settlements, and from time to time by other economists, and are published by the Bank. The papers are on subjects of topical interest and are technical in character. The views expressed in them are those of their authors and not necessarily the views of the BIS.

Copies of publications are available from:

Bank for International Settlements

Information, Press \& Library Services

$\mathrm{CH}-4002$ Basel, Switzerland

Fax: +41 61 / 2809100 and +4161/2808100

This publication is available on the BIS website (www.bis.org).

(C) Bank for International Settlements 2000.

All rights reserved. Brief excerpts may be reproduced or translated provided the source is stated. 
BIS WORKING PAPERS

No. 86 - March 2000

\title{
INFORMATION, LIQUIDITY AND RISK IN THE INTERNATIONAL INTERBANK MARKET: IMPLICIT GUARANTEES AND PRIVATE CREDIT MARKET FAILURE
}

by

\author{
Henri Bernard and \\ Joseph Bisignano*
}

\begin{abstract}
This paper considers the functioning of the international interbank market (IIBM), its contribution to the recent financial turbulence in Asia, and the policy issues presented by the existence of moral hazard and implicit guarantees of interbank liabilities. The paper provides statistical analysis to document the existence of contagion in the interbank market. While previous researchers had cautioned of the possibility of contagion in the IIBM, statistical support for its existence was relatively sparse. Within geographic regions, interbank market contagion appears much more prevalent within Asia than within Latin America. Between regions, the contagion appears to have been from Asia to Latin America. The paper discusses the possible role of implicit government guarantees of international interbank credit in contributing to inflows into emerging market countries, where significant information asymmetries made difficult the analysis of counterpart risk. It is argued that because of the serious informational problems in some segments of the international interbank system, the market is subject to potential disruption. The implicit guarantees given to risky borrowers in the IIBM can be thought of as a subsidy which helps to ensure the viability of the market. In principle, it is similar to a subsidy that is provided a market with extreme adverse selection problems. It can, however, also be a source of instability if not properly managed.
\end{abstract}

We wish to thank participants at seminars at the Universitá di Brescia, the Banco Central de la Republica Argentina, the Banco Central do Brasil and at the conference "What financial system for the year 2000?" sponsored by the Instituto Superior de Economia (ISEG-UTL), Lisbon, Portugal in December 1999. The views expressed in this paper are those of the authors and in no way represent an official position of the Bank for International Settlements. 



\section{Contents}

1. Introduction

2. The fundamental dilemma in the international interbank market (IIBM)

3. Credit rationing and contagion in the IIBM

3.1 Origins of credit rationing in the IIBM

3.2 Changing perceptions of bank credit risk ............................................. 12

3.3 Recent behaviour of international interbank activity: the liquidity valve ..... 19

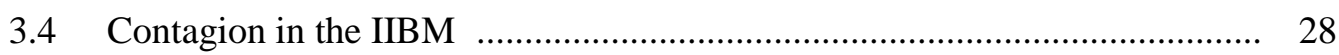

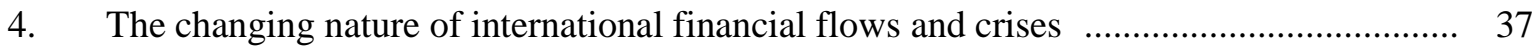

4.1 Push and pull of capital flow crises ……............................................... 37

4.2 Moral hazard, implicit and explicit guarantees and the restoration of

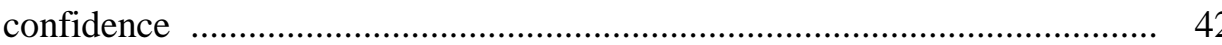

4.3 Excess liquidity, credit rationing and the risk of interbank market failure $\ldots \quad 47$

4.4 When private liquidity markets collapse f............................................... 53

5. Resolving the problem of the abuse of implicit guarantees in the IIBM

5.1 Externalities and deposit guarantees without ex ante guarantors: a public economics perspective

5.2 A variation on the Merton-Bodie paradigm of the management of guarantees

6. Conclusion 



\section{Introduction}

In October 1992 a working group of the Group of Ten countries' central banks published a report on the changing structure of the international interbank market. ${ }^{1}$ The report focused attention on how derivative instruments have altered the structure of the traditional international interbank market (IIBM), how linkages between different segments of the financial markets have increased, and how these linkages have blurred the distinction between domestic and international financial markets. In the light of the financial crises which engulfed emerging markets in Asia and Latin America, the prolonged disruption in the Japanese financial sector and the turmoil in mature financial markets following the Russian debt moratorium, one conclusion of the report stands out in particular:

“... the heightened concern with credit risk, reflecting both a perception of increased default risk and greater difficulties in assessing counterparties' strength, has led many banks to reduce the size of interbank credit exposures that can be authorised, to shorten the maturity of the business they are willing to take on, and to limit dealing activities that yield low profits but give rise to large counterparty exposures" (pp. 1-2).

Contrast the above statement with the following taken from the "Report of the Working Group on Strengthening Financial Systems", one of the documents of the Group of 22 "Willard Report" written in 1998 following the financial crises in Asia:

"Recent crises in emerging markets have highlighted the importance of liquidity management in foreign as well as domestic currency. ... Two areas of particular concern are the maturity structure of public sector debt (an issue in Mexico in 1994 and in Russia today) and also the short-term liquidity of the banking sector as a whole (important in Korea in 1997 and in Argentina in 1995). ... The size of the maturity mismatches and currency exposures that were built up in South-East Asia illustrates the points just made. The scale of short-term borrowing, generally in foreign currency, was substantial. Of the US $\$ 380$ billion in international bank lending to Asian countries outstanding at end-1997, $60 \%$ had a maturity of less than one year. ... In many cases decisions by borrowers to rely on short-term foreign currency finance rested on the twin presumptions that the exchange rate would be maintained and that short-term borrowing could be rolled over. In the event neither presumption proved to be warranted" (pp. 11, 13).

Several events in financial markets since the crisis in South-east Asia erupted in July 1997 both confirm and contradict certain aspects of these two reports, which helped to motivate this paper, a reexamination of the international interbank market. The considerable concentration in some of the derivatives markets has indeed increased concern with creditworthiness of counterparties. At the same time it is curious that the assumed greater concern with counterparty risk was not later reflected in the figures for international interbank lending to emerging market countries, particularly those in Asia. Interbank lending to Asia grew enormously prior to the crisis, at times with arguably little recognition

1 See Bank for International Settlements (1992). 
of the quality of the borrowing institution. International interbank credit also declined dramatically after the crisis erupted, contributing to a major collapse in economic activity. The two reports would appear to contradict one another, one suggesting greater concern with credit risk, the other indicating excessive lending in the interbank market and a serious lack of credit screening and monitoring.

The international interbank market played a major funding role for Asian emerging market countries during the 1990s, which in comparison makes its role during the 1980s for Latin American countries look modest. The market performed a very large maturity transformation on an international scale, turning short-term implicitly insured deposits into long-term loans, and a large risk transformation, transferring deposits from major international banks to intermediaries in developing countries of lower credit standing. It was well known that a significant global maturity transformation was taking place, as can be seen in the statement from a report by G10 Deputies (the "Rey Report") before the outbreak of the Asian crisis.

"International interbank lines constitute a sizeable portion of some emerging economies' total debt, and banks in these countries fund long-term domestic claims in the international interbank market" (Group of Ten (1996), p. 6).

During the 1990s the interbank market had plenty of liquidity to redistribute around the globe, provided by countries with large current account surpluses and weak domestic loan demand.

This paper's aim is to review the structure of the international interbank market in the light of the recent Asian financial crisis. Before we begin it should be noted that the subject of this paper is part of a much broader current debate, namely on the desirability of capital account convertibility and the promotion of financial liberalisation in emerging market countries. On the one side of the debate is the view, recently expressed by Stanley Fischer (1998, p. 2), that capital account liberalisation "is an inevitable step on the path of development, which cannot be avoided and should be embraced." On the other side is the opinion such as that of Jagdish Bhagwati (1998, p. 12) that the benefits of free capital mobility are greatly exaggerated, that "the weight of evidence and the force of logic point in the opposite direction, toward restraints on capital flows." The behaviour of the international interbank market is an integral part of this debate and one in need of research attention.

The paper is structured as follows. We first consider what we believe to be a fundamental dilemma in the stance of central bank policy towards the IIBM, the desire on the one hand to promote liquidity in the international banking system and, on the other, to minimise the potential for moral hazard. Policy actions during past international financial crises have had the undesirable effect of imparting the perception of implicit guarantees of international interbank liabilities, while changes in financial structures now require a greater assurance of liquid financial markets. The present danger is that of an inadvertent increase in the moral hazard problem facing central banks and international official institutions. Next we consider the origins of credit rationing in the IIBM and its recent behaviour. We also investigate the existence of contagion at the time of the Asian financial crisis. Section 4 looks at 
the changing nature of international financial flows and the shift to an excess supply of short-term international liquidity during the 1990s. This section also takes up the issue of the risk of interbank market failure. Section 5 argues that the problem of implicit government guarantees to the interbank market needs to be addressed. Participants in the IIBM can be thought of as having the benefit of implicit deposit insurance without actually having to pay for it. Rather than argue that these implicit guarantees should be removed, something we find both difficult to do and difficult to make credible, we suggest a shift in focus to one of how best to "manage" implicit interbank deposit guarantees, alternatively, through greater monitoring, asset restrictions, or in the extreme, the imposition of "ex post deposit insurance premiums". We conclude by emphasising the need for greater policy attention to a market which has both improved the efficiency of the international financial system and at times been a source of its increasing vulnerability.

\section{The fundamental dilemma in the international interbank market (IIBM)}

The international interbank market was initially an informal market of short-term placements of deposits at fixed rates between banks in different countries. Its primary functions were to provide a means for liquidity adjustments by banks, thereby improving the allocation of deposits worldwide, to assist in the management of foreign exchange risk, and to minimise or avoid the costs imposed by domestic regulations. It was also said to be a means by which banks gained information on counterparties in international markets. As a result of the development of a variety of derivative instruments to both manage and assume market risk, in recent years the deposit side of the IIBM has become much more of a funding market. Nonetheless, the essential functions of the IIBM can be roughly summarised as being related to liquidity, information and risk management. ${ }^{2}$ It should be understood that the derivatives markets are now an integral part of the IIBM. We are here primarily concerned with the deposit market.

From the inception of the euromarkets a common perception has been that the IIBM was "special", in that deposit placements were in large banks "that the market believed would be supported by their respective central banks and that veiled the operations of individual customers in secrecy. Moreover, the history of cooperation among the monetary authorities of the major countries provided a basis for the markets' belief that no large institution chartered in one of those countries would be allowed to fail even where the bulk of its liabilities were denominated in a currency other than the one issued by the country in which it was chartered". ${ }^{3}$ Clarke (1983) reports that in the early 1980 s more than $60 \%$ of

2 Early writers on the subject include Giddy (1981), Clarke (1983), Herring (1985) and Dematté (1981). A description of the market as of the early 1980s is provided in the "Holland Report" (Bank for International Settlements (1983)).

3 Clarke (1983), p.9. 
the international interbank deposits of US charter banks and their foreign branches were placed in banks in the G10 countries. The market is now much more international. The system for the international allocation of banking liquidity was clearly thought to be protected by an informal agreement among central banks. From the beginning writers on the IIBM have been concerned that this perception reduced the incentives for participants in the market to closely monitor counterparty risk. Public sector officials and academic economists have periodically expressed concerns over what appeared to be the lax standards of credit analysis in the interbank market. ${ }^{4}$

The perception of implicit guarantees of international interbank lending continued and may even have grown over time. The importance of the IIBM in reallocating international liquidity following the two increases in crude oil prices during the 1970s encouraged this view. Central bank support for the IIBM during the Mexican crisis in 1982 to help sustain interbank flows to Latin America reinforced the opinion that the major participants in this market would not be allowed to default. The assumption of implicit official insurance was also thought to have helped the banking system compete with capital markets in lending to developing countries. ${ }^{5}$ The 1992 study of the IIBM by the G10 central banks noted in interviews with participants in the interbank markets that "there seems to be a certain degree of complacency with respect to systemic risk. This appears to be fostered by a more or less firmly held belief that central banks or public authorities would act to prevent any disruptions from reaching systemic proportions. A number of participants maintained that the confidence with which this conviction is held acted to stabilise markets. ${ }^{6}$ However, some participants said that they were fully aware that the policy response of central banks or other public authorities to financial disturbances may not necessarily be homogeneous." (Bank for International Settlements, (1992), p. 19.) Later in this paper we will argue that because of the severe adverse selection problems in the IIBM certain segments of the market might collapse without guarantees. (These guarantees function much like domestic deposit insurance.) More recently, we have seen implicit guarantees turn into explicit guarantees of international interbank deposits. Following the financial crisis in South Korea, bank creditors rescheduled their interbank lending for a three-year period at the US Treasury bill rate plus 250 basis points, for which they received a government guarantee.

The fundamental dilemma in the IIBM is that implicit guarantees which arguably may appear necessary to sustain the market have had the undesirable effect of lowering the scrutiny of potential

$4 \quad$ See Guttentag and Herring (1985) and Bank for International Settlements (1983).

5 See Folkerts-Landau (1995) and Chadha and Folkerts-Landau (1997).

6 The reason for the emphasis on this sentence will become apparent later when the stability of the IIBM is discussed. 
borrowers exercised by lending banks. At the heart of the IIBM lies a generic moral hazard problem: central banks face a potentially large contingent liability to the international banking system. ${ }^{7}$

Developments in financial technology and markets since the 1980s have in many ways increased the importance of the IIBM and the moral hazard problem confronting central banks. The reason is the growing need for "liquidity" in financial markets, the need to allocate this liquidity quickly and efficiently and to provide assurances that it will be available in times of market stress. Several factors have contributed to the growing demand for liquidity: the relative increase in short-term liabilities of intermediaries, reflected in the greater degree of short-term international lending during the 1990s; the securitisation of assets previously held to maturity on intermediary balance sheets; the enormous increase in domestic and cross-border trading volumes of financial assets; the move to real-time gross settlement systems in many countries; the demand for liquidity to support derivatives activities (e.g. margining), by both end-users and market-makers; and the greater proprietary trading activities of financial intermediaries. ${ }^{8}$ Also important has been the trend for banks to provide contingent lines of credit to potential borrowers, both as backup for the issuance of commercial paper and as alternative lines of credit to capital market borrowing.

The demand for liquidity and its efficient allocation emanates from the need to ensure the liquidity of the banking system and the increasing necessity to ensure the stability of organised securities exchanges and over-the-counter (OTC) markets. The growth of OTC markets has posed a particular challenge to policymakers given that their opaqueness can during periods of market stress lead to a rapid disappearance of liquidity. Liquidity demands can also increase as a result of the use of OTC derivative instruments to provide leverage to market participants. As in the recent case of Long-Term Capital Management (LTCM), such leverage can potentially alter market price dynamics and at times lead to rapid and large liquidations of positions, creating strong and immediate demands for liquidity.

The growing need for liquidity and liquidity assurances as a result of these factors, and in particular the complex financial positions that can be created with OTC derivatives, has raised the potential for greater liquidity risk in financial markets. Banks heavily engaged in OTC derivatives activities are likely to have much greater need for liquid balance sheets than those engaged in traditional on-balance sheet banking business. The greater opacity of financial institutions' on- and off-balance sheet positions has made credit analysis more difficult, at times threatening a curtailment in private market provision of liquidity and credit when confronted with a financial shock, similar to that which occurred following the Russian debt moratorium in August 1998. Thus, what we have observed is an

7 With regard to whose contingent liability it really is, Standard \& Poor's has always considered bank liabilities to be contingent liabilities of governments in the calculation of sovereign ratings.

8 The "Promisel Report" (Bank for International Settlements (1992)) noted a major increase in cash funding requirements of banks and securities houses as a result of their derivatives activities. 
increase in the demands for liquidity as a result of the transformation of financial instruments, institutions and markets, much less transparency hampering the quality of credit analysis and, as a result, greater risk of liquidity strains with possible systemic implications. The need to ensure the stability of the IIBM has risen pari passu.

It might also be said that practical considerations in the international interbank are made more complicated by theoretical ones. Bhattacharya and Gale (1987) have shown that in a competitive market for interbank loans, where participants handle unanticipated demands for liquidity by borrowing and lending to one another, ready access to the market increases the incentive for participating banks to underinvest in liquid assets." Hence a "free rider" problem results, all participants believing that they can turn to the interbank market when faced with a sudden demand for liquidity which, because of lack of coordination among them, can at times be in serious short supply. Given each bank's imperfect information on the liquidity and investment position of its competitors, one implication is the need for some centralised institution to improve the information sharing in the market or to improve the nature of interbank lending contracts. These concerns raise the policy issues of the possible role of deposit insurance, lender of last resort and a network of guaranteed credit commitments among banks. We will later touch on some of these issues.

The fundamental dilemma in the IIBM can be said to have increased significantly over the past decade as a result of the integration of emerging market countries into the fold of international finance and the greater need for liquidity assurances in domestic and international financial markets. The recent Asian financial crisis and the financial fallout following the Russian debt moratorium in August 1998 have illustrated this dilemma only too clearly.

\section{Credit rationing and contagion in the IIBM}

\subsection{Origins of credit rationing in the IIBM}

It has for some time been well understood, if not sufficiently appreciated by policymakers, that the prime characteristic of the IIBM is the predominance of quantity credit rationing. The price of interbank credit typically does not adjust to clear the market. Rather, what has typically been observed is modest or little differentiation in the price of credit but the use of informal, normally stable credit lines to borrowers. ${ }^{10}$ The deficiency of pricing according to counterparty risk is argued to have led to

9 Bhattacharya and Fulghieri (1994) consider a variant of this model which shows that the difficulty of interbank coordination can result in distortions in the maturity of investments by banks.

10

On the predominance of credit rationing in the IIBM see Giddy (1981), Dean and Giddy (1981), Clarke (1983), Moffett (1986) and Van Roij (1989). Moffett (1986) argues that the international interbank market is probably the financial market whose form of credit rationing is most similar to the theoretical model proposed by Stiglitz and Weiss (1981). 
excessive dependence on central banks during periods of crises (Giddy (1981)). The 1983 BIS G10 central bank study (the "Holland Report") noted that "The greater risk of lending to some banks may be reflected in a premium which they pay as well as in the size of the lines granted to them.... These premiums are typically modest, with most banks in normal circumstances paying no more than perhaps $1 / 16$ to $1 / 4$ percent" (p. 33). ${ }^{11}$ Except in periods of serious financial fragility, as in recent years in the periodic emergence of the "Japan premium", credit rationing with only modest differentiation in price prevails in the IIBM.

An example of the modest amount of price differentiation in the interbank market can be seen in Chart 1, showing the 12-month offer rates for yen- and dollar-denominated contracts for four Japanese banks. From 1995 to late 1997 all four banks paid almost identical rates for one-year yen interbank funds. After November 1997 a spread opened, with Bank of Tokyo-Mitsubishi (BOTM), considered one of the most creditworthy Japanese banks, paying the lower rate. The chart confirms that for noncrisis periods there is often little price discrimination in the IIBM. ${ }^{12}$

We also observe that up until late 1997 there was little difference between rates paid for 12-month US dollar interbank funds by Citibank, Bank of Tokyo-Mitsubishi and Sumitomo Bank, seen in Chart 2. Only after the outbreak of the Asian crises did rates start to differ significantly from one another. However, by the spring of 1999 the spread between them closed, even though the credit ratings continued to differ.

Credit rationing may result from at least two sources: adverse selection and moral hazard. Adverse selection arises when higher loan rates may cause some potentially creditworthy borrowers of a given risk class to drop out of the loan market, thus increasing the aggregate credit risk of the remaining pool of potential borrowers. As lenders are often assumed to be unable to perfectly distinguish between different classes of borrowers due to imperfect information, in some cases they may offer a similar loan contract to all borrowers of a given risk class but limit the quantity of credit to each. Credit rationing may also occur as a result of moral hazard, the inability of the lender to exercise some control over the use of the credit granted to the borrower. In both cases the result will be a backward bending supply curve for credit, implying that at some point the expected return to the lender declines as the loan rate rises; after this point, the quantity of credit supplied falls with further increases in interest rates.

11 The credit rationing by banks as a result of imperfect information and the inability of banks to use interest rates to clear the market for lending to developing countries was noted in the early 1980s. See Bacha and Diaz Alejandro (1982). These authors noted the "irrationally low" spreads and fees on bank loans to some developing countries.

Peek and Rosengren (1998) provide a careful analysis of the rates paid for eurodollar and euroyen interbank funds in Japan. Prior to the failure of Yamaichi Securities in 1997 they report a difference of little more than a few basis points in rates paid by Japanese banks despite significant differences in credit ratings. 
Chart 1

Japanese banks

12-month offered rates for US\$-denominated contracts

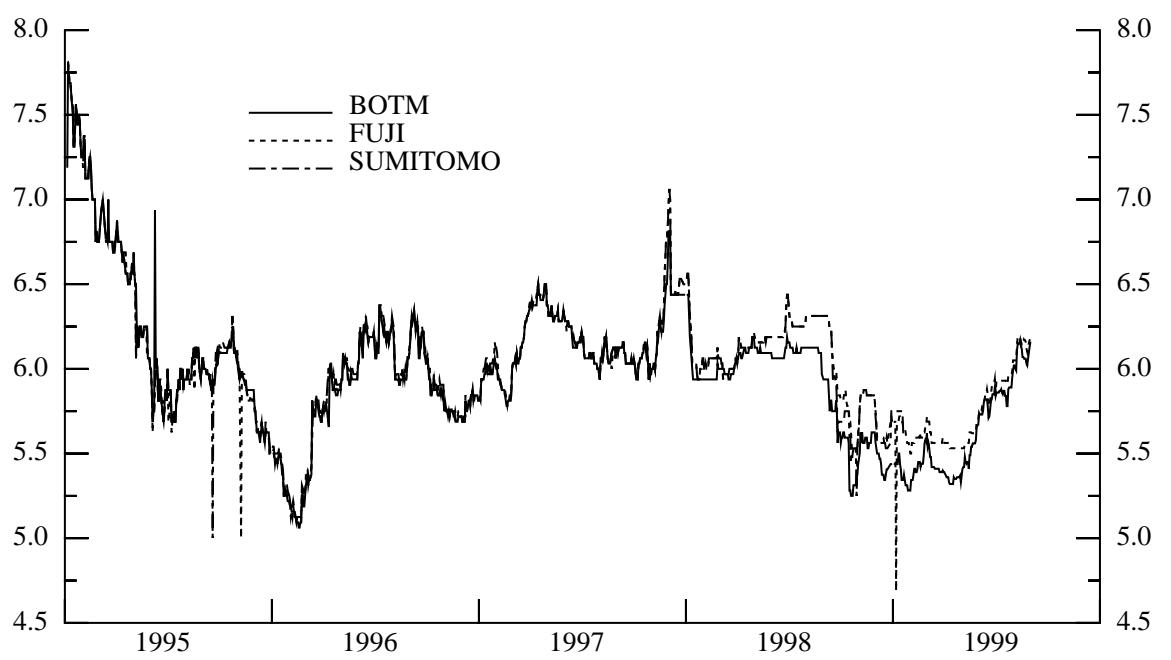

12-month offered rates for Yen-denominated contracts

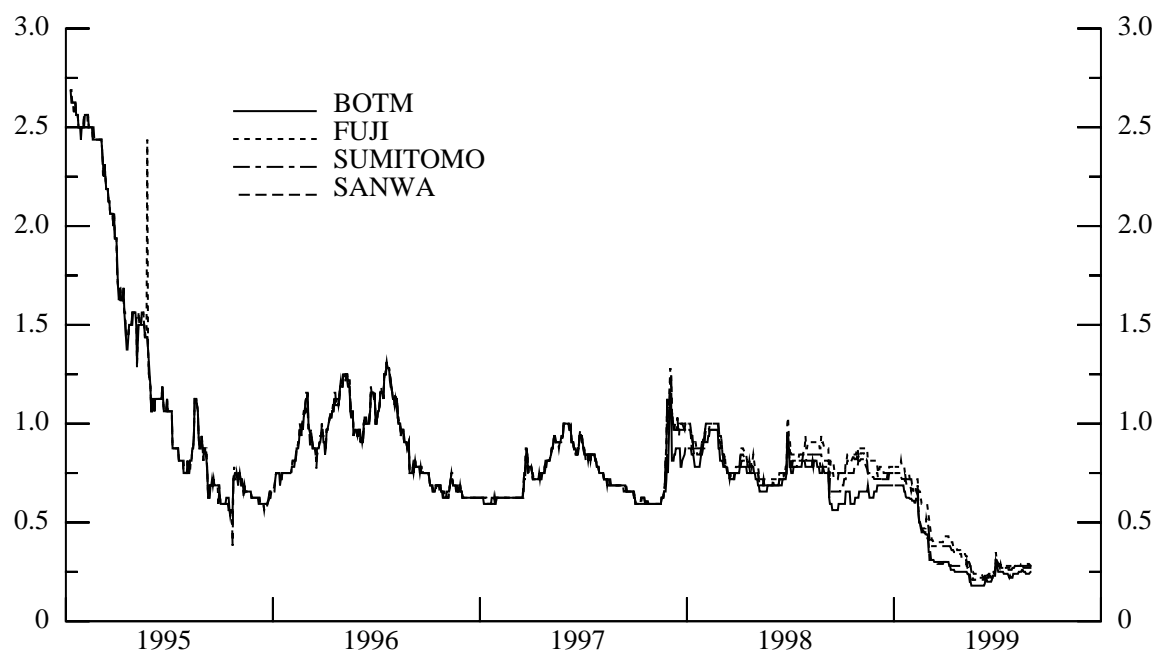

Sources: BLOOMBERG

MED Research Group, HJB / 22.02.2000 at 16:32 / Function: JRB9909-JPGRAPH 
Chart 2

Japanese and US banks

12-month offered rates for US\$-denominated contracts

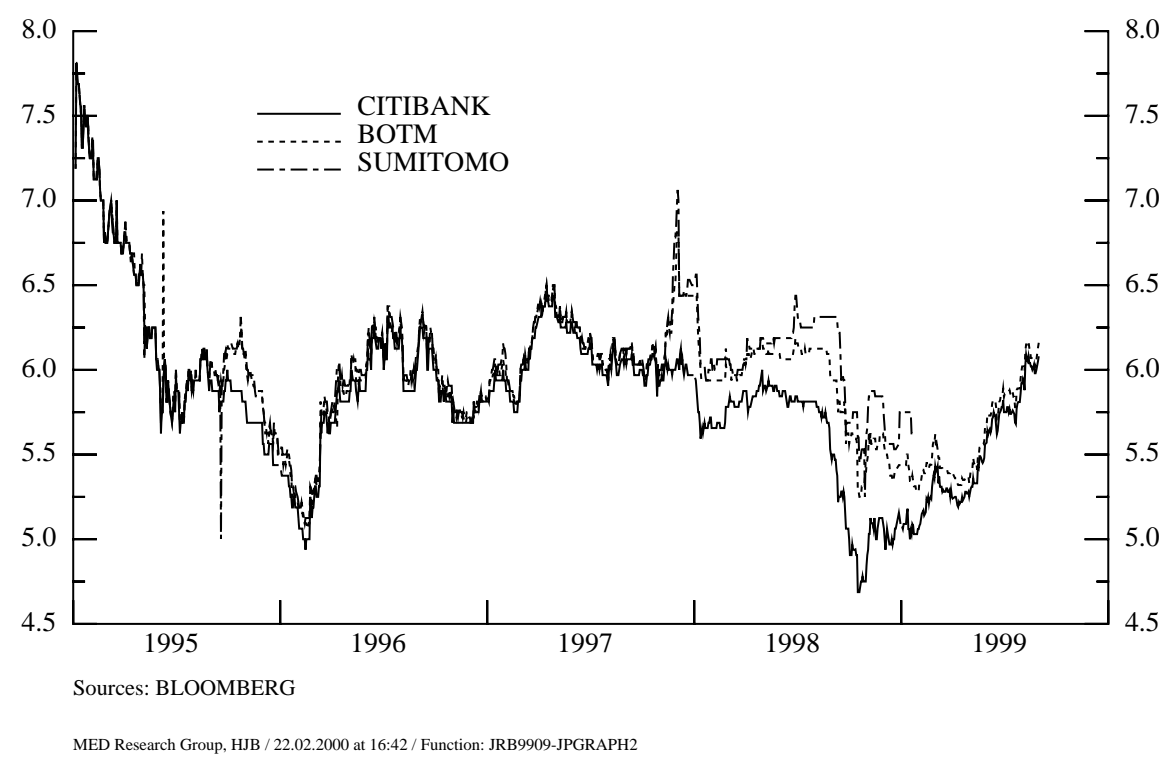


The lack of certain information of creditors on borrowers can be theoretically shown to explain several aspects of loan contracts used in developing country lending. Kletzer (1984) describes how asymmetric information regarding the total indebtedness of developing country borrowers can lead to short debt maturity structures, more bank than bond financing, and a relationship between quantity credit rationing and rates of investment. Short maturity debt contracts are a simple consequence of the absence of enforceable constraints on debt dilution. The risk of debt repudiation in developing countries leads directly to quantity credit rationing. In contrast, in countries with enforceable loan covenants and transparent bankruptcy procedures interest rates can adjust to clear the loan market.

The IIBM is different from other international financial markets in part because of the enormous amount of unsecured lending and, in many cases, due to the deficiency of information on the true quality of borrowers and their behaviour. These characteristics make it ripe for allocation by rationing. It has been suggested that rationing might be eliminated by banks screening applicants by simultaneously offering both loan rates and collateral requirements (Bester (1985)). (Good borrowers would then prefer lower rates and greater collateral given their lower probability of potential default.) While there is theoretical debate surrounding this argument, it may help explain the rapid growth in instruments such as RPs in recent years. ${ }^{13}$

Other arguments can be provided which would lead to credit rationing in the international interbank loan market. ${ }^{14}$ However, the primary reason for the high degree of credit rationing appears to be the limited information on counterparties. The 1992 BIS G10 central bank study of the changing structure of international interbank relations explicitly noted that "credit risks are not fully incorporated in the pricing of interbank products, ... given the lack of complete information." It was argued that this is especially true of markets where brokering is common (to varying extents in the deposit, FX spot, short-term forward and options, and FRA markets), and where prices must be taken as given. ${ }^{15}$

This lack of complete information on counterparties would imply that adverse selection rather than, strictly speaking, moral hazard (in the narrow sense of the inability to influence the activities of the borrower) is the major reason for credit rationing in the IIBM. However, it should also be noted that in some cases there is little difference in rates paid for international interbank borrowing even where there have been considerable well-known differences in credit quality. Peek and Rosengren (1998) report that during 1995 and 1996 Libor quotes for major Japanese banks for eurodollar and euroyen

13 With regard to the debate regarding credit rationing and collateral, see Jaffee and Stiglitz (1990).

The origin of the popular version of credit rationing is Stiglitz and Weiss (1981), who built on work by Jaffee and Russell (1976). See Jaffee and Stiglitz (1990) and Freixas and Rochet (1997) for a good discussion of credit rationing.

15 It is arguable whether brokered markets would increasingly lead to less reflection of credit risk in lending rates. In the United States brokered deposits (CDs) are common, with CD rates reflecting expected credit risks. Ellis and Flannery (1992) found that CD rates for six large US money centre banks appeared to capture a risk premium related to available public information. 
borrowing rarely differed by more than a few basis points, even though there were substantial differences in their credit ratings provided by the major rating agencies.

The existence of widespread credit rationing in the IIBM resulting from "the scarcity of information about the quality of the assets of institutions' activities in the market" (Clarke (1983), p. 30) has been emphasised since the early growth of the euromarkets. Giddy (1981) and Clarke (1983) both pointed to the widespread assumption that if banks participating in the market got into trouble, they would be supported by their central banks. This widespread and firmly held assumption led to an "insouciance" about available information on counterparties, which, according to Clarke (1983) "tends to infect the whole market". Indeed, Clarke suggests that in the past inquiries about counterparties' balance sheets were considered to be in "rather bad taste". The obvious question is whether the assumption of official support in time of stress was the cause of the information insouciance of the major players in the interbank market. $^{16}$

The limited credit allocation by price in the IIBM and the assumption of likely official support has aroused concern among some economists that central banks were confronting a sizeable contingent credit risk. Ian Giddy's early comments regarding the functioning of the interbank eurocurrency market and the implications of credit rationing look prescient in the light of the recent Asian financial crisis:

"Indeed, if it is true that the market places great store on central bank support, it will continue to grant credit without discrimination to large banks. In effect the market will test central banks' mettle, and if ever the rule of central bank rescues is broken, severe credit rationing will occur." 17

The degree of severe curtailment and rationing of bank credit which can take place due to information asymmetries can be seen in the private lending flows to emerging market economies. Table 1, compiled by the Institute for International Finance, shows the dramatic reduction in commercial bank flows to emerging market countries between 1996 and 1998. Of the total reduction in net private flows of $\$ 184.4$ billion, $\$ 148.7$ billion was from commercial bank lenders. As will be seen later, most of the reduction in commercial bank credit was in the form of sharp declines in interbank deposit flows.

One question which hangs over much of this paper is why there is not greater differentiation in the price of credit among borrowers in the IIBM. Certainly elements of information imperfections and uncertainly regarding the investment activities of foreign borrowers contribute to the credit rationing behaviour of the market. Yet other financial markets, such as the US federal funds and negotiable CD markets, also suffer from information asymmetries. But in these markets we sometimes observe

\footnotetext{
16 The assumption of implicitly guaranteed cross-border interbank deposits is emphasised in the recent work on the Asian crisis by Corsetti, Pesenti and Roubini (1999).

17 Giddy (1981), p. 184.
} 
significant "tiering", with the large money centre banks paying less than smaller regional banks. The credit rationing which occurs in the federal funds market usually applies to small banks, where information problems are greatest. ${ }^{18}$ The international interbank market appears to function much differently than domestic interbank markets.

Table 1

Emerging market economies' external finance

\begin{tabular}{|c|c|c|c|c|c|}
\hline & 1995 & 1996 & 1997 & $1998 \mathrm{e}$ & $1999 f$ \\
\hline Current account balance & -85.1 & -96.1 & -76.8 & -19.4 & -27.7 \\
\hline External financing, net & 269.7 & 332.4 & 299.5 & 194.1 & 174.4 \\
\hline Private flows, net & 228.8 & 327.7 & 262.8 & 143.3 & 140.9 \\
\hline Equity investment & 105.7 & 129.0 & 141.8 & 122.9 & 124.8 \\
\hline Direct equity & 81.3 & 93.3 & 116.1 & 120.4 & 103.3 \\
\hline Portfolio equity & 24.4 & 35.7 & 25.7 & 2.4 & 21.5 \\
\hline Private creditors & 123.1 & 198.6 & 121.0 & 20.4 & 16.1 \\
\hline Commercial banks & 98.7 & 119.7 & 32.0 & -29.0 & -11.8 \\
\hline Non-bank private creditors & 24.4 & 78.9 & 89.0 & 49.4 & 27.9 \\
\hline Official flows, net & 40.9 & 4.7 & 36.7 & 50.8 & 33.5 \\
\hline International financial institutions & 20.7 & 7.0 & 28.3 & 35.3 & 19.1 \\
\hline Bilateral creditors & 20.3 & -2.3 & 8.4 & 15.5 & 14.3 \\
\hline Resident lending/other, net* & -90.4 & -153.0 & -181.8 & -134.1 & -94.6 \\
\hline Reserves excl. gold (- = increase) & -94.3 & -83.5 & -42.8 & -39.7 & -52.1 \\
\hline
\end{tabular}

\subsection{Changing perceptions of bank credit risk}

It can be argued that during the 1990s in both industrial and emerging market countries a number of the major banks have been perceived as "less risky" than they were during the 1980s. This perception may be partly due to improved fundamentals and in part the result of the abundance of available international liquidity.

18 Allen and Saunders (1986) construct a model of the federal funds market based on information asymmetries between buyers and sellers of funds to understand why smaller banks typically pay higher rates or are rationed out of the market. They show that there is a rationing point which differentiates those banks which can borrow funds from those which cannot. This rationing point is a function of the cost to a bank of signalling its true default risk. They describe how the viability of the federal funds market depends on a particular solution to the adverse selection problem, this solution being the creation of implicit multi-period contracts between buyers and sellers of funds. In the context of the IIBM it may be the case that the high cost of signalling accurate default risk would exclude many borrowers from the market. This problem might only be overcome by the government signalling implicit guarantees for the interbank liabilities of the borrowing bank. 
Chart 3

\section{United States: spreads on three-month instruments}

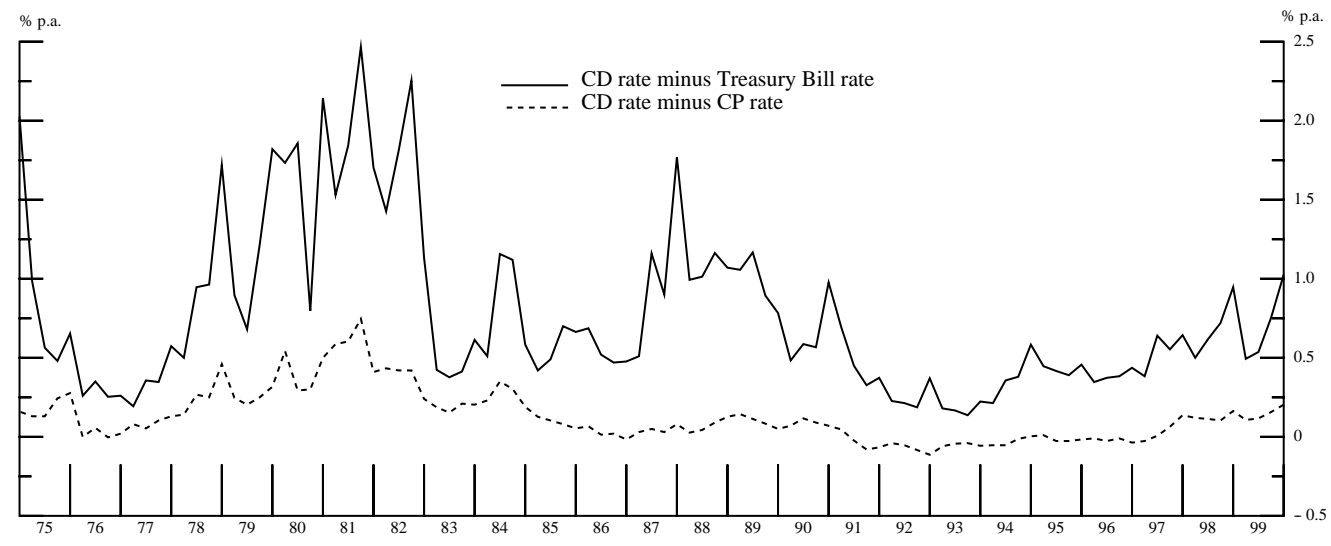

Difference between interbank offered rates (3-month claims) in Tokyo and London, 1997-99

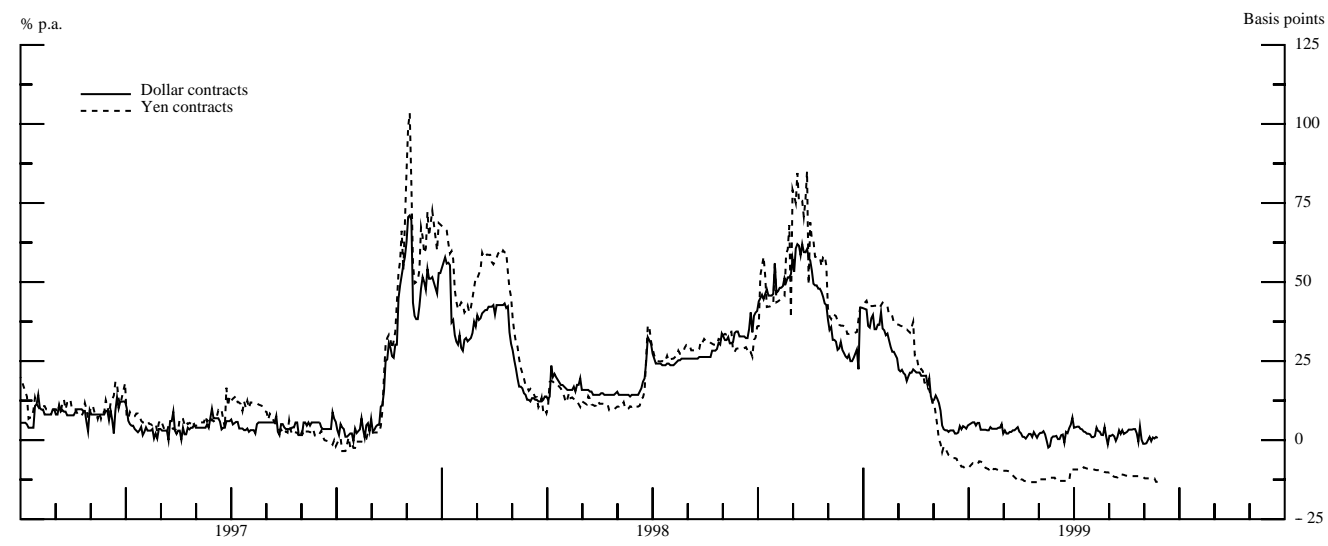

Stock market index for Japanese bank shares, 1997-99

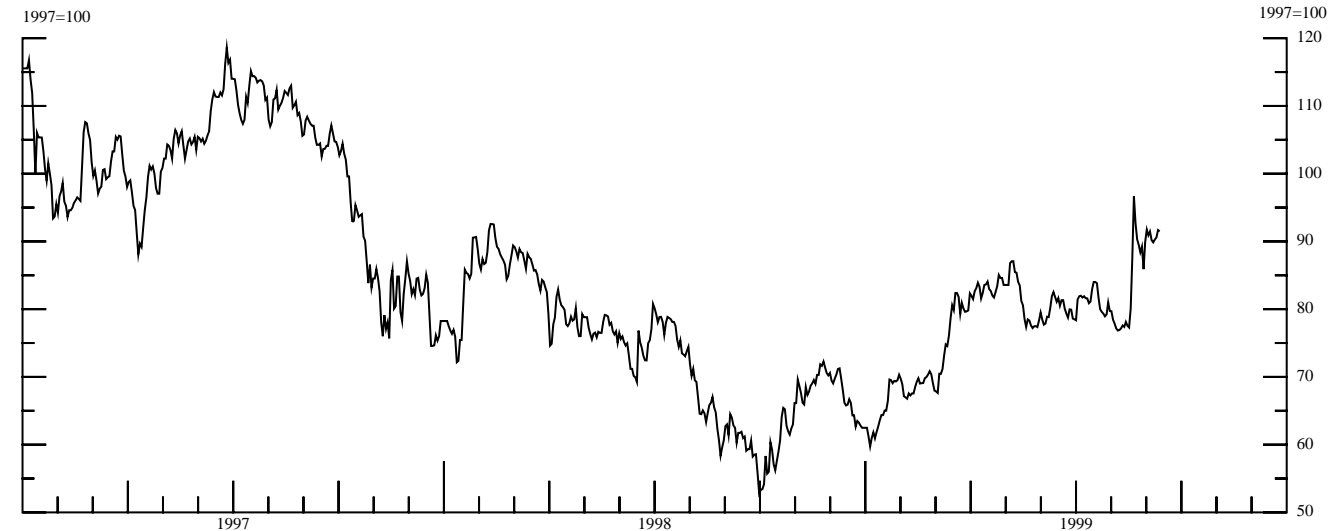

Sources: BIS, National sources, DRI, Datastream.

MED Research Group, HJB / 01.02.2000 at 15:06 / Function: JRB9909-USSPRJPREM 
Chart 4

Stock market index of banks and risk spreads

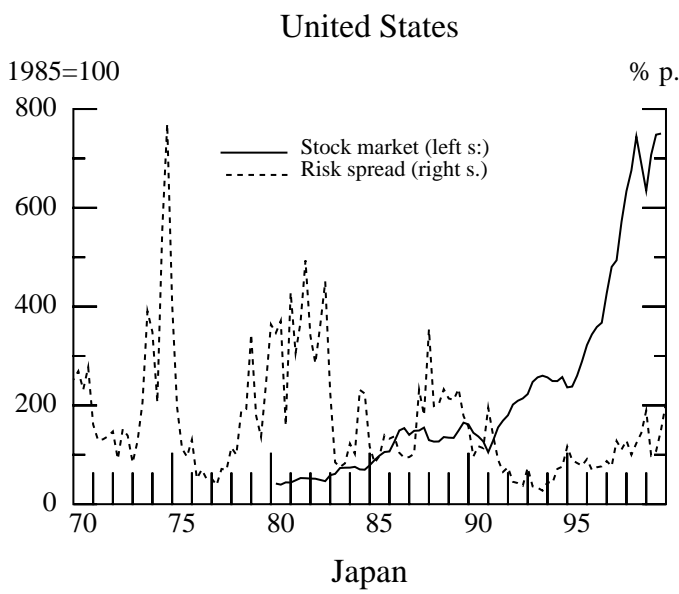

\section{United Kingdom}

p.a. $1985=100$

$4 \quad 1500$

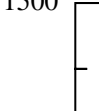

$-$

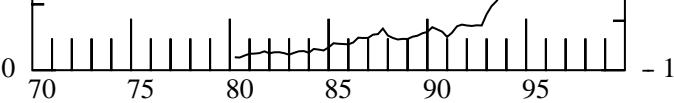

$1985=100 \quad \%$ p.a. $1985=100$

Germany
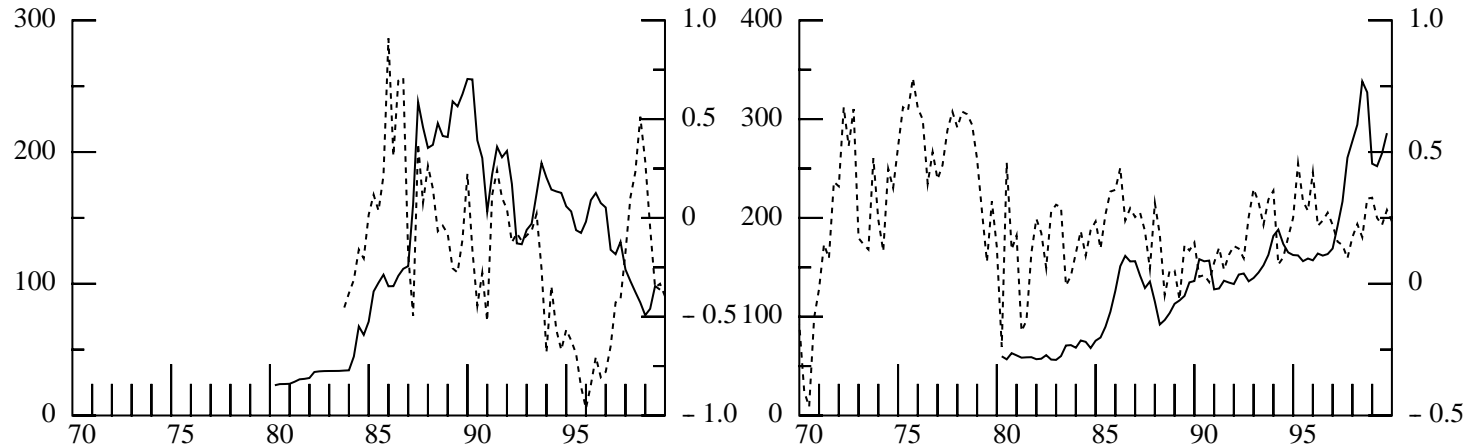
For the United States we base this statement on the comparison of bank CD rates with rates on shortterm government securities and corporate prime commercial paper. As seen in Chart 3, the spread between three-month $\mathrm{CD}$ rates and three-month Treasuries has been considerably lower and more stable than during the 1980s. Similar to the experience in the United States, we observe a persistent decline in the United Kingdom in the spread between UK bank CD rates and short-term government interest rates. Again similar to the US experience, prices for bank shares skyrocketed during the 1990s (Chart 4).

Japan has obviously undergone severe difficulties in its financial system. However, an anomaly appears if we compare the so-called "Japan premium", the difference between Japanese bank borrowing rates in London and Tokyo on US dollar and Japanese yen contracts, with the Tokyo index of Japanese bank shares, seen in Chart 3. The premium fluctuated around zero in the second half of the 1980s when Japanese bank share prices were quite strong. It rose in the first half of the 1990s as bank share prices weakened. However, although the premium periodically rose dramatically starting in 1997 and bank shares continued to weaken, the sizeable decline in the premium since mid-1998 appears inconsistent with weak bank equity prices. The premium was obviously influenced by government assistance to a troubled banking industry. ${ }^{19}$

A persistent decline in the spread between bank short-term borrowing rates and similar maturity government rates can be partly explained by the assumption that certain governments may be increasingly absorbing part of the credit risk facing their banking systems. That is, in some countries bank deposits are arguably perceived as less risky because there is currently a greater explicit or implicit government guarantee of their repayment than earlier. This perception appears to be prevalent in the IIBM. The argument that there are strong implicit guarantees in the international interbank market has been made by Giddy (1981), Clarke (1983), Guttentag and Herring (1985) and FolkertsLandau (1985), among others. Recently Herring (1999) noted the "breath-taking speed" with which, during the recent South Korean financial crisis, "IMF funds flowed through the central banks to foreign banks". Goldstein (1998) also has emphasised the urgent need to reduce the moral hazard resulting from guarantees and financial support to large uninsured private creditors, using South Korea as a recent illustration of the problem.

If the argument that international interbank deposits are increasingly perceived to be assured of repayment is correct, it would imply that the potentially most competent monitors of banks, namely their competitors, are encouraged to lend freely into the IIBM without serious analysis of counterparty

19 This argument is supported by the careful analysis of the Japan premium by Peek and Rosengren (1999). 
risk. ${ }^{20}$ The perception that interbank lending is less risky than lending to non-bank institutions is supported by capital requirements: both before and after the imposition of common risk-based bank capital requirements established in 1988 by the G10 countries, the capital charge against lending to banks was lower than that on credits extended to non-banks. Indeed, in the 1988 Capital Accord the risk weight on short-term interbank lending was set lower than that for lending to non-OECD governments. $^{21}$

The perception that some of the internationally large banks are now perceived as being of better credit quality, relative to governments, than they were in the 1980s conflicts squarely with the fact that many fewer banks currently receive the highest ratings available from the major credit rating agencies (See Chart 5). This seemingly contradictory evidence may be understood if international interbank deposits are assumed to be "special". Central banks might be viewed by the international banking community as being very reluctant to see a serious disruption in the IIBM because of the risk of contagion in this market.

\section{Chart 5}

Individual credit rating of major banks *
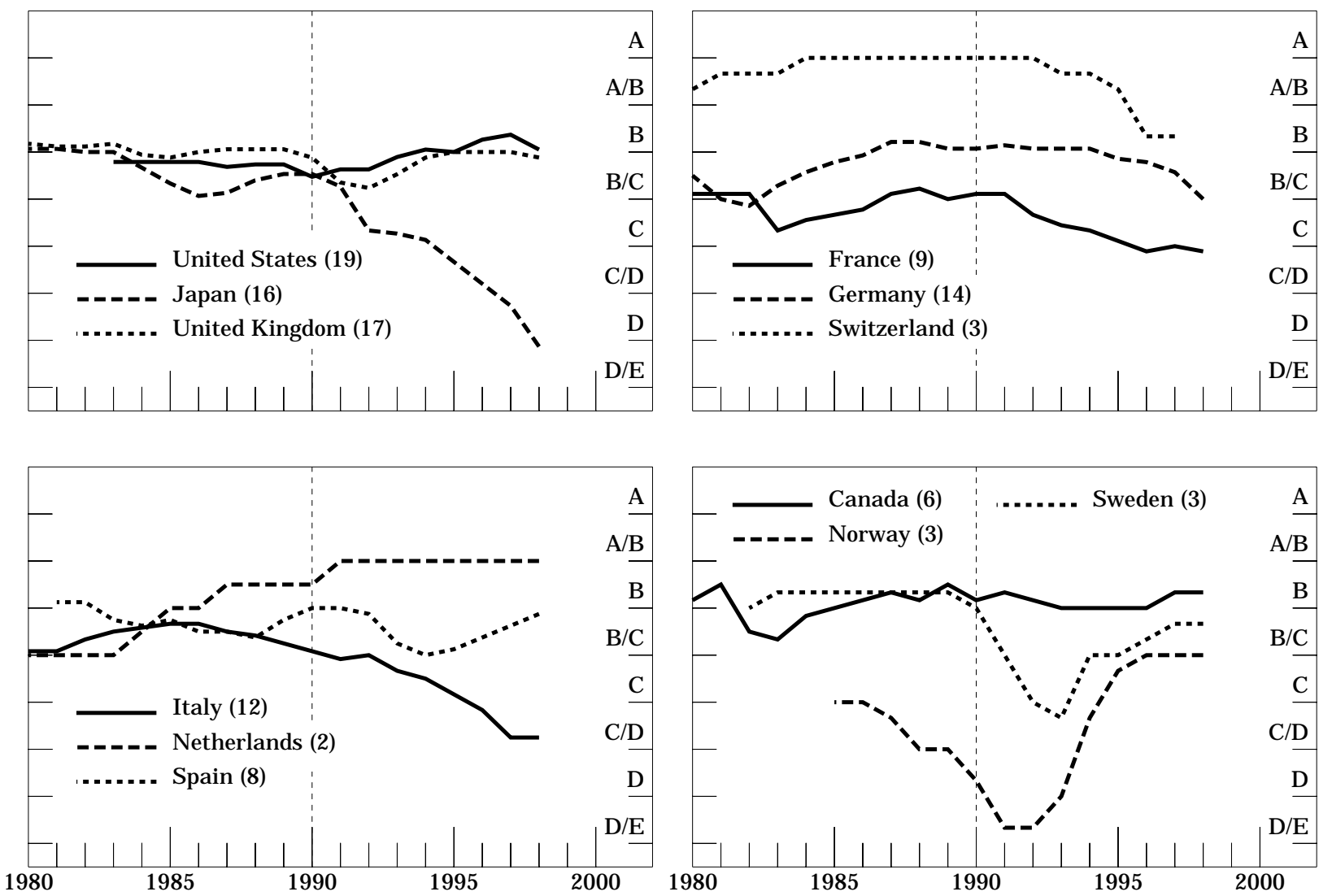

* Average of banks' rating at end-year. Figures in brackets indicate the number of banks included. Sources: Fitch IBCA; authors' calculations.

20 See Rochet and Tirole (1996) on this point.

21 Guttentag and Herring (1985) noted the lower capital requirements for interbank lending in several major countries before the 1988 Capital Accord. 
An indication of the implicit guarantee which may exist in the interbank market can be obtained by considering the so-called bank "support ratings" given by major credit rating agencies. Support ratings can be thought of as a credit rating agency's assessment of the likelihood of the government coming to the assistance of a bank in difficulty. Support ratings for the period 1992 to 1998 were provided by the bank credit rating agency IBCA. The IBCA ratings were converted into a scale from one to nine, with nine indicating the highest assurance of government support. Average IBCA support ratings can be seen in Table 2 for several developing countries and Japan.

Table 2

Consolidated asset-weighted average of IBCA support ratings for selected countries' banks*

\begin{tabular}{|c|c|c|c|c|c|c|c|}
\hline & 1992 & 1993 & 1994 & 1995 & 1996 & 1997 & 1998 \\
\hline Asia excluding Japan & 8.00 & 8.00 & 8.00 & 8.00 & 7.87 & 7.15 & 7.42 \\
\hline Latin America & 4.05 & 7.13 & 6.36 & 6.16 & 5.78 & 6.10 & 6.26 \\
\hline \multicolumn{8}{|l|}{ Asia } \\
\hline Korea & n.a. & 8.00 & 8.00 & 8.00 & 8.12 & 7.20 & 8.00 \\
\hline Thailand & n.a. & n.a. & n.a. & n.a. & 8.00 & 6.34 & 5.78 \\
\hline Malaysia & 8.00 & 8.00 & 8.00 & 8.00 & 8.00 & 7.21 & 7.50 \\
\hline Indonesia & n.a. & n.a. & n.a. & n.a. & 4.00 & 5.63 & 1.00 \\
\hline Philippines & n.a. & n.a. & n.a. & n.a. & n.a. & 7.00 & 7.00 \\
\hline Japan & 8.52 & 8.52 & 8.52 & 8.53 & 8.60 & 8.38 & 8.00 \\
\hline \multicolumn{8}{|l|}{ Latin America } \\
\hline Brazil & 4.0 & 7.09 & 6.79 & 6.35 & 6.27 & 6.50 & 6.53 \\
\hline Argentina & n.a. & 4.41 & 3.00 & 3.00 & 3.75 & 3.00 & 3.79 \\
\hline Chile & n.a. & n.a. & n.a. & 8.00 & 7.12 & 7.37 & 8.00 \\
\hline Venezuela & 4.86 & 6.90 & 3.00 & 3.00 & 3.00 & 3.29 & 3.93 \\
\hline Columbia & n.a. & n.a. & n.a. & n.a. & 3.00 & 3.00 & 3.32 \\
\hline
\end{tabular}

What is clear from Table 2 is the perception of substantial contingent government support for banking systems in Asian countries, particularly Japan, Korea, Thailand and Malaysia. The weighted average support ratings are much lower for Latin American countries. The weighted average rating for the region "Asia excluding Japan" (including many more countries than those shown in the table) was around 8.0 for the period 1992 to 1995 with a modest decline in 1996, all years when Asian countries were large borrowers in the IIBM. We also note the very high support ratings given Japanese banks, which are higher than for any other country shown in the table.

Evidence of market perceptions of improved credit quality of emerging market economies is contained in lending spreads. Spreads fell significantly in Latin America from mid-1995, after the Mexican peso crisis erupted, to the third quarter of 1997 (Table 3). While the decline in spreads was impressive, it is 
debatable whether they truly represented an improvement in the credit risk in emerging market lending. Cline and Barnes (1997) estimate that the decline in spreads is indeed difficult to justify statistically on the basis of improved fundamentals. Their statistical analysis indicates that less than half of the decline in spreads for 14 emerging market countries can be explained by the improved fundamentals. ${ }^{22}$ What accounts for the unusual decline in spreads appears to be related to the plentiful, if not excessive, supply of international liquidity. An additional factor contributing to the decline in spreads may arguably have been the perceived expansion in the implicit international safety net extended to very large borrowing countries, following the concerted rescue package provided to Mexico a few years earlier. ${ }^{23}$

Table 3

Bond spreads in Latin America and Asia ${ }^{1}$

\begin{tabular}{|c|c|c|c|c|c|c|c|c|c|c|}
\hline & \multicolumn{3}{|c|}{ Asian crisis } & \multicolumn{3}{|c|}{ Russian crisis } & \multicolumn{3}{|c|}{ Brazilian crisis } & \multirow{2}{*}{$\begin{array}{c}\text { Latest } \\
23-27 \\
\text { Aug. } \\
1999\end{array}$} \\
\hline & $\begin{array}{c}1995 \\
\text { Q3 }\end{array}$ & $\begin{array}{c}1997 \\
\text { Q3 }\end{array}$ & $\begin{array}{c}\text { Differ- } \\
\text { ence }\end{array}$ & $\begin{array}{c}3-7 \\
\text { Aug. } \\
1998\end{array}$ & $\begin{array}{l}7-11 \\
\text { Sept. } \\
1998^{2}\end{array}$ & $\begin{array}{l}\text { Differ- } \\
\text { ence }\end{array}$ & $\begin{array}{c}1-4 \\
\text { Dec. } \\
1998\end{array}$ & $\begin{array}{c}11-15 \\
\text { Jan. } \\
1999^{3}\end{array}$ & $\begin{array}{c}\text { Differ- } \\
\text { ence }\end{array}$ & \\
\hline Argentina & 6.9 & 1.9 & -5.0 & 2.7 & 9.7 & 7.0 & 5.6 & 6.3 & 0.7 & 5.3 \\
\hline Brazil & n.a. & n.a. & n.a. & 5.7 & 14.2 & 8.5 & 9.1 & 13.5 & 4.4 & 8.3 \\
\hline Chile & 4.0 & 1.2 & -2.8 & 2.3 & 3.0 & 0.7 & 3.7 & 3.5 & -0.2 & 3.0 \\
\hline Colombia & 2.2 & 1.4 & -0.8 & 3.3 & 8.9 & 5.7 & 6.5 & 6.7 & 0.2 & 6.4 \\
\hline Mexico & n.a. & n.a. & n.a. & 3.6 & 7.8 & 4.2 & 5.1 & 5.5 & 0.5 & 4.2 \\
\hline Peru & n.a. & 1.9 & n.a. & 3.8 & 7.8 & 4.0 & 5.0 & 5.8 & 0.8 & 5.3 \\
\hline Venezuela & n.a. & 2.8 & n.a. & 5.9 & 17.0 & 11.1 & 10.3 & 10.0 & -0.3 & 9.5 \\
\hline Indonesia & $1.2^{4}$ & 1.4 & 0.2 & 7.8 & 8.0 & 0.2 & 8.9 & 9.9 & 1.0 & 6.1 \\
\hline Korea & $0.7^{5}$ & 1.0 & 0.3 & 4.2 & 8.2 & 4.0 & 5.1 & 4.2 & -0.8 & 2.2 \\
\hline Malaysia & $0.6^{4}$ & 0.8 & 0.2 & 4.1 & 10.3 & 6.3 & 9.5 & 9.2 & -0.2 & 2.8 \\
\hline Thailand & n.a. & 1.5 & n.a. & 4.3 & 8.5 & 4.2 & 3.4 & 3.2 & -0.1 & 2.0 \\
\hline
\end{tabular}

While there no doubt was an increased concern with counterparty credit risk in the early 1990s, as noted in the Promisel Report (BIS (1992)), there appears also to have been an increased perception of contingent government support for a number of large internationally active banks. This perception was combined with much more than ample international liquidity which drove country risk spreads down to abnormally low levels. These two factors arguably offset to some extent the earlier concern with

22 Cline and Barnes (1997) estimate that as of the second quarter of 1997 eurobond spreads of emerging markets were around 115 basis points lower than was predicted by the relationship between spreads and fundamentals which prevailed from 1992 to 1996.

23 Zhang (1999), on the other hand, argues that the support package given Mexico did not create a moral hazard in emerging market lending. 
international interbank market credit risk, resulting in large short-term foreign currency exposures for banks in a number of emerging market countries.

\subsection{Recent behaviour of international interbank activity: the liquidity valve}

One of the most notable and to a degree unexpected events in international interbank deposit activity during the decade was its remarkable growth. Interbank deposit activity started the 1990s by first displaying an abrupt slowdown (Charts 6 to 8 and Tables 4 and 5). This continued up to 1992, after which growth resumed at a surprisingly rapid pace until the crisis erupted in Asia in 1997.

The initial slow growth in international interbank deposit activity at the beginning of the 1990s was attributed in part to the rather weak economic performance in the major industrial economies. This was also believed to be a result of the greater use of derivatives to hedge market risk, substituting for interbank deposit activity. The greater concern with counterparty credit risk was also given as an explanation for the modest growth in aggregate cross-border lending, including lending to banks. ${ }^{24}$

Around 1994 international interbank deposit activity picked up at a surprisingly fast pace. Rather than the expected slowdown, we witnessed a flurry of interbank deposit lending, particularly, given the economic size of the region, where deposit-taking had previously been rather modest, namely in Asia.

Before discussing the available data on international interbank deposit activity we should recall the earlier concerns that economists have expressed regarding cross-border interbank lending. Herring (1985), Guttentag and Herring (1985, 1986), Giddy (1981) and Dean and Giddy (1981) had all made note of the efficiency enhancing role of the IIBM in allocating international liquidity and facilitating interest rate and exchange rate risk management. At the same time, they and others expressed concern that the market could also lead to banks taking excessive risks with the greater availability of liquidity. The market could become equally efficient in distributing financial shocks around the globe, which in its absence would have remained localised. These risks were argued to result from the credit rationing behaviour of the market and assumption of official intervention to support it in periods of stress. ${ }^{25}$

It should be noted that relatively little empirical work has been conducted analysing the determinants of international interbank deposit activity, even though international interbank assets account for a large percentage of total foreign assets for many countries. Moshirian and Bishop (1997) estimate that

24 See Bank for International Settlements (1992).

25 Giannini (1999) and Bisignano (1999) both draw attention to the major growth in international interbank lending to emerging market countries in Asia in the 1990s and the possible role played by implicit government guarantees. The contribution of implicit guarantees is also noted in an official review of the supervisory lessons to be drawn from the Asian crisis. See Bonte et al. (1999). 


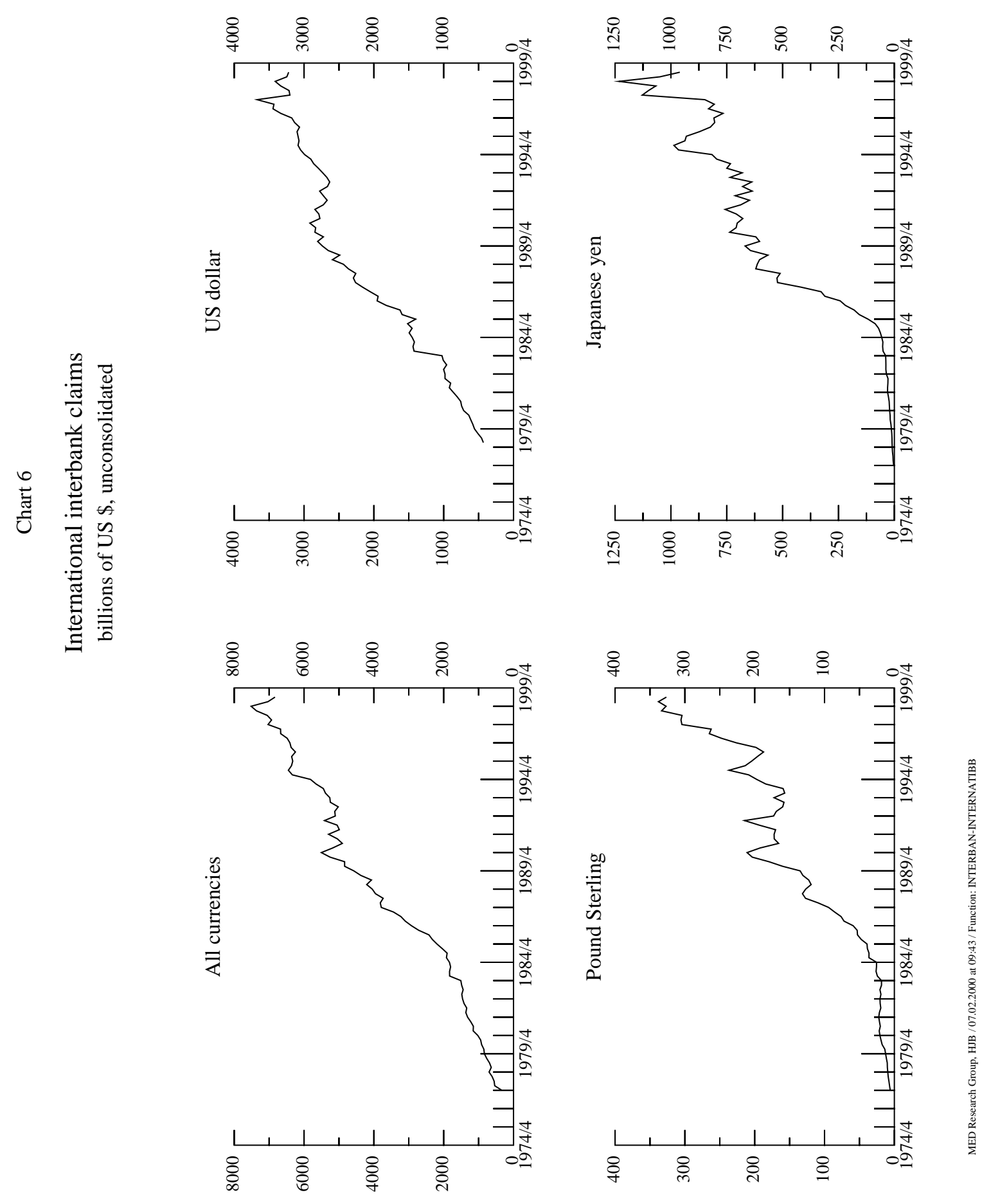


Chart 7

International interbank claims in all currencies Amounts outstanding, billions of US \$
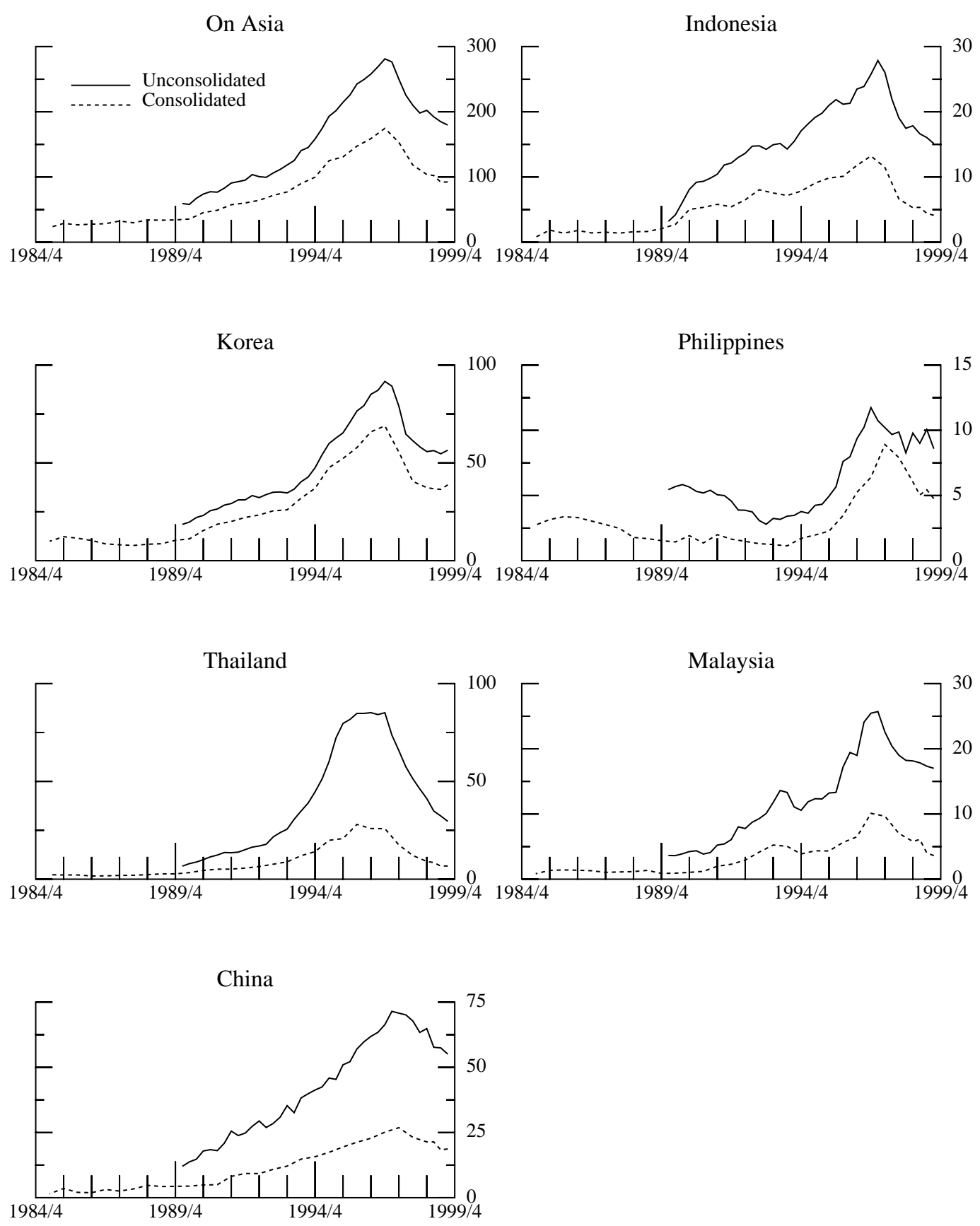

MED Research Group, HJB / 07.02.2000 at 09:44 / Function: INTERBAN-INTERNATIB4B 
Table 4

The interbank market within the BIS reporting area

In billions of US dollars

\begin{tabular}{|c|c|c|c|c|c|c|c|c|c|c|c|}
\hline \multirow{4}{*}{$\begin{array}{l}\text { Cross-border interbank claims } \\
\text { of which: } \\
\text { Between Japan and other inside area } \\
\text { countries }\end{array}$} & \multicolumn{6}{|c|}{ Average annual changes at constant end-of-quarter exchange rates } & \multicolumn{5}{|c|}{ Stocks at end of period at current exchange rates } \\
\hline & $1984-86$ & $1987-88$ & $1989-90$ & $1991-96$ & 1997 & 1998 & 1983 & 1987 & 1991 & 1995 & 1998 \\
\hline & 238.2 & 417.4 & 435.8 & 106.1 & 799.4 & 297.3 & $1,169.8$ & $2,752.3$ & $4,135.6$ & $4,951.6$ & $5,880.1$ \\
\hline & 113.9 & 322.9 & 156.9 & -66.6 & 196.1 & -78.5 & 160.3 & 949.7 & $1,460.1$ & $1,445.5$ & $1,340.7$ \\
\hline $\begin{array}{l}\text { Between the United States and other } \\
\text { inside area countries except Japan }\end{array}$ & 46.4 & 39.3 & 82.6 & 28.7 & 225.8 & 73.7 & 386.0 & 617.8 & 816.4 & 915.5 & $1,257.6$ \\
\hline Between European countries & 54.4 & 47.4 & 150.4 & 122.1 & 309.6 & 334.7 & 341.7 & 754.8 & $1,368.6$ & $1,981.8$ & $2,593.5$ \\
\hline Other inside area & 23.5 & 7.8 & 45.8 & 21.9 & 67.9 & -32.5 & 281.7 & 430.0 & 490.6 & 608.9 & 688.2 \\
\hline Local foreign currency interbank claims & 49.0 & 34.2 & 55.6 & -0.8 & 49.3 & 31.7 & 324.2 & 603.2 & 621.9 & 722.6 & 609.7 \\
\hline Total international interbank claims & 287.2 & 451.6 & 491.4 & 105.4 & 848.7 & 329.0 & $1,494.0$ & $3,355.4$ & $4,757.5$ & $5,674.2$ & $6,489.8$ \\
\hline
\end{tabular}


Table 5

International bank positions by nationality of bank

Amounts outstanding, in billions of US dollars

\begin{tabular}{|c|c|c|c|c|c|c|c|c|c|c|c|c|}
\hline \multirow{3}{*}{ Parent country of bank } & \multirow{2}{*}{\multicolumn{3}{|c|}{ Total positions }} & \multicolumn{9}{|c|}{ Of which vis-à-vis } \\
\hline & & & & \multicolumn{3}{|c|}{ Related offices } & \multicolumn{3}{|c|}{ Other banks } & \multicolumn{3}{|c|}{ Non-banks $^{1}$} \\
\hline & 1983 & $1991^{2}$ & 1998 & 1983 & $1991^{2}$ & 1998 & 1983 & $1991^{2}$ & 1998 & 1983 & $1991^{2}$ & 1998 \\
\hline Total assets & $2,165.9$ & $6,137.0$ & $9,793.6$ & 502.6 & $1,755.2$ & $3,390.7$ & 944.8 & $2,538.7$ & $3,141.1$ & 718.5 & $1,843.1$ & $3,261.8$ \\
\hline Belgium & 38.2 & 135.1 & 251.8 & 2.0 & 8.5 & 15.2 & 18.0 & 77.8 & 121.7 & 18.2 & 48.8 & 114.9 \\
\hline Canada & 112.9 & 110.1 & 245.6 & 43.5 & 51.8 & 132.4 & 32.0 & 21.3 & 43.5 & 37.4 & 37.0 & 69.6 \\
\hline France & 191.4 & 565.4 & $1,017.5$ & 24.4 & 119.0 & 254.5 & 104.9 & 290.1 & 446.0 & 62.1 & 156.3 & 317.0 \\
\hline Germany & 144.5 & 640.4 & $1,792.1$ & 10.6 & 126.8 & 533.1 & 70.7 & 335.4 & 620.8 & 63.2 & 178.2 & 638.3 \\
\hline Italy & 80.9 & 397.5 & 475.4 & 2.3 & 42.9 & 65.3 & 57.7 & 187.4 & 228.6 & 20.9 & 167.1 & 181.5 \\
\hline Japan & 456.9 & $1,935.1$ & $1,823.2$ & 122.1 & 716.1 & 768.8 & 198.0 & 708.4 & 371.0 & 136.8 & 510.6 & 683.5 \\
\hline Luxembourg & 5.2 & 46.7 & 79.1 & 0.1 & 0.7 & 2.6 & 3.4 & 31.8 & 49.1 & 1.7 & 14.2 & 27.3 \\
\hline Netherlands & 62.5 & 199.5 & 525.0 & 5.4 & 31.1 & 179.8 & 35.4 & 99.9 & 143.3 & 21.7 & 68.5 & 201.9 \\
\hline Sweden & 18.2 & 128.9 & 104.9 & 0.9 & 20.5 & 29.2 & 5.8 & 18.0 & 36.0 & 11.5 & 90.4 & 39.7 \\
\hline Switzerland & 79.9 & 408.9 & 887.6 & 14.2 & 115.8 & 451.3 & 42.9 & 204.8 & 248.8 & 22.8 & 88.3 & 187.5 \\
\hline United Kingdom & 178.8 & 282.1 & 548.0 & 19.9 & 42.3 & 91.4 & 85.9 & 138.1 & 240.8 & 73.0 & 101.7 & 215.8 \\
\hline United States & 605.5 & 650.7 & $1,025.9$ & 227.0 & 363.9 & 610.1 & 205.0 & 141.1 & 160.9 & 173.5 & 145.7 & 254.9 \\
\hline Other & 191.0 & 636.6 & $1,017.5$ & 30.2 & 115.8 & 257.0 & 85.1 & 284.5 & 430.6 & 75.7 & 236.3 & 329.9 \\
\hline Total liabilities & $2,034.1$ & $6,095.8$ & $9,549.2$ & 484.3 & $1,662.4$ & $3,196.8$ & 936.6 & $2,473.0$ & $2,991.0$ & 613.2 & $1,960.4$ & $3,361.3$ \\
\hline Belgium & 38.6 & 133.1 & 257.7 & 2.3 & 7.1 & 18.8 & 25.2 & 84.8 & 131.5 & 11.1 & 41.2 & 107.4 \\
\hline Canada & 115.2 & 121.2 & 244.6 & 28.9 & 37.8 & 98.9 & 41.3 & 28.4 & 43.8 & 45.0 & 55.0 & 102.0 \\
\hline France & 185.8 & 630.4 & $1,042.1$ & 29.0 & 117.6 & 233.0 & 122.7 & 304.0 & 456.4 & 34.1 & 208.8 & 352.6 \\
\hline Germany & 131.7 & 489.2 & $1,769.5$ & 14.1 & 121.3 & 528.2 & 82.4 & 146.5 & 526.8 & 35.2 & 221.4 & 714.4 \\
\hline Italy & 78.9 & 427.5 & 457.0 & 4.7 & 41.9 & 66.9 & 65.8 & 287.2 & 279.0 & 8.4 & 98.4 & 111.1 \\
\hline Japan & 414.7 & $1,828.1$ & $1,318.7$ & 115.9 & 696.1 & 661.7 & 219.5 & 870.9 & 445.8 & 79.3 & 261.1 & 211.2 \\
\hline Luxembourg & 5.0 & 47.9 & 77.5 & - & 1.2 & 2.4 & 1.7 & 14.4 & 25.9 & 3.3 & 32.3 & 49.2 \\
\hline Netherlands & 59.8 & 178.3 & 542.1 & 4.8 & 27.1 & 166.6 & 35.0 & 77.9 & 201.8 & 20.0 & 73.3 & 173.7 \\
\hline Sweden & 17.2 & 126.1 & 126.5 & 0.7 & 23.2 & 19.7 & 13.9 & 62.0 & 64.1 & 2.6 & 40.9 & 42.8 \\
\hline Switzerland & 67.7 & 398.6 & 870.9 & 25.8 & 104.0 & 445.3 & 11.0 & 57.9 & 90.7 & 30.9 & 236.7 & 334.8 \\
\hline United Kingdom & 181.6 & 333.6 & 627.9 & 22.8 & 43.5 & 146.5 & 86.3 & 98.0 & 159.6 & 72.5 & 192.1 & 321.9 \\
\hline United States & 544.4 & 683.1 & $1,130.9$ & 200.8 & 328.4 & 553.0 & 131.7 & 120.7 & 161.5 & 211.9 & 234.0 & 416.5 \\
\hline Other & 193.5 & 698.7 & $1,083.8$ & 34.5 & 113.2 & 255.8 & 100.1 & 320.3 & 404.1 & 58.9 & 265.2 & 423.7 \\
\hline
\end{tabular}


in 1995 international interbank assets as a percentage of total foreign assets measured in capital account data were particularly large for the United States, the United Kingdom and Japan. ${ }^{26}$

Gross international interbank deposit activity, shown in Charts 6 to 8 and Table 5, is drawn from the BIS's databank, data routinely published in its Quarterly Review. This data is of two sorts, quarterly unconsolidated and semiannual consolidated statistics. ${ }^{27}$ For example, the unconsolidated interbank claims of Japanese banks on banks in Korea would include not only the international interbank liabilities of Korean banks but also the interbank liabilities of Japanese bank branches domiciled in Korea. The consolidated semiannual data removes the "intrabank" international claims, interbank depositing business between head office and foreign branches. The difference between the plotted series thus represents interbank activity between the head office and its branches in a given country.

Contrary to what was expected in the 1992 G10 study of interbank relations, after an initial period of sluggish IIBM activity in the early 1990s the volume of interbank business skyrocketed, quickly surpassing previous record levels. Total unconsolidated claims on Asian banks grew from roughly $\$ 60$ billion in 1990 to around $\$ 280$ billion in 1997. Interbank claims on Korean, Thai, Malaysian and Indonesian banks all grew to phenomenal amounts within the span of just a few years. As can be seen in Chart 7 from the large difference between the two plotted series, a good part of this lending was to branches of foreign banks in Asian developing countries. This was particularly the case in Thailand, Indonesia and Malaysia during 1996-97. The Asian crisis was obviously not only a crisis of Asian developing country banks. Also noticeable is the large amount of interbank lending to China, whose pattern of borrowing in the interbank market was similar to its Asian neighbours.

It is worth emphasising the fact that, enormous as the borrowing by domestic Asian banks in the IIBM was equally impressive was the borrowing of foreign branches resident in Asia from their head offices. A good percentage of interbank deposit-taking in Asia was by Japanese bank branches during the second half of the 1990s. With domestic demand weak, and Japan continuing to run sizeable current account surpluses, Asia provided an attractive outlet for surplus liquidity.

Japanese interbank activity during the first half of the 1990s was in sharp contrast to its behaviour during the 1980s. The 1980s can be characterised as a period of excess demand for liquidity and the 1990s as one of excess supply. During the 1980s Japan was essentially lending long-term and borrowing short-term in the international markets, in part due to domestic regulatory constraints which limited the ability of banks in Japan to raise short-term funds at home. As documented by Terrell et al. (1989), during much of the 1980s Japanese banks were confronting an excess demand for liquidity which could not be satisfied in the domestic market because of Japanese banking regulations,

\footnotetext{
26 On the determinants of international interbank deposit behaviour, see also Poulsen (1986) and Terrell et al. (1989).

27 Kertudo (1998) provides a guide to the BIS consolidated international banking statistics.
} 
specifically with respect to deposits and domestic interbank borrowing. Negotiable CDs raised in Japan were a modest percentage of total funding, even though interest rates were liberalised, due to regulatory limits on size, maturity and amounts in relation to net worth. To compensate, Japanese city banks used their foreign branches to fund domestic business. During the late 1980s the London branches of Japanese banks were extremely large issuers of dollar-denominated CDs, at one point representing $40 \%$ of the total issuance of euro-CDs in London. The international interbank market thus represented an "extremely elastic" source of funds for Japanese city banks according to Terrell et al. (1989), from which Japanese firms were provided with foreign currency financing.

Table 6

\section{Liabilities of Japanese city banks}

In 100 billions of yen

\begin{tabular}{|c|c|c|c|c|c|c|c|}
\hline & \multirow[b]{2}{*}{$\begin{array}{l}\text { Total } \\
\text { deposits }\end{array}$} & \multicolumn{6}{|c|}{ of which: } \\
\hline & & $\begin{array}{l}\text { Time depo- } \\
\text { sits with } \\
\text { liberalised } \\
\text { rates }\end{array}$ & $\begin{array}{l}\text { Foreign } \\
\text { currency } \\
\text { deposits }\end{array}$ & CDs & Call money & $\begin{array}{l}\text { Borrowed } \\
\text { from BoJ }\end{array}$ & Inter Office \\
\hline 1.12 .1980 & 854 & & 59 & 11 & 45 & 18 & 16 \\
\hline 1.12 .1981 & 940 & & 68 & 19 & 59 & 11 & 12 \\
\hline 1.12 .1982 & 990 & & 71 & 21 & 68 & 17 & 15 \\
\hline 1.12 .1983 & 1,079 & & 82 & 28 & 71 & 32 & 25 \\
\hline 1.12 .1984 & 1,148 & & 86 & 46 & 80 & 24 & 47 \\
\hline 1.12 .1985 & 1,256 & 33 & 99 & 49 & 68 & 31 & 91 \\
\hline 1.12 .1986 & 1,401 & 110 & 113 & 61 & 110 & 51 & 137 \\
\hline 1.12 .1987 & 1,749 & 289 & 220 & 64 & 124 & 52 & 116 \\
\hline 1.12 .1988 & 2,000 & 485 & 261 & 95 & 124 & 55 & 103 \\
\hline 1.12 .1989 & 2,346 & 895 & 312 & 110 & 177 & 46 & 77 \\
\hline 1.12 .1990 & 2,537 & 1,090 & 378 & 118 & 169 & 41 & 61 \\
\hline 1.12 .1991 & 2,537 & 1,001 & 291 & 110 & 253 & 52 & 53 \\
\hline 1.12 .1992 & 2,154 & 994 & 238 & 123 & 359 & 40 & 37 \\
\hline 1.12 .1993 & 2,127 & 1,088 & 196 & 153 & 364 & 33 & 52 \\
\hline 1.12 .1994 & 2,134 & 1,221 & 195 & 150 & 316 & 33 & 55 \\
\hline 1.12 .1995 & 2,228 & 1,233 & 205 & 193 & 312 & 1 & 1 \\
\hline 1.12 .1996 & 2,179 & 1,289 & 183 & 261 & 311 & 1 & 0 \\
\hline 1.12 .1997 & 2,184 & 1,243 & 194 & 307 & 310 & 37 & 38 \\
\hline 1.12 .1998 & 2,123 & 1,227 & 147 & 324 & 269 & 10 & 0 \\
\hline
\end{tabular}

This picture quickly changed during the 1990s, when the Japanese asset price bubble burst and domestic demand weakened sharply. The picture then turned to one of a large excess supply of liquidity. As shown in Table 6, the inter-office liabilities of Japanese city banks, which represent their borrowing from Japanese branches abroad, fell sharply after the late 1980s, falling from $¥ 13,700$ billion in 1986 to zero at the end of 1996. Domestic loan demand weakened and broad money growth 
Chart 9

Japan: Interest rates and bank claims on private sector

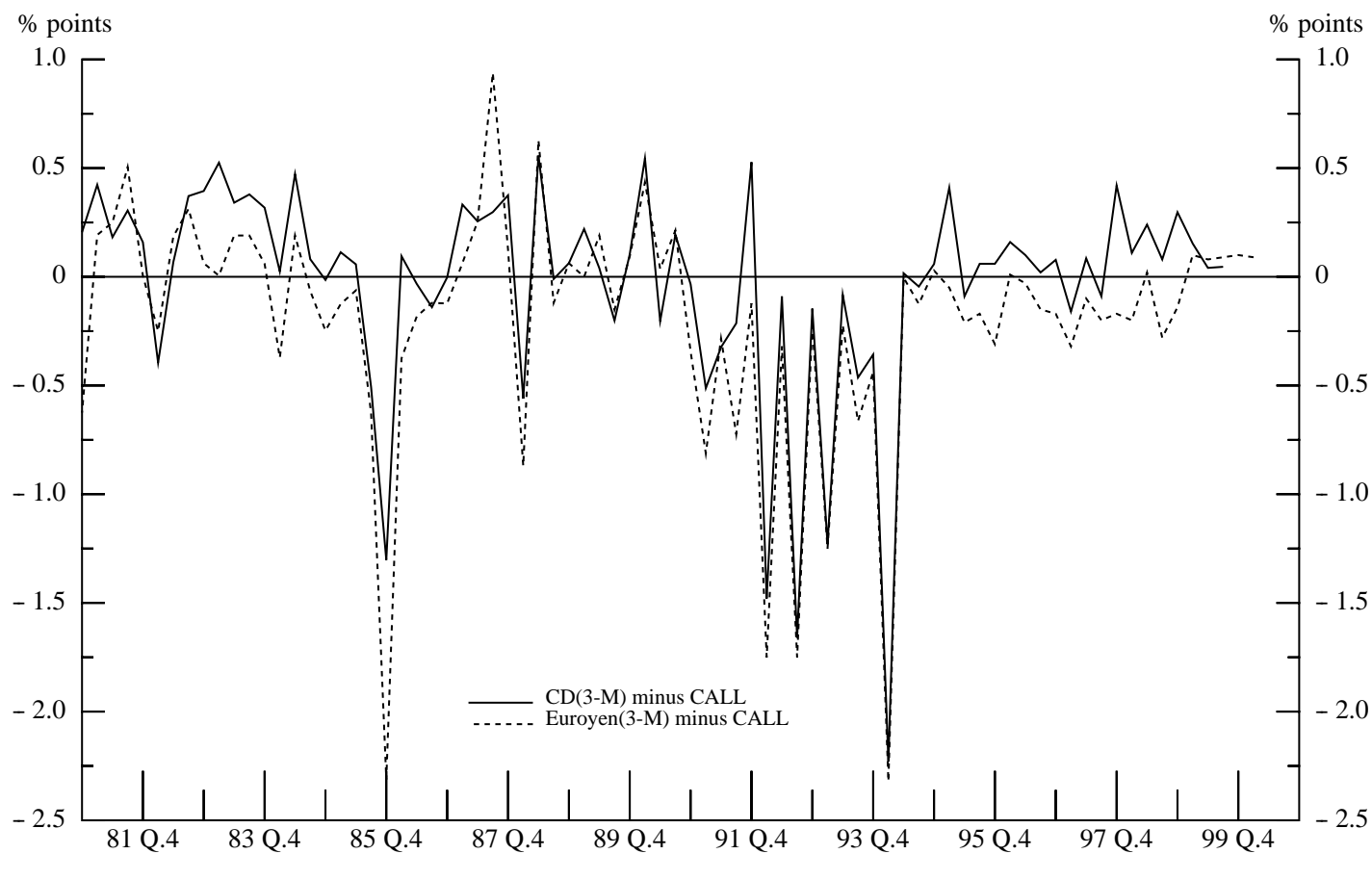

Bank claims on the domestic private sector, quarterly changes

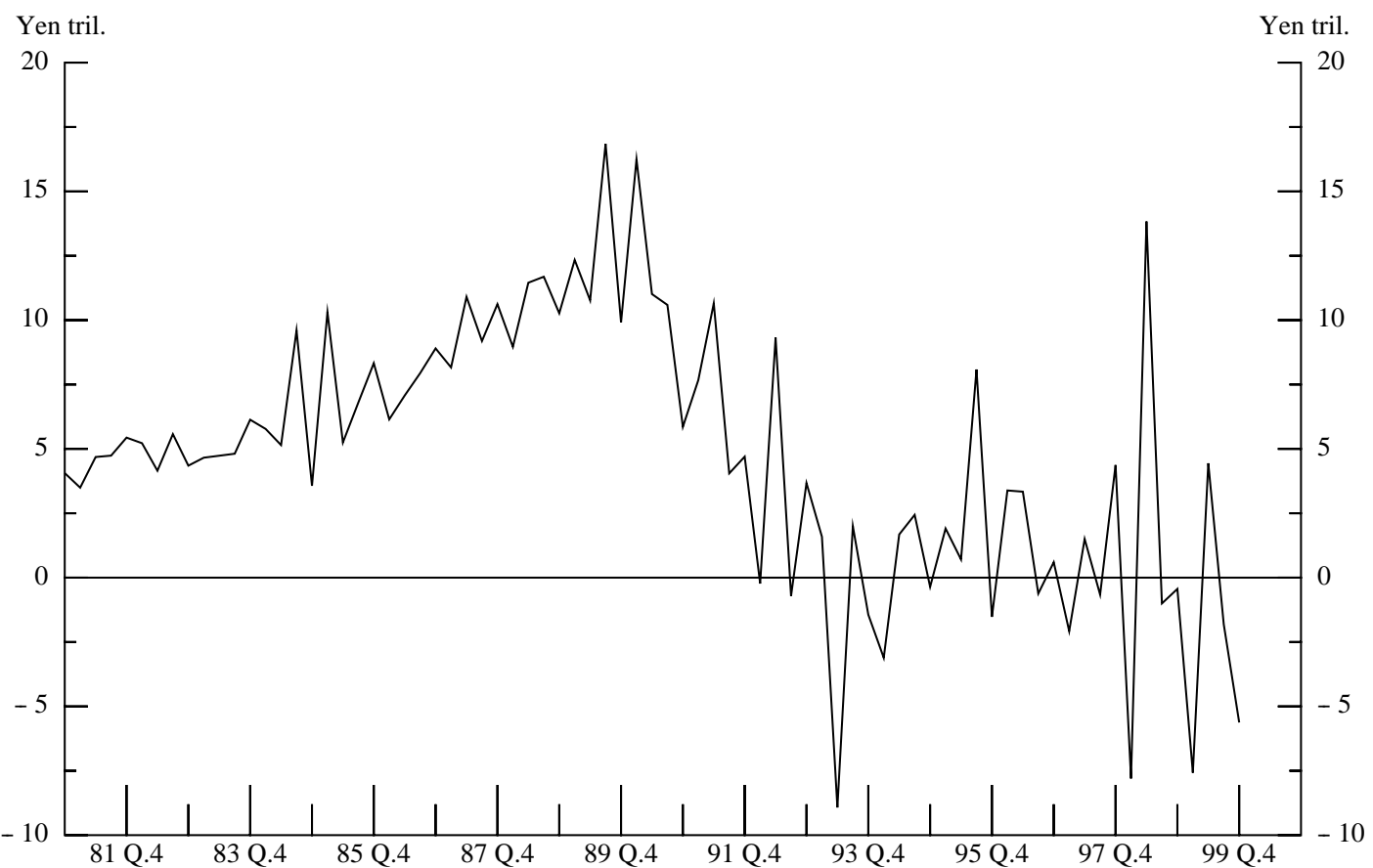

MED Research Group, HJB / 01.02.2000 at 14:59 / Function: JRB9909-BANKS IJP 
declined dramatically after 1990. The three-month CD rate fell from 7\% in 1991 to $0.3 \%$ in 1996 . Japan was facing a large excess supply of liquidity and the IIBM became the avenue into which it flowed. The weakness in demand for bank credit in Japan after 1990 can be seen in Chart 9, where we also observe a sharp fall in the spread between CD and call money rates. The onset of weak domestic loan demand in Japan corresponds closely with the growth in interbank borrowing by developing countries in Asia.

Table 7

\section{Consolidated international claims of BIS reporting banks on Asia}

In billions of US dollars

\begin{tabular}{|l|r|r|r|r|r|c|}
\hline & Dec. 1985 & Dec. 1990 & Dec. 1994 & Dec. 1996 & Dec. 1997 & Dec. 1998 \\
\hline Total & 94.3 & 135.3 & 241.2 & 367.0 & 378.8 & 297.7 \\
France & 8.8 & 14.1 & 23.7 & 38.0 & 42.9 & 33.8 \\
Germany & 3.8 & 8.2 & 20.7 & 41.7 & 48.7 & 39.8 \\
Japan & 31.4 & 60.3 & 93.3 & 118.6 & 114.7 & 85.9 \\
Netherlands & 1.6 & 2.4 & 6.8 & 12.8 & 17.3 & 18.9 \\
United Kingdom & 8.5 & 6.2 & 15.9 & 26.4 & 32.3 & 28.8 \\
United States & 22.9 & 13.2 & 19.8 & 34.2 & 29.4 & 20.2 \\
\hline Source: BIS statistics. & \multicolumn{7}{|l}{} \\
\hline
\end{tabular}

Consolidated international claims of BIS reporting banks on Latin America

In billions of US dollars

\begin{tabular}{|l|r|r|r|r|r|c|}
\hline & Dec. 1985 & Dec. 1990 & Dec. 1994 & Dec. 1996 & Dec. 1997 & Dec. 1998 \\
\hline Total & 236.5 & 184.3 & 205.7 & 242.4 & 280.3 & 288.8 \\
France & 16.8 & 16.1 & 18.3 & 19.8 & 25.0 & 22.0 \\
Germany & 15.2 & 21.0 & 26.4 & 31.3 & 36.6 & 40.9 \\
Japan & 38.5 & 31.0 & 13.6 & 15.4 & 14.7 & 14.5 \\
Netherlands & 3.6 & 6.0 & 10.2 & 14.9 & 18.4 & 22.9 \\
Spain & n.a. & 5.0 & 9.6 & 19.1 & 34.2 & 39.0 \\
United Kingdom & 20.9 & 15.0 & 15.1 & 16.0 & 21.5 & 24.0 \\
United States & 77.3 & 42.0 & 57.4 & 66.5 & 61.9 & 62.0 \\
\hline Source: BIS statistics. & \multicolumn{7}{|l}{} \\
\hline
\end{tabular}

While certainly not the whole story of the growth in external borrowing by emerging Asian economies during the 1990s, the above picture supports the argument that external factors played a significant role in the determination and sustainability of private capital flows into the five Asian countries recently in difficulties. It is also consistent with the empirical results of Fernandez-Arias (1996) which showed that the "push" of weak economic conditions in developed countries was possibly more dominant than domestic factors in explaining portfolio flows to developing countries after 1989.

The role of the IIBM in sustaining expansionary credit cycles was obvious. Just as the Japanese credit cycle and asset price bubble was aided during the 1980s by short-term funding through the 
international interbank market, so was the excessive credit expansion in developing Asian countries during the 1990s, the so-called "overborrowing syndrome" studied by McKinnon and Pill (1998). The criticism of developing Asian country governments for having misdirected credit is no doubt valid in a number of instances. But just as valid is the argument that industrial country banks which were suffering from weak loan demand at home, namely in Japan and Europe, rid themselves of excess liquidity by lending heavily in the protected international interbank deposit market. ${ }^{28}$

The importance of Japanese banks in Asia during 1990s can be seen in Table 7, which shows consolidated international claims on Asia. Note that these figures represent both consolidated bank and non-bank lending. ${ }^{29}$ While Japanese bank exposure to Asia was considerable, the aggregate exposure of European banks should also be noted.

As dramatic as the growth in international interbank claims on Asia was the sudden reversal following the 1997 Asian financial crisis, as can be seen in Chart 7. Reminiscent of a bank run, Asia experienced a dramatic loss of interbank funding in a short period of time. Gross interbank lending to banks in Thailand fell from around $\$ 85$ billion in mid-1997 to approximately \$40 billion at the end of 1998 . Large reversals also occurred in Korea, Indonesia and Malaysia. What may have gone much less noticed was the rapid increase in interbank lending to banks in China before the Asian crisis. However, China appeared to have weathered the Asian storm reasonably well, with much less of a decline in interbank funding than befell its less fortunate neighbours.

If, as Giddy (1981) suspected in the early 1980s, banks lend into the IIBM on the assumption of contingent central bank support, the market "will continue to grant credit without discrimination to large banks" (p. 184). The market will continue to "test central banks' mettle" and when that mettle is in doubt, severe credit rationing will result. That is what appeared to occur in Asia.

\subsection{Contagion in the IIBM}

The recent financial turbulence in Asia has highlighted the changing nature of modern international financial crises. Modern crises are increasingly similar to bank runs, which might be triggered by a small event which undermines investor confidence and is quickly spread to other institutions. ${ }^{30}$ The vulnerability to such crises has been amplified by the shorter maturity of international bank and non-

28 Stiglitz (1998) points to misdirection of credit in Asia by US, European and Japanese banks.

29 It is estimated that, at the time of the crisis in Thailand, 50\% of Thai banking debt came from Japanese banks. See World Bank (1999), p. 87.

30

We do not investigate here the origins of "contagion" but are biased towards thinking that in Asia it was the result of a rapid change in market sentiment relatively unrelated to any change in fundamentals or arrival of new information. Masson (1998) considers a balance of payments model to distinguish pure contagion (multiple equilibria-self-fulfilling expectations) from other crisis propagating mechanisms. See Calvo and Reinhart (1997) for evidence of contagion in capital flows and World Bank (1999) on the role of contagion in recent financial crises. 
bank lending to the public and private sectors of emerging market economies. In a recent study of financial crises in emerging markets the Institute of International Finance (1999) noted, as have others, that during the late 1980s a large part of the claims on emerging market economies were long-term bank loans. In contrast, by the end of the 1990s there was a significant adjustment towards short-term bank loans, in addition to bonds and equity. Chadha and Folkerts-Landau (1997) estimate that the share of short-tem loans in total international financing grew from around $20 \%$ in 1980 to $45 \%$ in 1996.

The short-term nature of much of the lending to emerging market countries has made them more vulnerable to reversals in confidence by the investment community. The IIF estimates that commercial bank capital flows to 29 major emerging market countries went from around $\$ 120$ billion in 1996 to -\$29 billion in 1998 (Table 1). A sizeable portion of this adjustment represented the abrupt reversal in international interbank deposits.

The sizeable growth in short-term lending to emerging market countries in general and in international interbank deposit lending in particular has increased considerably the risk of "contagion" in international financial markets. By contagion we mean here not only the interdependencies in credit flows between countries and geographical regions but also the general revision in perceptions of default risk for borrowers on whom information is scarce and whose quality is questionable. In normal periods of credit rationing in the IIBM, borrowing banks may be placed in differentiated risk pools (for example, country pools) with credit limits established for each bank and for the individual country pools. But given a large shock to any one risk pool, the questionable quality of information on borrowing banks may cause the risk pools to be merged, with even less differentiation between the credit worthiness of borrowers than before, and an increase in the default premium for the newly constituted larger group. As a result there may be less differentiation among borrowers and generalised credit rationing. ${ }^{31}$

One reason that a shock to one risk (country) group might be generalised to other groups is the uncertainty over the use of international interbank deposits by borrowing banks. The 1983 study by G10 central banks expressed serious concern about the quality of credit assessment in the IIBM. Herring (1985) referred to the "surprise and dismay" that banks with claims on Brazil experienced when they discovered that Brazilian banks were large creditors to Poland in the early 1980s. Although the 1992 central bank report on international interbank relations noted a greater concern with

31 The lack of sufficient credit screening among members of a given credit class ("tier") in the interbank market might cause problems with one bank to "infect" the perception of the quality of all members of the risk pool. Moffett (1986) builds on this idea of contagion in the interbank market. This argument is also emphasised by Saunders (1987). More recently Flannery (1996) has suggested that participants in financial markets may refuse to transact when a shock reinforces the perception of asymmetric and potentially unreliable information on counterparties. 
counterparty risk in the IIBM, no doubt a similar surprise was expressed when some large Asian borrowers in the interbank market were found to be heavy investors in Russia.

The concern with potential contagion in the international interbank market is long-standing (e.g. Dean and Giddy (1981), Herring (1985), Saunders (1987)). However, there is little direct statistical evidence of contagion being triggered by specific events, such as the failure of a large institution. Saunders (1987), for example, found no evidence of contagion in the international deposit market as a result of the Continental Illinois failure in 1984. Nor did he uncover significant signs of contagion following the Mexican-Brazilian debt crisis during the period 1982-85, using quarterly BIS data on international interbank lending. Guttentag and Herring (1985) also noted the lack of significant contagion following the 1980s Latin American debt crisis, in contrast to the fallout following the Bank Herstatt failure in 1974. It is an open question as to why contagion was not in evidence in the IIBM following the earlier crisis in Latin America, particularly given the fact, as revealed in the 1983 central bank study of the interbank market, that banks frequently dealt with counterparties on which they had only partial information with regard to management structure, balance sheets and nature of business. ${ }^{32}$

Correlations of quarterly international interbank deposit flows among developing countries may provide some evidence of the extent to which the interbank market differentiated between various deposit risk classes. Table 8 provides such correlation matrices for 11 developing countries, five Asian and six Latin American, for the period 1978 to 1998, together with three sub-periods, 1978-85, 198692 and 1993-98. Several things stand out in comparing bilateral correlations across countries and across time.

For the period as a whole, 1978-98, correlations of cross-border interbank deposit flows are much stronger among Asian countries than among countries in Latin America. For example, the KoreaThailand correlation for the entire period is 0.72 and that of Korea-Indonesia 0.68. These compare with much lower bilateral correlations in Latin America: Mexico-Chile 0.42 and Chile-Argentina 0.34. Looking across the three sub-periods we observe a very marked increase in correlations over time for the Asian countries but much less so in Latin America. This would appear to suggest that in recent years there may have been less discrimination in the IIBM among the Asian countries than in Latin America. The most notable change is that for Korea and Thailand, whose correlation went from 0.22 between 1978 and 1985 to 0.73 between 1993 and 1998. We also observe significant increases in (positive) correlations over time between Thailand and Indonesia and Korea and Indonesia.

It is interesting to observe that the three country pairs which displayed a major increase in correlations between 1993-98 and the two earlier periods (Korea-Thailand, Korea-Indonesia and ThailandIndonesia) are the same pairs for which Baig and Goldfajn (1998, p. 14) found high cross-border

32 See Bank for International Settlements (1983), p. 34. 
Table 8

Correlations of international interbank flows for Asia and Latin America

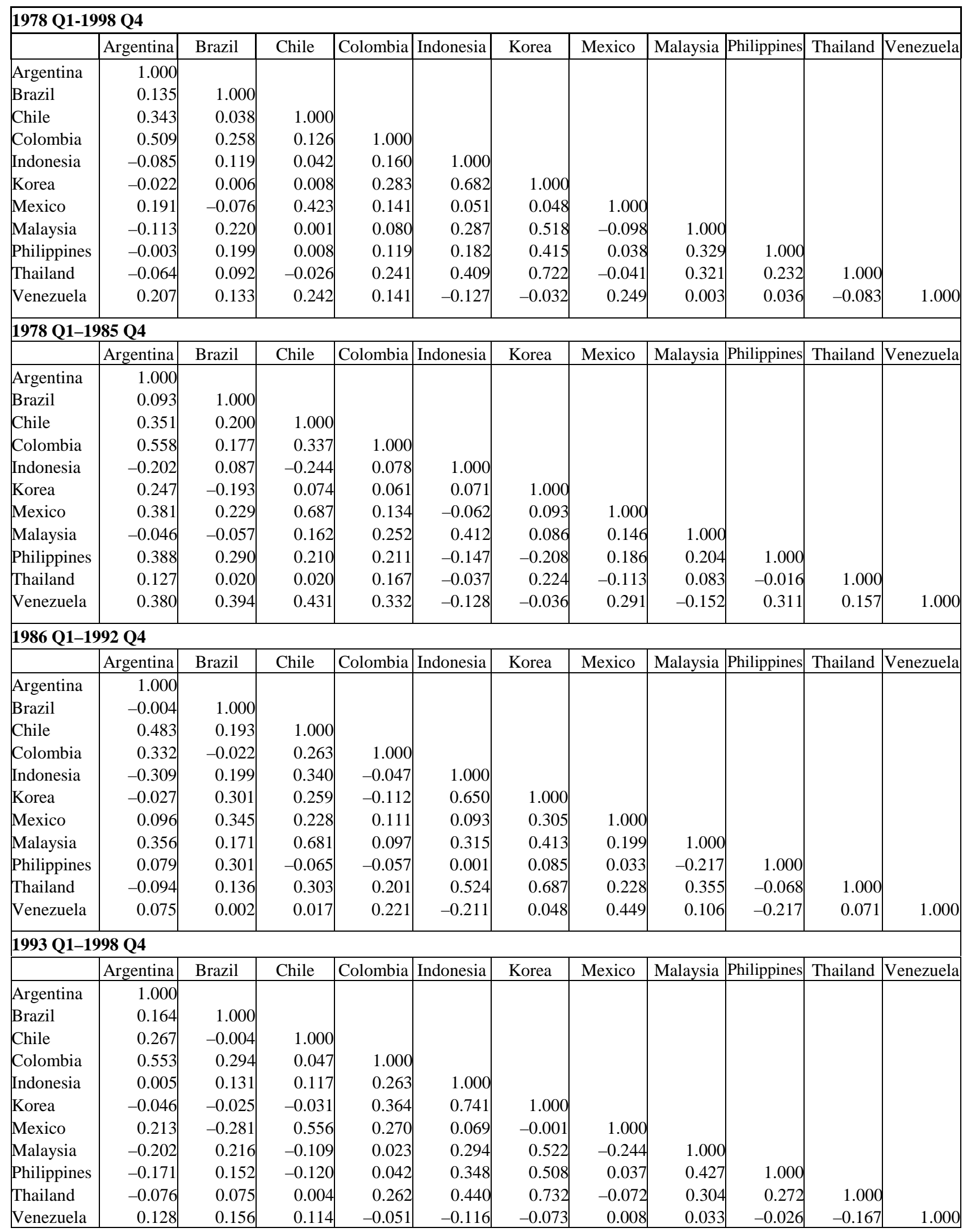


correlations in yield spreads on dollar-denominated debt for these five Asian countries (spread over like maturity US Treasury debt). And similar to our results, they found a weak correlation for the period 1993-98 for Thailand and the Philippines. They interpret their results as implying that higher risk premiums were being levied on Asian dollar-denominated debt to compensate for the increased financial fragility. Our results can be interpreted as suggesting that during the 1993-98 interval the IIBM appeared to differentiate less among these five Asian participants in the market.

Contemporaneous correlations between Asian and Latin America pairs are seen to be relatively weak. Among the six Latin American countries we observe a decline in (positive) correlations between 1978-85 and 1986-92 for Mexico-Argentina, Mexico-Chile and Venezuela-Brazil, suggesting greater differentiation among Latin American borrowers. For the more recent period 1993-98 several of the correlations rise (e.g. Mexico-Chile, Columbia-Argentina) but remain smaller than those seen for the Asian group. The only significant reversal in sign is that for Mexico and Brazil, which turned negative for the final period.

These results using international interbank deposit flows lend some support to the argument, consistent with credit rationing (Saunders (1987)), that lenders in the IIBM may have had greater difficulty distinguishing among international borrowing classes during the Asian crises, resulting in a significant increase in positive correlations of interbank flows. This appears to be consistent with evidence of contagion available in spreads of Asian sovereign borrowing during 1997-98. Evidence of international interbank "contagion" appears on the whole much weaker in Latin America.

Further evidence of possible contagion in the IIBM can be obtained by estimating Granger "causality tests". While one must be cautious not to over-interpret such tests, they can be useful in detecting the influence on a variable conditioned on its past behaviour. ${ }^{33}$

The Granger tests were run for three sets of pairs, those within Asia, those within Latin America, and among the combination of 11 Asian and Latin American countries. These tests confirm what was earlier seen in the matrix of contemporaneous correlations. There is evidence of contagion (temporal directional influence) in Asia, using data over the entire 1978-98 period, but little significant sign of it in Latin America. Between the two regional groupings, the evidence seems to point to "causality" running from Asia to Latin America rather than the reverse.

In Asia, Table 9 reveals statistically significant directional influence from Thailand to Korea and Indonesia. Korean flows also may have triggered a reaction in Indonesia. The other tests seem to imply strong "bilateral causality". These results contrast sharply with those for Latin American

33 These tests can be influenced by specification of lag length, although for the tests reported in Tables 9 to 12 alternative lag length specifications made little difference to the results. 
countries. Among the tests reported in Table 10, there is little evidence of a causal relation, save one going from Brazil to Chile.

The bilateral causality tests between the five Asian and six Latin American countries point to significant directional influence. In most of the cases reported in Table 11 the "direction of causality" appears to be from Asia to Latin America. This is most clearly seen in the influence of Korean interbank flows on Brazilian interbank deposit-taking. We also observe a significant influence of Korea, the Philippines and Malaysia on Argentina. Also noted, as might be expected, is evidence of strong "bilateral causality" between Brazil and Thailand.

Table 9

\section{Granger tests of causality of Asian international interbank deposit flows: quarterly data 1978Q1-1998Q4; four lags}

Data adjusted for changes in exchange rates

\begin{tabular}{|l|l|l|c|c|}
\hline & Null hypothesis & & F-statistic & P-value \\
\hline Thailand & (does not Granger cause) & Korea & 14.84 & 0.00 \\
Korea & (does not Granger cause) & Thailand & 0.72 & 0.58 \\
Indonesia & (does not Granger cause) & Indonesia & 9.21 & 0.00 \\
Thailand & (does not Granger cause) & Thailand & 0.70 & 0.59 \\
Malaysia & (does not Granger cause) & Malaysia & 6.73 & 0.00 \\
Thailand & (does not Granger cause) & Thailand & 5.09 & 0.00 \\
Philippines & (does not Granger cause) & Philippines & 6.73 & 0.00 \\
Korea & (does not Granger cause) & Thailand & 5.09 & 0.00 \\
Indonesia & (does not Granger cause) & Indonesia & 8.92 & 0.00 \\
Korea & (does not Granger cause) & Korea & 0.76 & 0.56 \\
Malaysia & (does not Granger cause) & Malaysia & 5.72 & 0.00 \\
Korea & (does not Granger cause) & Korea & 4.25 & 0.00 \\
Philippines & (does not Granger cause) & Philippines & 3.64 & 0.01 \\
\hline
\end{tabular}

Even given the necessary caution in interpreting statistical results such as those provided here, they appear to overturn the results of earlier studies which failed to uncover evidence of contagion in the international interbank market. Further evidence is provided when the sample is split into one including the 1982 crisis in Latin America (1978-87 not reported here) and the second the Asian crisis (1988-98). These Granger tests reveal clear evidence of contagion in the second period and, similar to 
Saunders' (1987) results, little support for contagion in the interbank market from 1978-87. The tests for the latter period found, somewhat surprisingly, Argentina influencing Mexican interbank activity but not the reverse, and little else of significance. Tests for the 1988-98 period, shown in Table 12, reveal considerable directional influence. Indeed, the first six pairs of tests in Table 12 display quite strong evidence of the interbank activity in Asia influencing interbank flows in Latin America. ${ }^{34}$ Korea is found to have had a strong statistical influence on interbank flows to Brazil. And in Asia we see an impressive influence of Thai interbank activity on flows to Korea, as well as significant results for other intra-Asia activity.

Table 10

\section{Granger tests of causality of Latin American international interbank deposit flows: quarterly} data 1978-1994; four lags

Data adjusted for changes in exchange rates

\begin{tabular}{|l|l|l|c|c|}
\hline & Null hypothesis & & F-statistic & P-value \\
\hline Brazil & (does not Granger cause) & Argentina & 1.56 & 0.19 \\
Argentina & (does not Granger cause) & Brazil & 1.75 & 0.15 \\
Argentina & (does not Granger cause) & Argentina & 1.79 & 0.14 \\
Mexico & (does not Granger cause) & Chile & 1.46 & 0.22 \\
Argentina & (does not Granger cause) & Argentina & 0.42 & 0.79 \\
Chile & (does not Granger cause) & Mexico & 0.03 & 0.99 \\
Brazil & (does not Granger cause) & Brazil & 1.04 & 0.40 \\
Mexico & (does not Granger cause) & Chile & 4.66 & 0.00 \\
Brazil & (does not Granger cause) & Brazil & 0.66 & 0.62 \\
Mexico & (does not Granger cause) & Mexico & 1.48 & 0.22 \\
Chile & (does not Granger cause) & Chile & 0.35 & 0.84 \\
& (does not Granger cause) & Mexico & 0.23 & 0.91 \\
\hline
\end{tabular}

These findings support the argument that greater contagion in the international interbank market has emerged in recent years in comparison with the period following the 1982 Latin American crisis. The concern earlier raised by Herring (1985) and others that "in times of stress, the interbank market may become a primary source of contagion" appears to have been borne out by recent events.

34 The shorter lags were used to save on degrees of freedom. 
Table 11

Granger tests of causality of Latin American and Asian international interbank deposit flows: quarterly data 1978Q1-1998Q4; four lags

Data adjusted for changes in exchange rates

\begin{tabular}{|c|c|c|c|c|}
\hline & Null hypothesis & & F-statistic & P-value \\
\hline Argentina & (does not Granger cause) & Korea & 1.86 & 0.13 \\
\hline Korea & (does not Granger cause) & Argentina & 3.30 & 0.02 \\
\hline Argentina & (does not Granger cause) & Malaysia & 1.09 & 0.37 \\
\hline Malaysia & (does not Granger cause) & Argentina & 4.58 & 0.00 \\
\hline Argentina & (does not Granger cause) & Philippines & 0.64 & 0.63 \\
\hline Philippines & (does not Granger cause) & Argentina & 4.26 & 0.00 \\
\hline Argentina & (does not Granger cause) & Thailand & 3.12 & 0.02 \\
\hline Thailand & (does not Granger cause) & Argentina & 2.15 & 0.08 \\
\hline Brazil & (does not Granger cause) & Korea & 1.27 & 0.29 \\
\hline Korea & (does not Granger cause) & Brazil & 9.59 & 0.00 \\
\hline Brazil & (does not Granger cause) & Thailand & 5.69 & 0.00 \\
\hline Thailand & (does not Granger cause) & Brazil & 8.18 & 0.00 \\
\hline Mexico & (does not Granger cause) & Korea & 1.20 & 0.32 \\
\hline Korea & (does not Granger cause) & Mexico & 0.36 & 0.83 \\
\hline Mexico & (does not Granger cause) & Thailand & 1.31 & 0.28 \\
\hline Thailand & (does not Granger cause) & Mexico & 0.68 & 0.61 \\
\hline
\end{tabular}


Table 12

\section{Granger tests of causality of Asia and Latin American international interbank deposit flows: quarterly data 1988Q1-1998Q4; two lags}

Data adjusted for changes in exchange rates

\begin{tabular}{|c|c|c|c|c|}
\hline & Null hypothesis & & F-statistic & P-value \\
\hline Malaysia & (does not Granger cause) & Argentina & 3.70 & 0.03 \\
\hline Argentina & (does not Granger cause) & Malaysia & 0.12 & 0.88 \\
\hline Philippines & (does not Granger cause) & Argentina & 4.81 & 0.01 \\
\hline Argentina & (does not Granger cause) & Philippines & 0.25 & 0.78 \\
\hline Korea & (does not Granger cause) & Brazil & 8.24 & 0.00 \\
\hline Brazil & (does not Granger cause) & Korea & 0.51 & 0.60 \\
\hline Indonesia & (does not Granger cause) & Chile & 3.72 & 0.03 \\
\hline Chile & (does not Granger cause) & Indonesia & 1.30 & 0.28 \\
\hline Malaysia & (does not Granger cause) & Chile & 4.44 & 0.02 \\
\hline Chile & (does not Granger cause) & Malaysia & 0.41 & 0.67 \\
\hline Korea & (does not Granger cause) & Columbia & 3.42 & 0.04 \\
\hline Columbia & (does not Granger cause) & Korea & 0.38 & 0.69 \\
\hline Korea & (does not Granger cause) & Indonesia & 6.94 & 0.00 \\
\hline Indonesia & (does not Granger cause) & Korea & 0.97 & 0.38 \\
\hline Malaysia & (does not Granger cause) & Indonesia & 3.31 & 0.04 \\
\hline Indonesia & (does not Granger cause) & Malaysia & 2.19 & 0.13 \\
\hline Thailand & (does not Granger cause) & Indonesia & 5.53 & 0.01 \\
\hline Indonesia & (does not Granger cause) & Thailand & 0.10 & 0.90 \\
\hline Malaysia & (does not Granger cause) & Korea & 3.90 & 0.03 \\
\hline Korea & (does not Granger cause) & Malaysia & 5.00 & 0.01 \\
\hline Thailand & (does not Granger cause) & Korea & 9.26 & 0.00 \\
\hline Korea & (does not Granger cause) & Thailand & 0.07 & 0.93 \\
\hline Philippines & (does not Granger cause) & Malaysia & 4.28 & 0.02 \\
\hline Malaysia & (does not Granger cause) & Philippines & 0.42 & 0.66 \\
\hline
\end{tabular}




\section{The changing nature of international financial flows and crises}

\subsection{Push and pull of capital flow crises}

Looking back over the past two decades it is easy to be overwhelmed by the growth and volatility of international portfolio and interbank flows to developing countries. The source, direction, type, maturity and terms of this lending are of particular interest. Tables 13 to 15 summarise the change in the composition of the external debt of developing countries. What we observed between 1988 and 1997, as a percentage of total borrowing by developing countries, was less borrowing by the public sector and more by the private sector (Table 13). Increasingly more of the private sector borrowing was by banks. These adjustments open up the question of the interplay of economic and financial conditions in lending and borrowing countries in contributing to recent crises.

Table 13

\section{Composition of external debt for major emerging market economies}

In billions of dollars and percentages

\begin{tabular}{|c|c|c|}
\hline & 1988 & 1997 \\
\hline Total $^{1}$ & 944.7 & $1,882.7$ \\
\hline By creditor $(\%):^{1}$ & 100.0 & 100.0 \\
\hline International financial institutions & 14.7 & 12.6 \\
\hline Official bilateral creditors & 27.5 & 21.2 \\
\hline Commercial banks & 45.3 & 34.3 \\
\hline Other private creditors & 12.5 & 31.9 \\
\hline By borrower $(\%):^{2}$ & 100.0 & 100.0 \\
\hline Public sector & 75.5 & 49.5 \\
\hline Deposit money banks & 11.2 & 23.7 \\
\hline Other private sector & 13.2 & 26.8 \\
\hline
\end{tabular}

Net long-term commercial bank flows (original maturity greater than one year) to developing countries were relatively moderate during the first half of the 1990s, while net bond and portfolio equity flows grew strongly and steadily through this period, as seen in Table 14. Following the Mexican crisis in late 1994 net commercial bank lending jumped sharply while net bond financing fell back. There appeared to be some significant substitution of bank for bond financing after 1994. The total net longterm resource flow from commercial banks was \$161.3 billion between 1995 and 1998 compared with $\$ 152.9$ billion net long-term bond financing. This contrasts with net long-term flows of $\$ 41.5$ billion and $\$ 96.8$ billion, respectively, for the 1990-94 interval. During the 1990s the maturity of syndicated lending to Asia declined, as can be seen in Chart 10. 
Chart 10

Asia: all debtors, syndicated loans

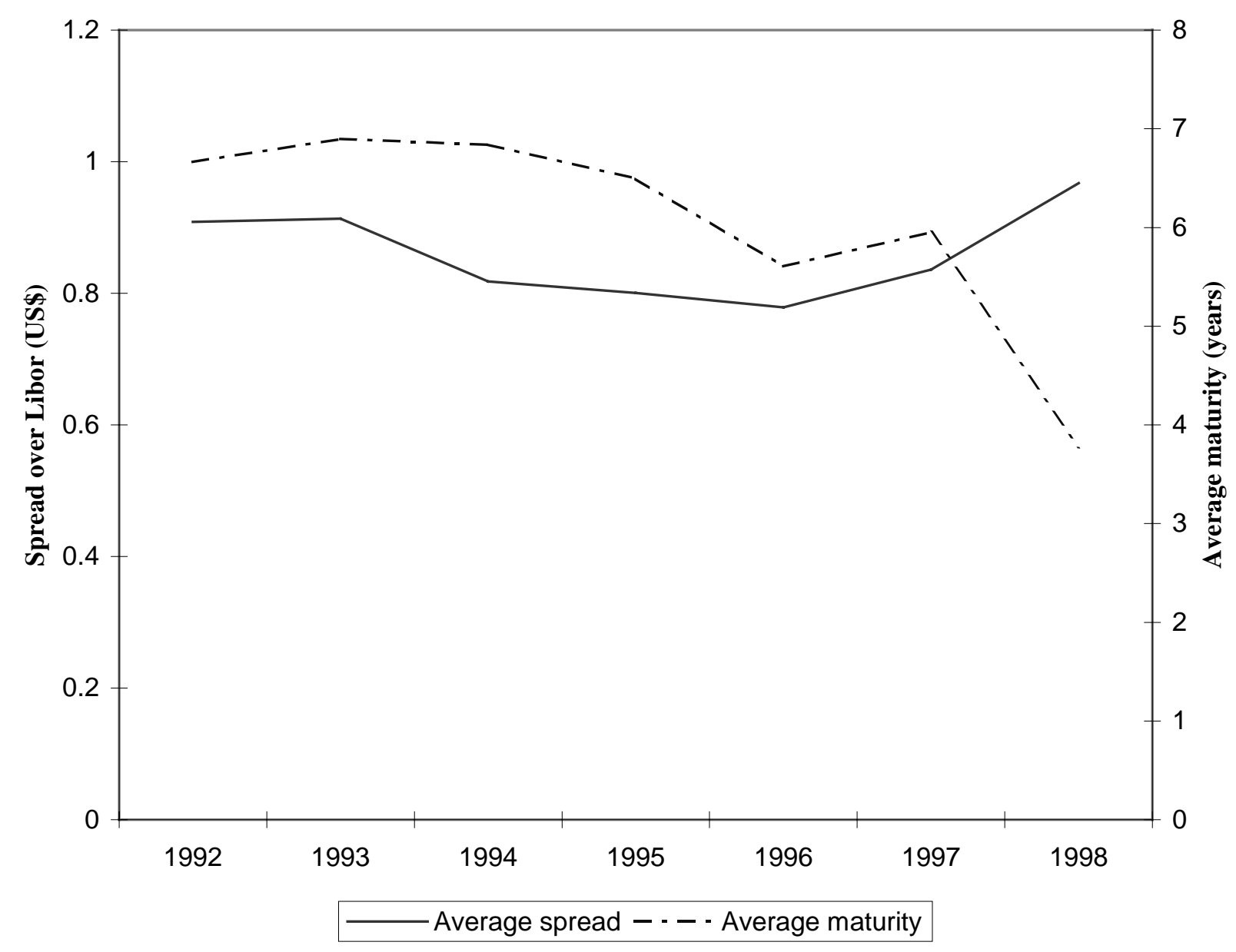

Source: Capital Data. 
Chart 11

Asia: syndicated loans to banks

Average maturity and spread over Libor

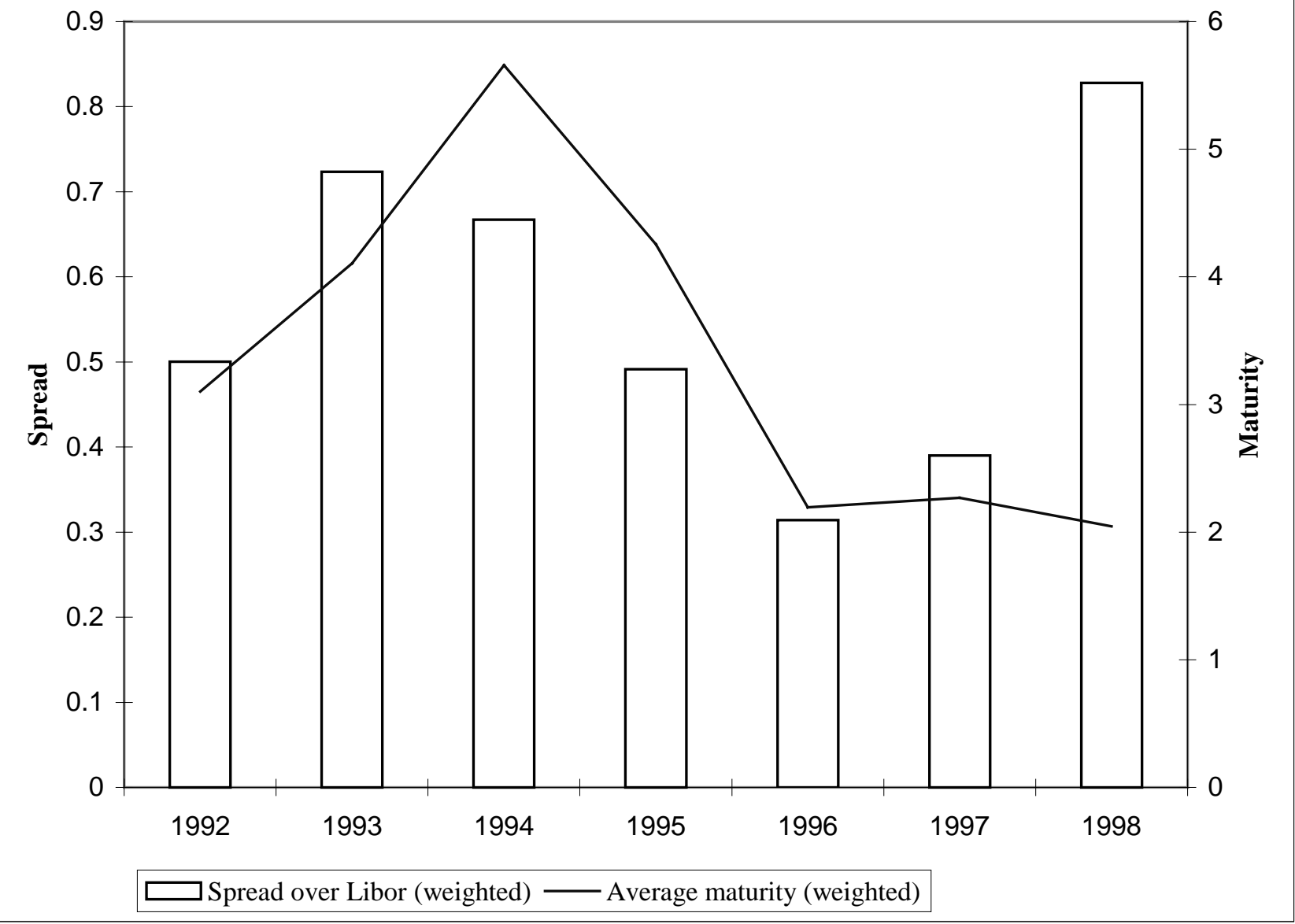

Source: Capital Data. 
Table 14

Net long-term resource flows to developing countries, 1990-98

In billions of US dollars

\begin{tabular}{|l|r|r|r|r|r|r|r|r|r|}
\hline & 1990 & 1991 & 1992 & 1993 & 1994 & 1995 & 1996 & 1997 & $199 *^{*}$ \\
\hline Net long-term resource flows & 100.8 & 123.1 & 152.3 & 222.2 & 223.5 & 254.9 & 308.1 & 338.1 & 275.0 \\
Official flows & 56.9 & 62.6 & 54.0 & 53.3 & 45.5 & 53.4 & 32.2 & 39.1 & 47.9 \\
Private flows & 43.9 & 60.5 & 98.3 & 167.0 & 178.1 & 201.5 & 275.9 & 299.0 & 227.1 \\
From international capital & & & & & & & & & \\
markets & 19.4 & 26.2 & 52.2 & 100.0 & 89.6 & 96.1 & 149.5 & 135.5 & 72.1 \\
Private debt flows & 15.7 & 18.6 & 38.1 & 49.9 & 54.4 & 60.0 & 100.3 & 105.3 & 58.0 \\
Commercial banks & 3.2 & 4.8 & 16.3 & 3.3 & 13.9 & 32.4 & 43.7 & 60.1 & 25.1 \\
Bonds & 1.2 & 10.8 & 11.1 & 37.0 & 36.7 & 26.6 & 53.5 & 42.6 & 30.2 \\
Others & 11.4 & 3.0 & 10.7 & 8.6 & 3.7 & 1.0 & 3.0 & 2.6 & 2.7 \\
Portfolio equity flows & 3.7 & 7.6 & 14.1 & 51.0 & 35.2 & 36.1 & 49.2 & 30.2 & 14.1 \\
Foreign direct investment & 24.5 & 34.4 & 46.1 & 67.0 & 88.5 & 105.4 & 126.4 & 163.4 & 155.0 \\
\hline
\end{tabular}

Note: Net long-term resource flows are defined as net liability transactions of original maturity greater than one year. Although the Republic of Korea is a high-income country, it is included in the developing country aggregate since it is a borrower from the World Bank.

* Preliminary.

Source: World Bank Global Development Finance, 1999.

Table 15

Short-term debt flows of developing countries, 1990-98

In billions of US dollars

\begin{tabular}{|l|r|r|r|r|r|}
\hline & 1990 & 1995 & 1996 & 1997 & 1998 \\
\hline All developing countries & 19.5 & 61.1 & 31.2 & 21.1 & 4.9 \\
East Asia and Pacific & 11.9 & 43.1 & 19.1 & 2.7 & -6.1 \\
Latin America and the Caribbean & 9.1 & 5.6 & 0.8 & 10.3 & 0.9 \\
Middle East and North Africa & 1.7 & -0.6 & 0.0 & -1.5 & 0.4 \\
South Asia & 1.6 & 2.1 & 1.2 & -2.1 & 1.4 \\
Sub-Saharan Africa & 2.3 & 2.8 & 2.4 & 3.3 & 1.5 \\
Europe and Central Asia & -7.0 & 8.2 & 7.7 & 8.4 & 6.9 \\
\hline
\end{tabular}

Note: Short-term debt is defined as debt with original maturity of one year or less.

Sources: World Bank; BIS.

The size and volatility of short-term (original maturity of one year or less) debt flows to developing countries during the 1990s, and the part played by East Asia and the Pacific, can be seen in Table 15. Short-term debt flows to East Asia and the Pacific went from $\$ 43$ billion in 1995 to $-\$ 6.1$ billion in 1998, a good portion of which were interbank flows. Giannini (1999), Bisignano (1999) and others have pointed in particular to the enormous growth in international interbank flows to Thailand, Malaysia, Indonesia, Korea and the Philippines in 1995 and 1996, and their subsequent tumble. What 
begs explanation is the large growth in commercial bank lending to Asian countries from 1995 to 1997, much of which was interbank lending. The World Bank (1999) has argued that long-term bank loans appear to be much more resilient than bond financing in periods of financial stress, possibly due to the desire to sustain long-term relations and to maintain information on borrowers, while at the same time banks may withdraw short-term funding. This argument has also been put forward by Chadka and Folkerts-Landau (1997). They noted that in the wake of the Mexican crisis in 1995 longterm bank lending surpassed the new flow of bond finance to emerging market countries.

The story of commercial banks being a more stable source of funding during crises, substituting for capital market issuance, does not ring completely true. In 1998 both long-term commercial bank and bond flows to emerging market countries fell off sharply. In addition, short-term debt flows, which include interbank lending, plummeted. Instead, apart from foreign direct investment, greater financial integration has meant greater volatility in financial flows and contagion for countries with similar structural characteristics. ${ }^{35}$

In attempting to understand the recent crises in Asia three questions of "substitutability" arise: the substitutability of bank and capital market financing; the substitutability by developed countries of lending to alternative developing countries; and the substitutability of bank lending to developing countries between syndicated commercial lending and international interbank lending. From recent data it appears unclear whether there is any stable substitution relation between bond financing and bank lending to developing countries. Debt commitment data (World Bank (1999)) indicates that even though bank commitments to the private sector of developing countries rose at a healthy pace in 1997 while bond commitments rose only modestly, both fell sharply in 1998 .

During the past decade Japan had consistently lent much more to Asia than to Latin American countries. Its share of total international borrowing by the major emerging Asian countries was between 30 and 40\% during the 1990s. Europe's share rose to around 40\% in 1997 while the US share to Asia has remained at or below 10\%. It is to be noted that BIS data indicates that Europe's share of international bank lending to both Asia and Latin America rose significantly during the decade, capturing $40 \%$ and $50 \%$, respectively, in $1997 .^{36}$

We have little evidence but some suspicion that banks in the industrial countries at times may substitute interbank lending for direct syndicated commercial lending to developing countries. Several reasons may be given for this conjecture. Interbank lending is obviously of shorter maturity and carries in many cases an implicit guarantee; moreover, since 1988 short-term lending has had a lower capital requirement than commercial lending. Although yields on interbank lending may be much lower than

35 Agenor and Aizenmann (1998) look at how imperfections in domestic capital markets can increase instability in the real economy when domestic banks borrow on world capital markets.

36 See also Ito (1999), Table 7. 
those on direct commercial lending, a lower risk weight would to some degree compensate for the yield differential. The lower risk weight on short-term interbank lending to non-OECD countries may arguably have played some role in increasing short-term interbank lending to these countries. There is evidence to suggest that non-OECD countries had a higher level of short-term interbank borrowing than similarly credit rated banks in OECD countries. ${ }^{37}$ Although the influence of risk weights on bank lending is a difficult issue to resolve, the recent study by banking supervisory officials (Bonte et al. (1999), p. 14) stressed that "a significant element of moral hazard may have existed" in G10 bank lending to Asian countries as a result of the assumption of implicit government guarantees.

Following the Mexican crises in late 1994-early 1995 there were a number of factors external to the emerging market countries, especially in Asia, which could have encouraged commercial bank flows to them. The low interest rates in the industrial countries, the excess short-term liquidity in both Japan and Europe and weak domestic loan demand all contributed to a "push" of funds into emerging market countries. An analysis of the causes of the Asian crises would appear to be shortsighted if it focused only, or even primarily, on the weak structure of Asian financial systems, poor corporate governance and close government-business ties. ${ }^{38}$ The abundant liquidity available in industrial countries and their implicit government guarantee related incentives to lend into the IIBM are equally relevant in understanding the origins of recent international financial crises. ${ }^{39}$

\subsection{Moral hazard, implicit and explicit guarantees and the restoration of confidence}

The recent Asian crisis was in good part a crisis in the interbank market which arguably could only be stabilised by providing official support and assurances to this market. Much of the bank lending to Asian countries between 1994 and 1996 was interbank financing, rather than direct lending to the nonbank sector (Table 16). When the crisis hit in 1997 the biggest change in the external position of BIS reporting banks to Asian countries was in interbank positions.

To illustrate this point consider the experiences of Korea and Thailand. Between the end of 1996 and the end of 1998 bank claims of the BIS reporting countries on Korea (adjusted for exchange rate changes) fell by a total of $\$ 35.4$ billion. Of this total only $\$ 6$ billion represented a decline in lending to the non-bank sector. For Thailand the figures are even more striking. External banks' claims on Thailand fell by $\$ 41.5$ billion, of which only $\$ 3.4$ billion were claims on the non-bank sector. Even the

37 Bonte et al. (1999) examine the role of the interbank risk weights (20\% for less than one year interbank lending for OECD and non-OECD countries and $100 \%$ for longer-term interbank lending to non-OECD countries) on the lending to Asian countries. See Chapter 4. The statistical evidence is generally inconclusive.

38 Fernandez-Arias (1996) found that for most middle-income developing countries the surge in capital inflows would not have occurred between 1989 and 1993 had it not been for the large decline in international interest rates.

39 Kim and Rhee (1998) argue that international money managers and investment banks went on a "lending binge" to Asian countries between 1993 and 1996 while credit rating agencies engaged in "competitive upgradings" of East Asian countries "reflecting rating companies' desire to expand their business scope". 
strong assumption of implicit government guarantees of international interbank lending was not sufficient to prevent a mass exodus of interbank funding. This illustrates the extreme vulnerability of markets with serious adverse selection problems.

Similar behaviour can be observed in lending by BIS reporting banks to Latin America. During 1994 interbank lending to Brazil fell by $\$ 11$ billion, while lending to the non-bank sector actually increased (Table 17). And in Mexico in 1995 the decline in international bank lending was in the interbank market, not in lending to the non-bank sector.

The magnitude of the flight of interbank lending from Asia was unparalleled in the history of international financial crises, reminiscent of a "bank run". The decline in net external finance to the five stricken Asian countries between 1996 and 1997 represented roughly 5\% of the GDP of these countries. ${ }^{40}$ Given the previous confidence investors had in Asia and even allowing for knowledge of the large external indebtedness of Asian countries, the magnitude of the "run" is difficult to understand. Was the "news" on individual countries so remarkable or were the similarities with other countries in crisis so significant as to merit such a massive withdrawal of interbank funding? Alone, fundamentals do not appear sufficient to explain the flight of liquidity from Asia. What needs to be investigated is the risk aversion of foreign bank lending to Asian banks in the interbank market and whether the rapid and enormous withdrawal of interbank funding from Asia represented an "information-based run" or a "pure panic run". 41

A central element in the restoration of confidence in Asia was the assurance given creditor banks. In some cases a system of implicit guarantees which contributed to the foreign banking inflow was converted into explicit guarantees in order to restore credibility during the crisis. At the start of 1998 the Korean government acted quickly with guarantees of its banks' liabilities, obtaining agreement with creditor banks to roll over maturing liabilities. In March 1998 the government arranged for the conversion of $\$ 24$ billion of short-term bank debt into debt with one to three-year maturities. ${ }^{42}$ Moreover, of the $\$ 24$ billion of the now longer-maturity bank debt, all but $\$ 4$ billion was guaranteed by the Korean government.

The rapid intervention of the Korean government in restructuring and assuring the repayment of bank debt went a long way to preventing an even larger economic crisis. The return of confidence in Korea was equally rapid. Unlike the funding difficulties of Latin American countries following the Mexican

See World Bank (1999), Chapter 1.

41 Jacklin and Bhattacharya (1988) model bank runs and distinguish between information-based runs and pure panic runs. They show the importance of market knowledge of the future liquidity of the bank and the important role of the risk aversion of depositors. Bank runs may not be troublesome when depositors are not terribly risk averse and have some assurance about the future liquidity of the bank.

42 The restructured bank debt carried interest rates of 2.25-2.75\% above six-month Libor. 
crisis in 1982, in April 1998 Korea re-entered the world capital markets and issued its first sovereign bonds with five and 10-year maturities.

Similar to Korea, Indonesian banks converted international interbank liabilities into loans with maturities of one to four years. It is unclear if any explicit government guarantees were involved. Banking debt in Thailand, a large portion of which is held by Japanese banks, was also converted into longer maturities. Again the role of government guarantees is unclear. But as we have recently seen in Japan and earlier saw in the industrial counties, for example in Sweden, direct government intervention with explicit liability guarantees is often essential to restore confidence to a severely weakened financial system.

What is potentially worrisome is the impact the resolution of the international interbank crisis in Asia will have on the perception of the government guarantees which underpin the market. With foreign banks receiving large explicit official guarantees on their lending, \$20 billion worth to Korean banks, it seems unlikely that over the long run the moral hazard problem will be reduced. Notwithstanding the need for the Korean government to quickly restore international investor confidence and the desire to avoid a large contraction in credit availability, the example can hardly be expected to restore confidence in the unassisted private allocation of international liquidity.

While there is good cause for concern that government and international intervention to support banks in Asia may have increased the moral hazard problem in the IIBM, the additional moral hazard risk should not be exaggerated, as it was already very high. There is little evidence, for example, that the official international rescue provided to Mexico during the 1995 peso crisis was a major cause of the growth in international lending to Asia after the crisis. ${ }^{43}$ The point made by the Institute of International Finance (1999) that the fall in yield spreads over US Treasuries was just as big for junk bonds as it was for emerging market countries' eurobonds is well taken. In addition to moral hazard, equal attention should be given to the "push" factors, such as the very high degree of international liquidity, a large part of which was funnelled through the interbank market, and the official attitude towards the IIBM.

43

See Zhang (1999) on this issue. 


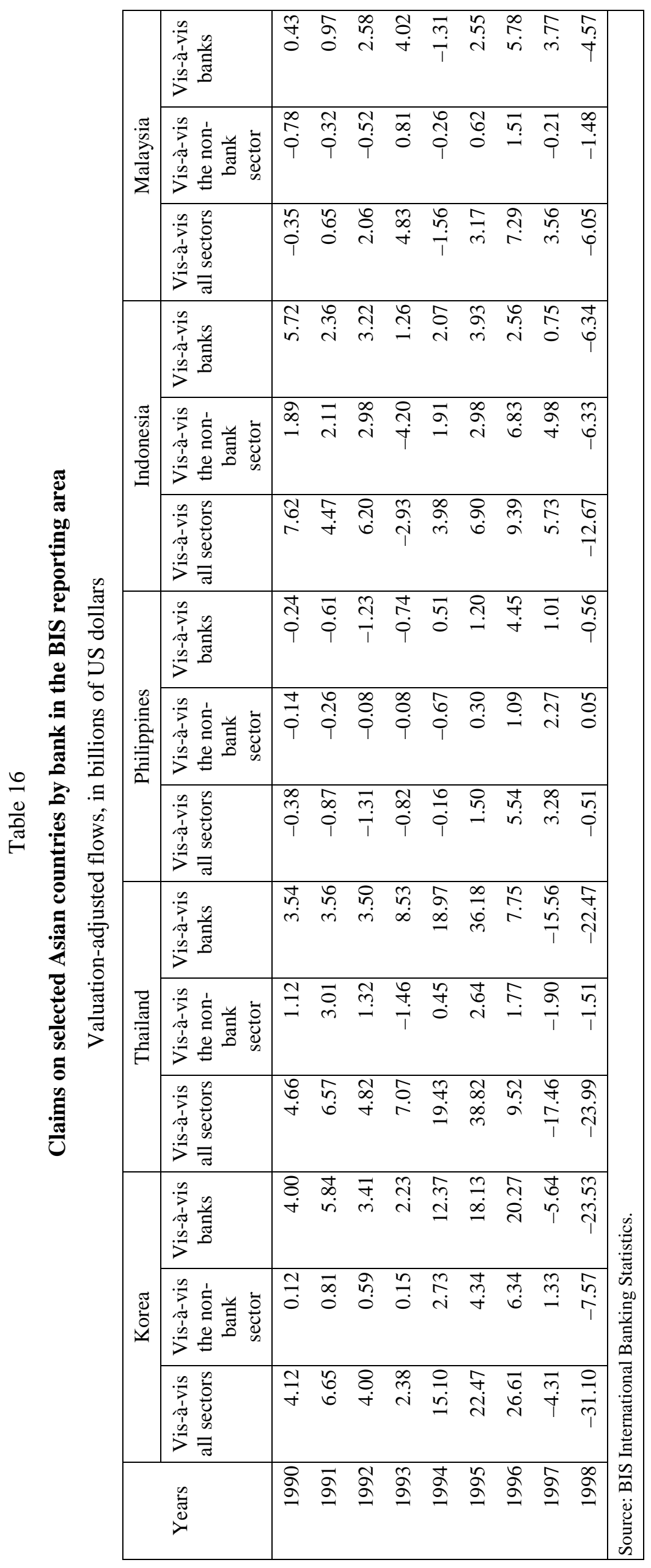




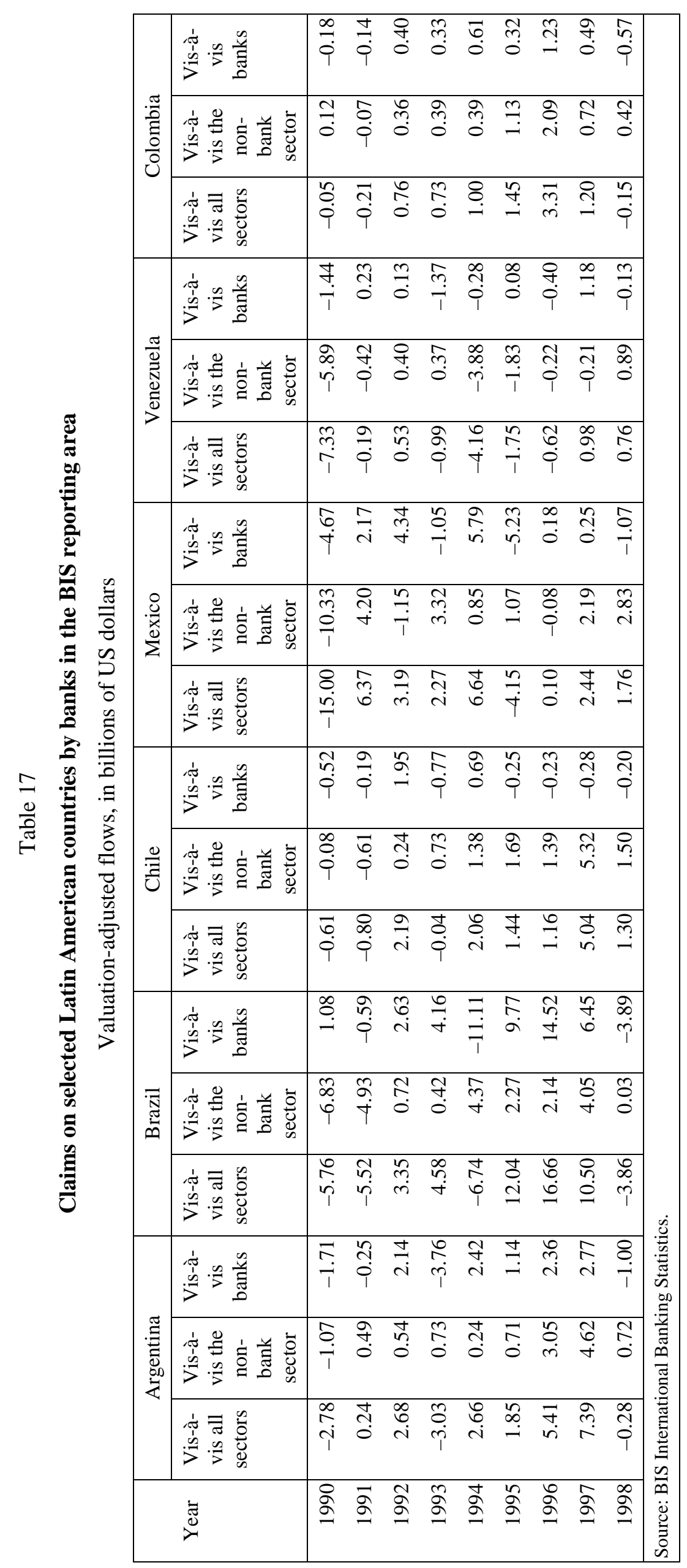


What has characterised so-called "modern international financial crises" has been the enormous growth in international liquidity and the vulnerability of this liquidity to international confidence scares. For a variety of reasons, a large portion of this liquidity was funnelled through the IIBM. Efforts to reduce the risk of international liquidity crises, and the fallout when they occur, would seem to require attention to efforts to improve the structural stability of the IIBM, a question to which we will turn below. What should be asked is whether the "hands off" position of the official sector towards the IIBM and the slow official reaction to the enormous build-up in international liquidity in this market, which emerging market countries used to finance long-term lending, were themselves contributing factors in the Asian crisis. ${ }^{44}$ The moral hazard problem caused by implicit guarantees which many argue was fundamental to the origins of the Asian crisis has origins in both creditor and debtor countries and in both the private and public sectors.

\subsection{Excess liquidity, credit rationing and the risk of interbank market failure}

The standard theory of adverse selection induced credit rationing relies on the simple idea that the composition of the pool of potential borrowers changes with adjustments in interest rates. Because of the inability to perfectly discriminate among potential borrowers, the bank runs the risk that increases in loan rates will attract less creditworthy clients, as less risky borrowers leave the loan market. At this point the expected return declines with additional credit extension. Because the supply of credit does not increase steadily with increases in interest rates, at some point there may be a permanent excess demand. That is, the price of credit cannot be used to clear the loan market. As a consequence the bank rations credit. ${ }^{45}$ Credit rationing essentially means that among two identical borrowers, one may receive credit and the other not. The offer to pay more for a loan will not be satisfied with additional credit supply. The international interbank market provides a good example of credit rationing along these lines but with an additional twist. The lack of information on potential international interbank borrowers is in many cases arguably "compensated for" by an assumed but nonetheless uncertain implicit public guarantee of repayment. This has the effect of increasing the supply of credit to borrowers who might otherwise not receive any in the IIBM.

The build-up of international interbank claims in the industrial world on banks in emerging market countries during the 1990s at first sight stands in some contrast to the standard textbook story of adverse selection related credit rationing. Rather than a state of incipient excess demand in the market, the IIBM appeared to be in a state of a large excess supply. Intense competition, the desire to maintain customer relations, abundant liquidity flowing out of developed economies with large current account

44

Giannini (1999) questions the official position towards the international interbank market.

45 It may be the case that the bank rations credit at any interest rate given that it cannot discriminate perfectly among potential borrowers. See Jaffee and Stiglitz (1990) for a review of the literature. 
surpluses and weak domestic loan demand, coupled with lax monetary policy, drove interest rates and credit spreads down to abnormally low levels. Together with implicit guarantees for interbank credit, acting like a subsidy to borrowing, the incentive structure encouraged "overborrowing" in the IIBM. In this environment, it is reasonable to assume that low interest rates may change the selection of projects otherwise creditworthy borrowers would invest in. Risk preferences may have changed as borrowers become more cavalier given the low cost of funds. At low interest rates projects with high risk but lower expected return may appear attractive. If the level of interest rates alters borrower risk preferences, the supply of credit may be backward bending at both high and low interest rates. Banks may refuse to lend to some willing borrowers at very low interest rates if they think such rates would induce imprudent investment behaviour. Implicit guarantees from governments with good international credit standing might compensate for any reluctance to lend at low rates. Such an environment can be said to have characterised the IIBM during the period 1993 to 1997.

In typical bank loan markets banks may attempt to protect themselves from interest rate induced changes in risk preferences of borrowers by requiring collateral or placing restrictive covenants in loan contracts. In the interbank market concerns with the credit quality of counterparties may induce a shift to lending collateralised with government securities, such as repurchase agreements. Unfortunately, we have little information on the aggregate use of collateral in the market and assume that restrictive covenants are precluded given the short-term nature of the lending and the international character of the loan contract.

The difficulty of restraining the activities of potential interbank borrowers (moral hazard) and the paucity and limited usefulness of balance sheet information (partly as a result of the use of derivatives) increases the need to have some assurance that the interbank borrowing will be repaid. This assurance is all the more necessary given the knowledge that a good deal of short-term interbank borrowing in recent years has been used to fund longer-term investments. The concern with assurances is likely to have risen in view of the surfeit of liquidity awash in international markets during the $1990 \mathrm{~s} .{ }^{46}$ It is also likely that attention to the credibility of implicit guarantees on lending to banks in developing countries was considerable, given that some of the lending banks in the industrial countries had less than outstanding capital ratios themselves.

The picture painted here for the years leading up to the Asian financial crisis is one of considerable excess liquidity in international markets, low interest rates and credit risk spreads, a decline in investor

46

The concern expressed in the "Willard Report" with liquidity and foreign currency mismatches of banks in emerging market countries in part reflects the ease with which liquidity was available in international markets during the decade. The suggestion that the currency mismatch of the banking system should not be "hugely out of line with the potential pool of foreign currency lender-of-last-resort support that is available in the form of foreign exchange reserves plus standby facilities" would for some countries have required very large central bank foreign exchange reserves and standby commitments. The suggestion for countries to establish standby facilities with foreign commercial banks is not new. Dean and Giddy (1981) long ago proposed that the world interbank market emulate the US wholesale loan market in creating a formal network of guaranteed credit commitments. 
International interbank claims on selected countries by banks in BIS reporting area

Valuation-adjusted flows, in billions of US\$
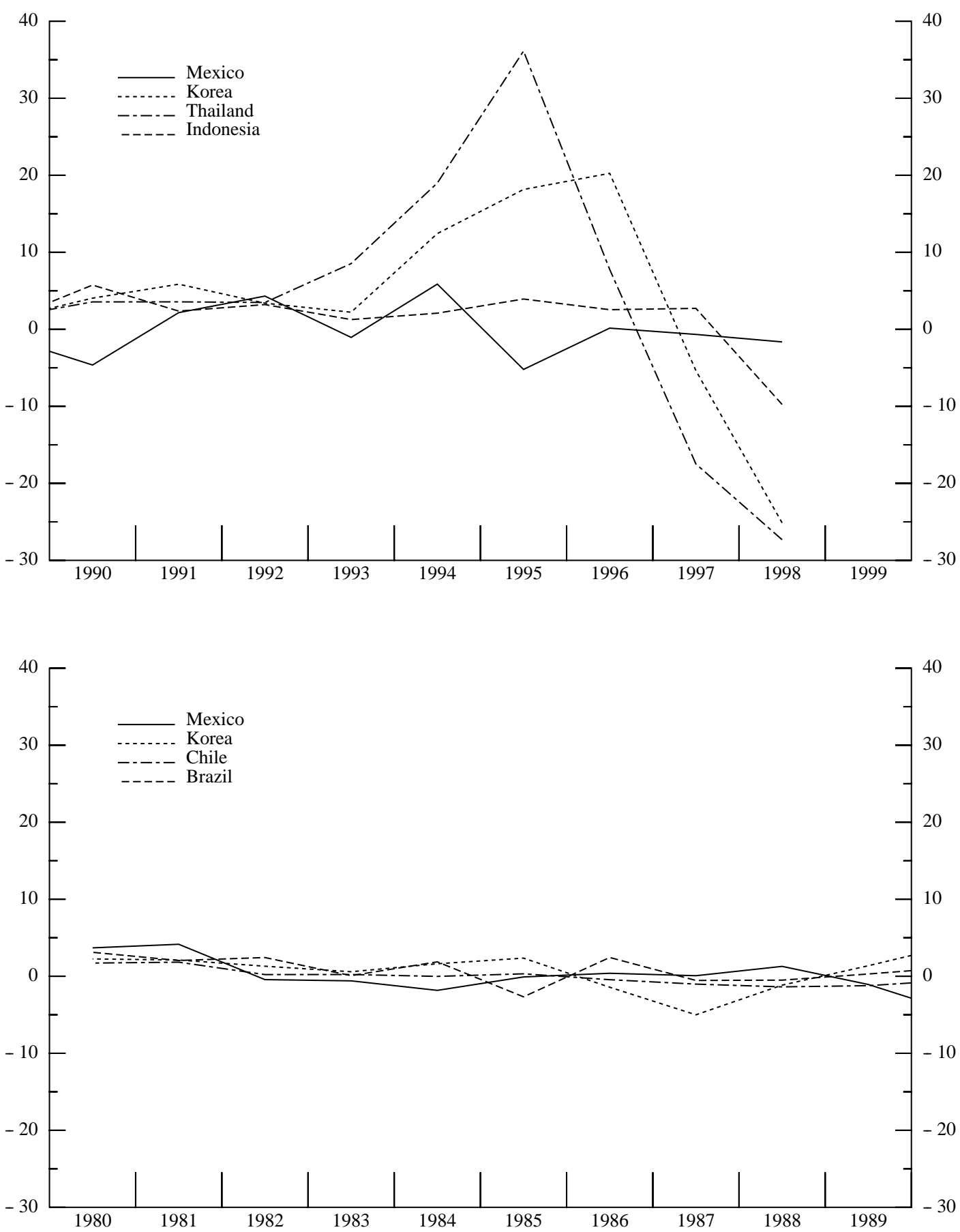

MED Research Group, HJB / 07.03.2000 at 09:09 / Function: INTERBAN-INTERBFLOWS1 


\section{Chart 13}

Interbank claims on selected countries by banks in BIS reporting area and three-month euro-rates
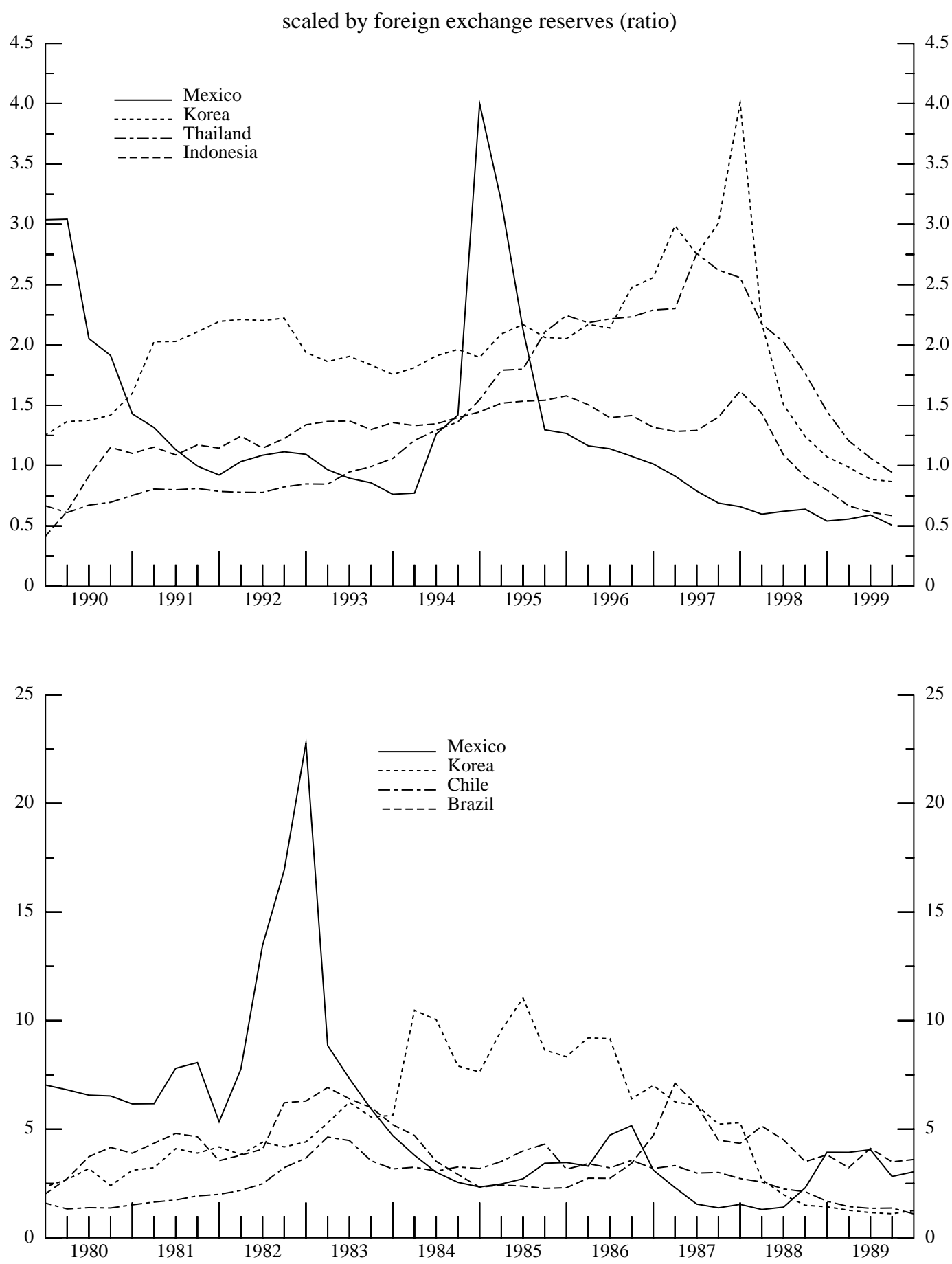

MED Research Group, HJB / 07.03.2000 at 09:14 / Function: INTERBAN-INTERBFLOWS2A 
Interbank claims on selected countries by banks in BIS reporting area and three-month euro-rates

Interest rates on the Euro-market
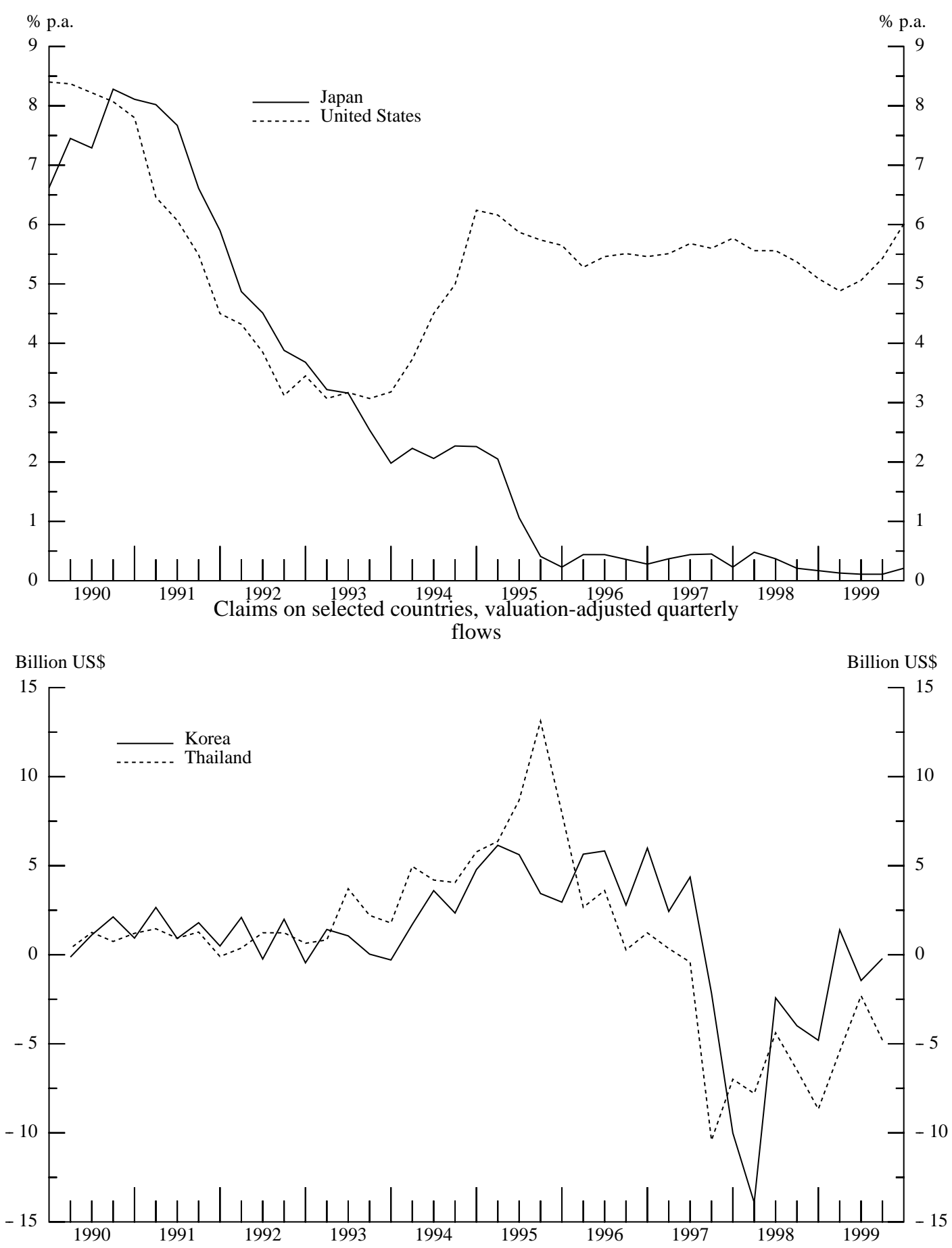
risk aversion, and large interbank exposure to emerging market countries. Emerging market countries in Asia were increasingly relying on inexpensive interbank credit to fund domestic lending, exposing themselves and the market to risk and disruption. What arguably was holding the IIBM together was the widespread opinion of lenders that developing country governments would protect their large banks. ${ }^{47}$ Nonetheless, the risk of interbank market failure was substantial, given the foreign exchange position of the debtor countries. The build-up in interbank claims on developing countries can be seen in Chart 12.

The ratio of interbank claims on emerging market countries to their foreign exchange reserves provides a measure of the vulnerability of both the country and the market. This can be seen in Chart 13 for the period of the 1980s and the 1990s for a selected group of developing countries. The upper panel for three Asian countries and Mexico shows how this ratio built up gradually over several years, particularly for Korea and Thailand. At one point the ratio of interbank borrowing to foreign exchange reserves reached three for Thailand and four for Korea. The bank run nature of the crises can be seen from the dramatic fall in these ratios, as interbank lending declined in 1997. Mexico's vulnerability lay with the foreign currency denomination of short-term government borrowing, which grew substantially between 1990 and $1994 .{ }^{48}$ The level of its interbank obligations grew relatively modestly during this period, as seen in Chart 13, with the increase in the ratio of interbank claims to reserves representing the loss of reserves.

The nature of the imbalances between international interbank debt and available foreign exchange reserves, dramatic as they were, may be understated because of the undisclosed use of reserves. Kim and Rhee (1998) report that before the crisis in 1997 the Korean government used foreign exchange reserves to come to the rescue of foreign subsidiaries of Korean banks which had difficulty rolling over foreign currency obligations. This went unreported since the transfer to the Korean foreign subsidiaries of assets held in foreign banks does not alter the reported foreign exchange reserves. It is unclear if other countries resorted to the same exercise.

The relation between the growth in interbank lending to Asian emerging market countries and liquidity conditions in the industrial countries can be seen by considering the behaviour of interbank interest rates. Three month euromarket rates for dollar and yen both fell in 1991 and 1992. In early 1991 there was a spread of about 2 percentage points which closed around spring 1993. Thereafter the rate on euroyen borrowing fell below eurodollar rates, as US short-term rates rose somewhat and Japanese rates fell sharply after 1994. With the widening of this gap, as seen in Graph 14, interbank borrowing

\footnotetext{
47 See the report on the supervisory lessons drawn from the Asian crisis in Bonte et al. (1999).

48

Chang and Velasco (1998) emphasise the extreme illiquidity in several Asian countries as the origin of the crisis.
} 
by banks in Thailand and Korea began to rise, particularly dramatically for Thailand, surpassing the level of each country's foreign exchange reserves. The large spread was also part of the profitability of the so-called "yen carry trade", which consisted in borrowing short-term in yen and investing the proceeds in higher-yielding non-yen assets, in the United States, Asia and elsewhere.

The incentives for developing countries to borrow heavily in the interbank market and profit from lower interest rates was not unique to the 1990s. Interbank borrowing as a percentage of foreign exchange reserves was also high in the 1980s, as seen in the lower panel of Chart 13. Moreover, the spread of short-term eurodollar over yen rates was very large between 1981 and 1984. Countries such as Chile, Mexico, Argentina, Columbia, Brazil and Venezuela all borrowed heavily in the interbank markets, much of it from the United States, although the dollar volume of these flows looks modest in comparison with interbank lending to Asia in the 1990s. The fallout from the 1982 Mexican debt crisis on the interbank market was considerable, displaying the instability of a market which clears by dramatic adjustments in credit lines. According to Clarke (1983), international interbank claims of US banks on Latin America fell sharply between 1982 and 1983. Claims on Mexico, which had grown by $49.6 \%$ between mid-1981 and mid-1982, fell by $1.9 \%$ by mid-1983. US interbank claims on Brazil, Chile and Peru similarly fell in 1983, after growing strongly in 1982. It was this type of wrenching in interbank flows to developing countries which public officials have since tried to avoid.

Following the Asian financial crisis there has been a renewed call for efforts to stabilise international financial flows, including increasing monitoring of countries' short-term foreign currency indebtedness, the greater use of contingent credit lines and a lengthening of the maturity of private and public sector foreign currency liabilities. However, the attractiveness of foreign short-term credit is difficult to dampen when it is available in the quantities observed in the 1990s and at rock bottom interest rates. In retrospect, greater attention should have been given to the build-up in international credit supply and the vulnerability of a market subject to significant credit rationing and implicit guarantees. $^{49}$

\subsection{When private liquidity markets collapse}

In the past financial authorities have placed considerable emphasis on the need to assure the stability of the international interbank market and desired not to impede its development. Before 1988 many countries independently placed lower capital requirements on interbank lending than on commercial credits. $^{50}$ The same was true (of short-term interbank lending) in 1988 when the Basel Capital Accord was established. Official intervention in international financial crises has repeatedly emphasised the

49 The official concern with the lengthening of maturities of foreign currency indebtedness of developing countries has emphasised public and non-financial private sector indebtedness, with only modest attention to the interbank market.

50

Guttentag and Herring (1985), p. 31. 
importance of maintaining the stability of this market. The 1998 Report of the Working Party on Strengthening Financial Systems, under the rubric of the need to provide liquidity assistance in conditions of stress, stated as an objective the need "to protect the integrity of the payment system and ensure continued interbank funding" (p. 22).

A fundamental question is why the IIBM at times shows signs of an inherent instability. Above we have emphasised the problem of information asymmetries, including adverse selection and moral hazard. ${ }^{51}$ Yet even before these factors we would emphasise the state of aggregate excess international liquidity during much the 1990s which sowed the seeds of the subsequent eruption of illiquidity. The apparent failure to adequately monitor both aggregate international liquidity and the short-term foreign currency obligations of emerging market countries in relation to their accessibility and supply of foreign exchange reserves contributed to the build-up of the Asian financial crisis.

The inherent instability in the IIBM is also related to the interrelationship between the disclosure policies of international banks and the implicit official support assurances given them. ${ }^{52}$ Official reports going back to the 1980s point to the lack of incentives to monitor banks borrowing in the IIBM. $^{53}$ On the surface the incentive to improve monitoring would appear substantial. Following both the Latin American debt crisis in 1982 and the 1997 Asian financial crisis industrial country bank share prices declined relative to the overall market index, as seen in Chart $15 .^{54}$ Recent efforts by official institutions to improve disclosure and peer monitoring in banking are in part a recognition of the speed with which some financial markets can lose liquidity literally overnight. An important question is whether official guarantees have reduced the incentives to monitor counterparty risk in the international interbank market. Central bankers are increasingly of the opinion that this is a serious problem, and, as recently expressed by Federal Reserve Chairman Alan Greenspan, the IIBM represents the "Achilles' heel of the international financial system":

"Creditor banks expect claims on banks, especially banks in emerging economies, to be protected by a safety net and, consequently, consider them to be essentially sovereign claims. Unless these expectations are substantially altered - as when banks actually incur significant losses - governments can be faced with the choice either of validating those expectations or of risking serious disruption to payments systems and to financial markets in general." (Greenspan (1998)).

51 An additional problem is that of ex post "costly state verification", the need for the lender to incur a cost to discover the true reason for the investment outcome of the borrower.

52 Guttentag and Herring (1986) argue that voluntary disclosure is not adequate to provide investors and creditors with sufficient information to make sound investment decisions.

53 We are not implying that some tiering in the IIBM does not occur.

54 Cornell and Shapiro (1986) found that the returns to US money centre banks fell significantly as a consequence of their exposure to Latin America in 1982 and 1983. They found that even in the absence of detailed public information on individual bank exposure to Latin America the market was able to differentiate between banks with different degrees of exposure. 
Stock market index of banks in relation to whole market
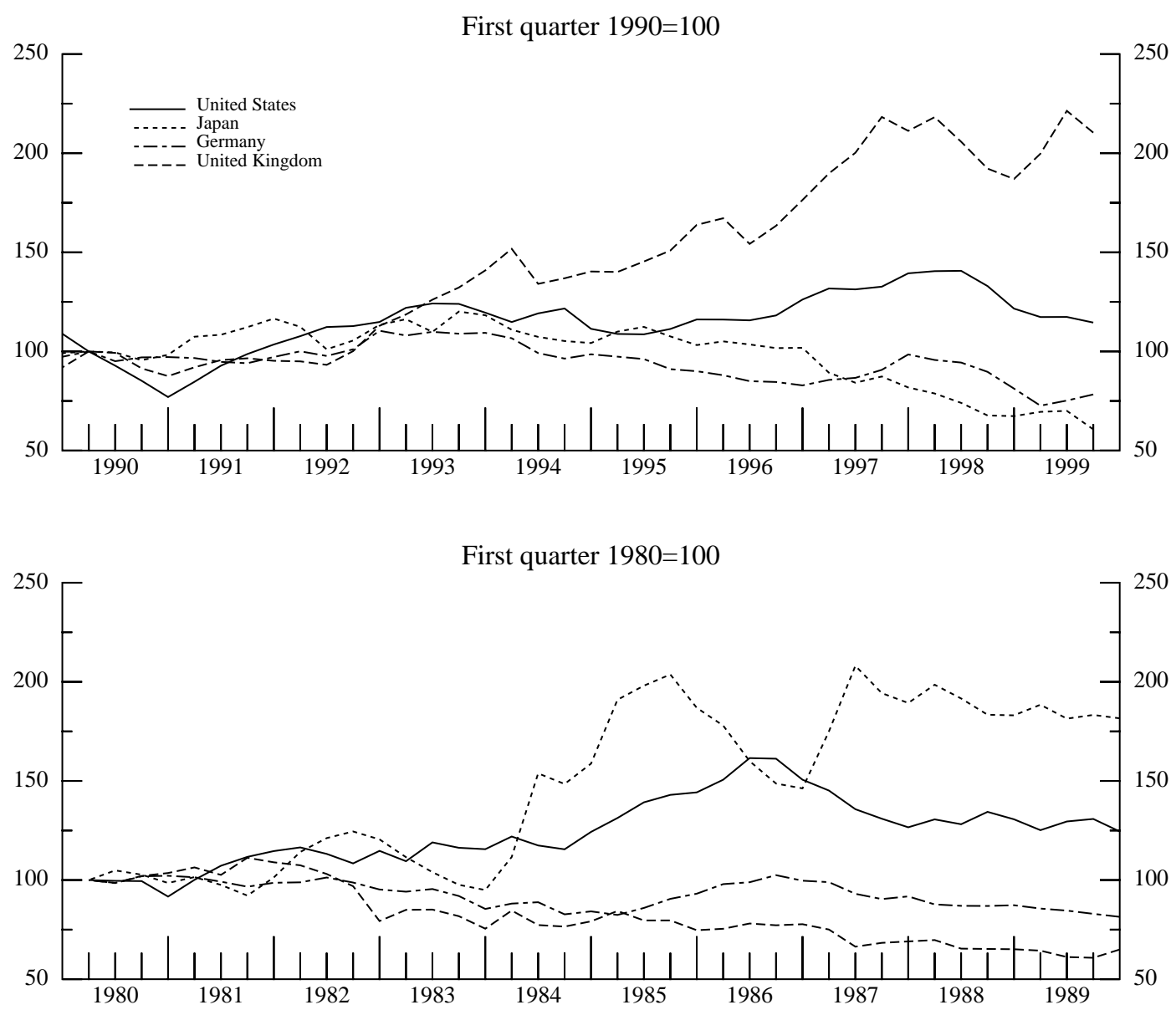
A measure of the potential liquidity problem in the IIBM was seen in the Asian turmoil. The Willard Report (1998, p. 13) noted that at the end of 1997 of the $\$ 380$ billion of international bank lending to Asian countries, mostly in foreign currency, $60 \%$ had a maturity of less than a year. It was their view that much of the short-term foreign currency lending to Asian countries was used to finance long-term projects which did not produce income in foreign currency sufficient to retire maturing foreign currency debt. ${ }^{55}$

To understand the origins of the large flight of interbank lending to banks in several Asian countries following the outbreak of the crisis in 1997 it is useful to consider the factors which might cause a market in liquidity, in particular the interbank market, to "collapse". In doing so it is important to remember the considerable dependence the private sectors of many developing countries have on bank credit and the immature nature of their capital markets.

Our explanation of the vulnerability of the markets in liquidity to collapse rests on the interaction of several factors: the importance of information asymmetries in very short-term financial markets, the need to provide implicit insurance to information-deficient banks to sustain liquidity inflows, the "underpricing" of what is essentially, even if implicit, international deposit insurance and the paucity of short-term contingent credit facilities in the interbank market. The literature we might lean on to understand these issues is rich and interrelated. ${ }^{56}$ But of overriding importance is the vulnerability of informationally deficient markets in liquidity with large implicit government guarantees. Our point is that such markets are fundamentally unstable and subject to "attack", in the sense that the private sector (those institutions which benefit from the guarantee) will attempt to leverage the (zero-priced) insurance by engaging in profitable maturity and currency mismatches. In addition to engaging in such transformations, the international interbank market is also performing a risk transformation, in transferring liquidity from banks with higher credit ratings to those with lower credit status. ${ }^{57}$ Just as an exchange rate peg can provide a one-way bet for speculators (a price-fixing objective), so zero-cost insurance on private liabilities provides the quantity counterpart. The official objective of maintaining liquidity in a market at all costs will encourage some investors to assume that liquidity will almost always be readily available. Participants thus have a strong incentive to underinvest in liquid assets. Given the proliferating demands for liquidity from a variety of domestic and foreign markets, mentioned at the beginning of this paper, these assurances are likely to be increasingly difficult to

55 As shown by Kletzer (1984) short-maturity developing country debt is a direct equilibrium consequence of the absence of enforceable constraints on borrowers' ability to dilute the value of lenders' claims.

56 The interrelationship we would like to point to is that between the literature on information asymmetries in financial markets (Akerlof (1970), Stiglitz and Weiss (1981), Ordover and Weiss (1981), Mankiw (1986), Allen and Saunders (1986)) and that on speculative attacks on markets with government guarantees (Salant and Henderson (1978), Salant (1983), Krugman (1991), Dooley (1997)).

57 Dematté (1981) noted the risk transformation taking place in the interbank market. 
satisfy. ${ }^{58}$ Liquidity crises may be an increasingly common feature of the international financial environment. The interbank market is hence both more important in satisfying shifting global liquidity needs and itself a source of liquidity shocks.

In the face of an unanticipated liquidity shock the interbank market might "collapse", in the sense that lenders, increasingly unable to distinguish between a large (or larger) class of heterogeneous risky borrowers, may refuse credit to all of them. One shock may simply be changes in the external (world) interest rate. The rise in rates increases the borrowing cost for lenders (increasing their required rate of return). This by itself may make the market collapse given that the expected return from lending does not rise continuously with an increase in rates. ${ }^{59}$ Several studies have uncovered a considerable sensitivity of emerging market lending to world interest rates. If increases in rates reduce the number of potential creditworthy borrowers the adverse selection problem may simply cause lenders to increasingly refuse credit and in extreme cases of information asymmetry refuse finance to all applicants with similar risk characteristics (e.g. regional emerging market borrowers). Good borrowers may also have difficulty signalling their credit quality to lenders and be shut out of the credit market as well. ${ }^{60}$

This inherent vulnerability of the interbank market to collapse is one of the reasons the IIBM arguably needs to be supported by some kind of government intervention. It is in this light that we interpret the finding of the 1992 study of the IIBM by G10 central banks that "the confidence with which this conviction is held (the belief that central banks or public authorities would act to prevent any disruption from reaching systemic proportions) acted to stabilise markets" (p. 19). The internationalisation of financial markets has increased the problem of international adverse selection. In a domestic context Allen and Saunders (1986) recognised that the US federal funds market was subject to potential segmentation between large and small banks and the potential for exclusion of some banks from the market due to adverse selection. They have argued that implicit long-term contracts can potentially resolve this problem. However, for some borrowers it may be difficult and very costly to signal their true default risk (i.e. the rate offered them if their true risk was known might make borrowing prohibitive). These borrowers would need some sort of assistance in order to enter the market.

We can think of the implicit guarantee given to potentially risky borrowers in the IIBM as essentially a subsidy which helps to assure the viability of the market. In principle, it is similar to the subsidy which is provided in markets with extreme adverse selection problems. Mankiw's (1986) example of a

\footnotetext{
58 The assumption of liquidity availability was apparent in the recent LTCM crisis and the Asian financial crisis. Both crises required official intervention.

59 See Mankiw (1986) for a simple example of adverse selection and credit market collapse.

60 Allen and Saunders (1986).
} 
government student loan guarantee as a subsidy which reduces the adverse selection problem is useful here. For certain classes of IIBM borrowers the absence of the implicit guarantee would, at some interest rate, exclude them from the market. With the subsidy the extra investment generated by IIBM borrowing is potentially socially beneficial and indirectly helps in contributing to growth to pay for the subsidy. Without the implicit guarantee the heterogeneity of emerging market borrowers would probably cause the market to collapse at some interest rate and socially productive investment would not take place. Thus to justify the need for implicit guarantees in the interbank market requires that the expected returns from the extra investment be greater than the cost of the subsidy. However, the subsidy could also lead to the "overconsumption" of inexpensive short-term credit.

Asian emerging market economies which borrowed heavily in the IIBM starting around 1993, in particular Korea and Thailand, were relatively new to the world of deregulated finance, a fact well known to banks lending to them. It is likely that, had strong implicit guarantees not been in place, much less borrowing would have occurred. The ready availability of plentiful interbank funding essentially set up the potential attack on the (implicit) "insurance fund", not much different from the attack by the US savings and loan institutions on their explicit insurance fund. ${ }^{61}$

The argument made here is simple enough. Without some form of "subsidy" it is likely that the IIBM would be closed to many banks in emerging market countries. Some segments of the market would simply collapse. The information asymmetries and potential adverse selection problems would just be too great to warrant lending. This subsidy is not explicit, however, because making it so, would potentially make the "moral hazard" problem unmanageable, in the sense that the grantor of the subsidy could not control the behaviour of the receiver of the subsidy. Nonetheless, the current incentives are for receivers of the subsidy to leverage it as far as possible. The government can prevent abuse of the subsidy only if in some manner it can influence lending and borrowing in the IIBM, when additional borrowing begins to reduce the probability of repayment, for example where the foreign currency exposure of the banks presents a potential threat to the country's foreign exchange reserves.

The provision of subsidies in the form of government guarantees designed to mitigate the adverse selection ("lemons") problem appears in a number of areas of both domestic and international finance. Export credit guarantees is one of the most obvious. Those who argue that the implicit guarantee in the IIBM should somehow be removed fail to recognise that without it the equilibrium in the interbank market would be even more precarious than it currently is. But there lies the dilemma. With the implicit subsidy, permitting the formation of implicit multi-term contracts between interbank lenders in industrial countries and borrowers in developing countries, and without close monitoring of the interbank borrowing, the "implicit insurance fund" provided by the country of the borrowing bank,

61 This is the point made by Dooley (1997) along the lines of the Akerlof and Romer (1993) theory of "looting". See also Bisignano (1999). 
and in extreme cases the international community, is subject to attack. In short, for some countries without the "subsidy" the market is subject to collapse, but with it the subsidy is likely to be abused.

This line of argument suggests that the liquidity crises observed in Asia and elsewhere, where related to the international interbank market, are unlikely to be prevented by simply establishing an international lender of last resort (ILLR). An ILLR would do nothing to resolve the fundamental vulnerability of the interbank market and might even contribute to anticipated attacks on the "insurance fund". The analogy between a domestic LLR and an ILLR weakens when we consider the differences in asymmetric information and adverse selection problems and the absence of international supervisors and universal bank closure rules. ${ }^{62}$ To minimise the need for international liquidity assistance requires that we first address the issue of how to control the provision of a subsidy to the international deposit market and its consumption.

\section{Resolving the problem of the abuse of implicit guarantees in the IIBM}

\subsection{Externalities and deposit guarantees without ex ante guarantors: a public economics perspective}

The liquidity problems observed in the Asian crisis led to a variety of calls for measures to reduce liquidity risk in the international financial system. These include discouraging short-term public and private debt denominated in foreign currencies, the provision of contingent short-term bank credit facilities for international borrowers, limiting government guarantees to the private sector, and the establishment of a global lender of last resort. The Report of the Working Group on International Financial Crises (1998) considered a number of such suggestions for preventing crises. Many of these proposals have been around in the past and are now resurfacing. Dean and Giddy (1981) proposed that the international interbank market establish formal, guaranteed credit commitments among its participants. Grubel (1979) suggested the creation of an international deposit insurance corporation. Franklin Edwards, cited in Dean and Giddy (1981), and many others later, proposed the creation of an international lender of last resort.

A refrain repeatedly heard in almost any discussion of the Asian crisis is the need to minimise government guarantees to the private sector. This was a clear message of the recent Report of the

Dooley (1997) is correct in suggesting that the way of reducing international liquidity insurance crises is to limit the access to insurance which an ILLR would represent. Dean and Giddy (1981) recognised some time ago that while official international funding support might reduce global risk and the likelihood of bank runs, it could also reduce international stability the more readily such funding was provided. 
Working Group on International Financial Crises (1998). ${ }^{63}$ It should be recognised that in a number of financial systems implicit deposit guarantees play a major role in securing stability, even when there is an explicit deposit insurance programme in place. Japan is a good example. Although established in 1971, Japan's deposit insurance system and its formal safety net played little if any role in the governance of bank failure. Implicit government deposit insurance and a "silent partnership" between the public and private sectors supported a "no failure norm" in the banking system (Milhaupt (1999)). In addition, the regulatory structure was designed in such a manner as to support this implicit safety net. Similar systems can be said to exist in a number of countries where capital markets remain underdeveloped. While it is easy to be critical of such systems, given the existing financial structure (i.e. bank-dependent), the stability they impart should not be ignored. It can be argued that the IIBM functions in a similar manner with a "no failure norm", with positive, and at times negative, externalities.

Our point of departure is that, sound as the suggestion to eliminate implicit guarantees is, it is unlikely to occur any time soon, particularly for the international interbank market. Indeed, the threat by official institutions not to come to the assistance of the interbank market is difficult to make credible. At least for some segments of the IIBM, implicit guarantees will remain in order to prevent market failure. No doubt the adverse selection problem in the market can be reduced with greater information disclosure and improved corporate governance in the banking sector of developing countries. But much of the problem will remain. The focus of debate might profitably be shifted to how to manage guarantees in the interbank market. The Asian financial crisis, and several in Latin America before it, should be viewed from the vantage point of the mismanagement of a government guarantee, without which the market in international liquidity for developing countries could potentially collapse.

The subject of liability guarantee management raises the question of why the implicit guarantee exists in the first place. To understand this we can use arguments from the theory of public economics. This perspective suggests that the IIBM provides positive externalities to the international financial system. The market contributes to international financial stability by increasing the efficiency of global liquidity allocation. Institutions which neither provide nor utilise this liquidity nonetheless profit from its provision and consumption by others. The positive externalities justify government subsidies.

The implicit subsidy in the IIBM has the effect of lowering the international cost of credit and expanding international liquidity. However, because of the implicit nature of the subsidy it is determined endogenously by consumers and producers of international liquidity. Without some restraint on its provision it is at times likely to be "oversupplied", lending to excess liquidity and an

63 One section of this report, the "Report of the Working Group on Strengthening Financial Systems", noted the need to "ring-fence the socialisation of risk and to limit forbearance". Procedures to do so require that "the incentives facing market participants are not unduly distorted, for example, by a widespread expectation that all bank liabilities ultimately have state underpinning" (p. 21). 
abnormally low price of interbank credit. Moral hazard results from the inability of governments to control the provision of the subsidy to the IIBM and its consumption.

The interbank market can also be the source of negative externalities when a liquidity shock occurs, such as the contagion which afflicts countries not directly responsible for a regional financial crisis. We attempted to measure this contagion earlier. Negative externalities can be influenced by taxes, fines or regulation. Those who potentially contribute to the abuse of the subsidy and the negative externality should then be subject to some tax, fine or regulation. ${ }^{64}$

We would argue that the IIBM is subject to a large subsidy and, in various guises, costs and regulation, such as capital requirements on international interbank lending. However, the stated objective of not excessively interfering with the functioning of the IIBM arguably may have led to the inefficient management of the implicit international deposit guarantee. We need to ask how we might counter excessive provision and consumption of an implicit international liability guarantee which periodically leads to excessive international liquidity and credit expansion, an underprovision of monitoring of credit risk and, in severe cases, financial crisis requiring official intervention.

Our first problem in considering international deposit guarantee management is that there is no ex ante guarantor; the insurance is implicit. The insurance is contingent on there being a significant enough crisis such that government or international official intervention is required. The second problem is the need to impose some cost on those who benefit directly from the subsidy.

\subsection{A variation on the Merton-Bodie paradigm of the management of guarantees}

A number of commentators on the Asian financial crisis have remarked on the need to improve cost sharing by the private sector after the onset of financial crisis. Although holders of longer-term claims on developing countries (equity and bonds) have frequently suffered losses, short-term claim-holders often escape relatively unbruised. This was true in the 1995 Mexican crisis involving government Tesobono securities and with international interbank credit in the Asian crisis. ${ }^{65}$ Anticipated implicit guarantees on very short-term international debt often turn out to be real guarantees. Goldstein (1998) argues that of the many criticisms levelled at the design and effectiveness of IMF rescue efforts only one has any substance: "the moral hazard problem linked to bailing out large uninsured creditors of banks in the crisis countries" (p. 32).

Robert Merton and Zvi Bodie (1992) have proposed a simple characterisation of the management of government liability guarantees which includes monitoring, asset restrictions and risk-based liability premiums. They argue that each of these mechanisms for guarantee management was absent in the US

\footnotetext{
64 See Stiglitz (1986) on externalities and public policy and Furman and Stiglitz (1998) on policies to restrain capital flows.

65 See Herring (1999).
} 
savings and loan industry, contributing to the crisis. The expanded powers which were granted S\&Ls in the name of deregulation, much like the increased powers given Asian emerging market countries in the name of "international financial liberalisation", led to a rapid expansion in their liabilities. The lack of incentives to monitor these institutions, the relaxation of restrictions on their investment behaviour and the underpricing of deposit insurance eventually led to the collapse of the industry. Similar parallels hold in several emerging market countries.

In a domestic context, improved monitoring can occur from the marking-to-market of the assets and liabilities of the insured institution. This is obviously a contentious issue in banking and more so for developing countries. In addition, without knowledge of the true net worth of the insured institution and appropriate legal recourse it would also be difficult to seize collateral. Nonetheless, increased disclosure could be demanded of borrowers in the IIBM. There might also be a move to require a greater use of collateral for interbank borrowing dependent on the quality of disclosure. The monitoring of banks and their investments is difficult in a domestic context and is at least doubly so in an international one. Moreover, the incentives to monitor may be dampened by the knowledge that, for economically and politically important countries, creditor and debtor governments may come to their assistance. The incentive to monitor could be increased, however, if those who might potentially benefit from liability guarantees have to pay for them.

The logic of risk-based liability insurance is clear, even if the practical problems of implementation are complex. Insurance premiums should be related to risk exposure. The US proposed the use of riskbased deposit insurance in its Federal Deposit Insurance Corporation Improvement Act (FDICIA) financial legislation passed in 1991. Presumably the higher cost of deposit insurance is reflected in lending rates and the returns given to depositors. Risk-based insurance premia, however, are obviously difficult to impose when the guarantor is unknown. However, the premium can nonetheless be levied when the insured institution makes itself available to the guarantee by appealing for official liquidity assistance. In the case of cross-border interbank lending the premium can potentially be paid by the beneficiary of the guarantee, the international depositor. Hence the beneficiary of the implicit subsidy is required to absorb the cost of its provision. ${ }^{66}$

The implementation of an ex post charge for liability insurance could be triggered, for example, when official international assistance is required to resolve a country's financial crisis (e.g. the granting of an IMF standby agreement). Interbank lenders could then be charged an ex post insurance premium

66

A related issue to that of ex post deposit liability insurance is that of the role of risk-based capital regulation. Under certain conditions it has been shown that bank capital regulation may not deter banks from selecting risky asset portfolios. Where banks are concerned with the maximisation of future profits Rochet (1992) has shown that risk-based insurance premia may be preferable to capital regulation. 
related to their withdrawals, in other words a "haircut". ${ }^{67}$ While such a mechanism of liability guarantee management might lead to greater risk premia in interbank lending rates, something which many previously thought undesirable, we interpret this as a means of managing implicit guarantees by market forces. Greater ex ante risk discrimination in the IIBM may have the effect of making the market less vulnerable to liquidity shocks and contagion.

If ex post deposit liability guarantee premiums are thought undesirable or impractical and monitoring is considered by the official community to be inadequate, another course of action would be asset restrictions on the guaranteed institution. Asset restrictions can be placed on both the investments of the borrower and the interbank activity of lending institutions. These restrictions can be interpreted as measures needed to ensure the solvency of the implicit "insurance fund". Any such restrictions would be likely to require considerable international regulatory cooperation and agreement.

Many of the proposals which have been put forward to prevent future financial crises have dealt with attempting to reduce the exposure to potential capital flight by changing developing country debt structure (e.g. lengthening of maturities of public and private foreign currency liabilities) or reducing adverse selection (e.g. greater public and private sector financial disclosure). Few have dealt with the problem of the management of the implicit guarantee which hangs over short-term international interbank lending. This lending is taking place subject to large unpaid insurance coverage, which can be measured by the official financial assistance recently required to resolve the Asian crisis. Sizeable interbank losses by a major international bank are unlikely to discourage the kind of lending we observed to emerging market countries during the 1994-97 period, when international liquidity was in plentiful supply. Without the management of implicit interbank liability guarantees expectations of further bailouts are likely to predominate as soon as the next crisis erupts.

\section{Conclusion}

In this paper we have emphasised the interrelationship between information, liquidity and risk in the international interbank market and the role this market has played in the build-up to the Asian financial crisis. The IIBM has been a source of considerable instability to international capital flows as a result of the credit rationing behaviour of lenders. We noted the policy dilemma of having to provide an unannounced but clear implicit subsidy to the market to ensure its stability because of the severe information problems which exist in international liquidity lending and at the same time the difficulty of controlling the consumption of this subsidy by international interbank lenders and borrowers. Rather than continue to simply lament the problem of moral hazard which exists in the international

67 There has been some official discussion of the possibility of placing call options in interbank credit lines, giving debtors the right to delay repayment. It apparently has not been met with great support. See Chote (1999). 
interbank market, we propose that the debate be shifted to how best to manage implicit international deposit guarantees. Three means are available: greater disclosure by borrowing institutions, an action which addresses the adverse selection problem; asset restrictions on borrowers, which addresses the moral hazard issue; and ex post risk-based deposit insurance, which can influence the market discipline of lenders. The last of these three alternatives is arguably the most difficult to address because the guarantee is neither explicit nor is it obvious how and by whom any ex post deposit premium should be levied. Yet it is clear that the IIBM is supported by individual governments and official international organisations and that these unmanaged implicit guarantees have been instrumental in periodically causing a misallocation and an excessive expansion in interbank lending. Without some means of inducing greater discrimination and monitoring in the IIBM via market discipline and an equitable allocation of charges on those who benefit from international liability guarantees, the interbank market will continue to be a large contributor to short-term international capital flow volatility.

Considerable and repeated mention had been made in recent years of the need to reduce moral hazard, broadly defined, in the international financial system. Yet few of the recent proposals which have been put forth address the specific issue of international deposit insurance. Morris Goldstein (1998, p. 46) has argued that an important action needed to reduce moral hazard would be "to encourage emerging economies to adopt a system of deposit insurance that is incentive compatible and that places large, uninsured creditors of banks in the back of the queue when failed banks are resolved". He suggests looking at recent US banking legislation, specifically the FDICIA, for ideas on how to make it more difficult for regulators to bail out large uninsured bank creditors. While this suggestion merits consideration, we also need to recognise the need for an efficient international interbank market and the role of implicit guarantees. The positive externalities which flow from the IIBM are important enough to merit the implicit subsidies/implicit guarantees it receives. Greater attention might now be paid to how the international financial community might best manage the subsidy it is clearly providing. 


\section{References}

Agenor, Pierre-Richard and Joshua Aizenman (1998): "Contagion and volatility with imperfect markets". International Monetary Fund Staff Papers, June.

Akerlof, George A (1970): "The market for lemons: quality uncertainty and the market mechanism". Quarterly Journal of Economics.

Akerlof, George A and Paul M Romer (1993): "Looting: the economic world of bankruptcy for profit". Brookings Papers on Economic Activity, No. 2.

Allen, Linda and Anthony Saunders (1986): "The large-small bank dichotomy in the federal funds market", June.

Bacha, Edmar Lisboa and Carlos F Diaz Alejandro (1982): "International financial intermediation: a long and tropical view". Essays in International Finance, No. 147, Princeton University, May.

Baig, Taimur and Ilan Goldfajn (1998): "Financial market contagion in the Asian crisis". IMF Working Paper No. 98/155, International Monetary Fund, November.

Bank for International Settlements (1983): "The international inter-bank market: a descriptive study". ("Holland Report"), BIS Economic Papers No. 8, July.

Bank for International Settlements (1992): "Recent developments in international inter-bank relations". ("Promisel Report"), report prepared by a Working Group established by the central banks of the Group of Ten countries, October.

Bester, Helmut (1985): "Screening vs. rationing in credit markets with imperfect information". The American Economic Review, September.

Bhagwati, Jagdish (1998): "The capital myth: the difference between trade in widgets and dollars". Foreign Affairs, May/June.

Bhattacharya, Sudipto and D Gale (1987): "Preference shocks, liquidity and central bank policy", in New Approach to Monetary Economics, W.A. Barnett and K.J. Singleton, (eds.). Cambridge University Press.

Bhattacharya, Sudipto and Paolo Fulghieri (1994): "Uncertain liquidity and interbank contracting". Economic Letters.

Bisignano, Joseph (1999): "Precarious credit equilibrium: reflections on the Asian financial crisis", in The Asian Financial Crisis: Origins, Implications, and Solutions, William C Hunter, George G Kaufman and Thomas H Krueger (eds.), Kluwer Academic Publishers.

Bonte, Rudi et al. (1999): "Supervisory lessons to be drawn from the Asian crisis". Basel Committee on Banking Supervision Working Papers No. 2. Bank for International Settlements, June.

Calvo, S and C M Reinhart (1997): "Capital flows to Latin America: is there evidence of contagion" in Calvo, Goldstein, and Hochreiter (eds.), Private Capital Flows to Emerging Markets after the Mexican Crisis, Institute for International Finance, Washington, D.C.

Chadha, Bankim and David Folkerts-Landau (1997): "The evolving role of banks in international capital flows". Paper presented at the Conference on International Capital Flows, sponsored by the NBER, Woodstock, Vermont, 17-18 October.

Chang, Roberto and Andrés Velasco (1998): "Financial crises in emerging markets: a canonical model". NBER Working Paper, No. 6606, June.

Chote, Robert (1999): "IMF wants private sector to help resolve crises". Financial Times, 16 April.

Clarke, Stephen V O (1983): "American Banks in the International Interbank Market". Salomon Brothers Centre for the Study of Financial Institutions, New York University. 
Cline, William R and Kevin J S Barnes (1997): "Spreads and risks in emerging markets lending". IIF Research Papers No. 97-1, Institute of International Finance, Inc.

Cornell, Bradford and Alan C Shapiro (1986): "The reaction of bank stock prices to the international debt crisis". Journal of Political Economy, February.

Corsetti, Giancarlo, Paolo Pesenti and Nouriel Roubini (1999): "Paper tigers? A model of the Asian crisis". European Economic Review.

Dean, James W and Ian H Giddy (1981): "Averting International Banking Crises". Monograph 19811, Salomon Brothers Center for the Study of Financial Institutions, New York University.

Dematté, Claudio (1981): "International financial intermediation: implications for bankers and regulators". Banco Nazionale del Lavoro Quarterly Review, March.

Dooley, Michael P (1997): "A model of crises in emerging markets". NBER Working Paper No. 6300, December.

Ellis, David M and Mark J Flannery (1992): “Does the debt market assess large banks' risk: time series evidence from money centre CDs". Journal of Monetary Economics.

Fernandez-Arias, Eduardo (1996): “The new wave of private capital inflows: push or pull?" Journal of Development Economics.

Fischer, Stanley (1998): "Capital-account liberalisation and the role of the IMF", in "Should the IMF pursue capital-account convertibility?" Stanley Fischer, et al., Essays in International Finance No. 207, Princeton University, May.

Flannery, Mark J (1996): "Financial crises, payment system problems, and discount window lending". Journal of Money, Credit and Banking, Part 2.

Folkerts-Landau, David (1985): "The changing role of international lending in development finance". IMF Staff Papers, International Monetary Fund, June.

Freixas, Xavier and Jean-Claude Rochet (1997): "Microeconomics of Banking". The MIT Press, Cambridge, Massachusetts.

Furman, Jason and Joseph E Stiglitz (1998): "Economic crises: evidence and insights from East Asia". Brookings Papers on Economic Activity, No. 2.

Giannini, Curzio (1999): "Enemy of none but a common friend to all: an international perspective on the lender of last resort function". IMF Working Paper No. 99/10, International Monetary Fund, January.

Giddy, I H (1981): "Risk and return in the Eurocurrency interbank market". Greek Economic Review, August.

Goldstein, Morris (1998): “The Asian finance crisis: causes, cures and systemic implications". The Institute for International Economics, Washington, D.C.

Greenspan, Alan (1998): "Remarks at the 34th Annual Conference on Bank Structure and Competition". Federal Reserve Bank of Chicago, 7 May.

Group of Ten (1996): "The Resolution of Sovereign Liquidity Crises". A report to the Ministers and Governors prepared under the auspices of the Deputies, May.

Grubel, Herbert G (1979): “A Proposal for the Establishment of an International Deposit Insurance Corporation". Princeton Essays in International Finance No. 133, July.

Guttentag, Jack and Richard Herring (1985): "Funding risk in the international interbank market", in International Financial Markets and Capital Movements: A Symposium in Honour of Arthur I Bloomfield. Wilfried J Ethier and Richard C Marston (eds.), Essays in International Finance No. 158, Princeton University, September. 
Guttentag, Jack and Richard Herring (1986): "Disclosure policy and international banking”. Journal of Banking and Finance, March.

Guttentag, Jack and Richard Herring (1987): "Emergency liquidity assistance for international banks", in Threats to International Financial Stability, R Portes and A Swoboda, (eds.), Cambridge University Press.

Herring, Richard J (1985): "The interbank market”, in Eurodollars and International Banking, Paolo Savona and George Sutija, (eds.), Macmillan.

Herring, Richard J (1999): "Comment on "Asian Crisis: Causes and Remedies", in The Asian Financial Crisis: Origins, Implications, and Solutions, W C Hunter, G G Kaufman, and T H Krueger, (eds.), Kluwer Academic Publishers.

Institute of International Finance, Inc. (1999): "Report of the working group on financial crises in emerging markets". Washington, D.C., January.

Ito, Takatoshi (1999): “Capital flows in Asia”. NBER Working Paper No. 7134, May.

Jacklin, Charles and Sudipto Bhattacharya (1988): "Distinguishing panics and information-based bank runs: welfare and policy implications". Journal of Political Economy, June.

Jaffee, Dwight and T Russell (1976): "Imperfect information, uncertainty and credit rationing". Quarterly Journal of Economics.

Jaffee, Dwight and Joseph Stiglitz (1990): "Credit rationing" in Handbook of Monetary Economics, Vol. II, B M Friedman and F H Haha (eds.), North Holland.

Kertudo, Jean-Marie (1998): "The BIS consolidated international banking statistics in perspective". International Banking and Financial Market Developments, Bank for International Settlements, August.

Kim, In-June and Yeongseop Rhee (1998): "Currency crises of the Asian countries in a globalised financial market", in The implications of Globalisation of World Financial Markets, The Bank of Korea.

Kletzer, Kenneth M (1984): "Asymmetries of information and LDC borrowing with sovereign risk". The Economic Journal, June.

Krugman, Paul (1991): "International aspects of financial crises", in The Risk of Economic Crisis, Martin Feldstein (ed.), The University of Chicago Press.

Mankiw, N Gregory (1986): "The allocation of credit and financial collapse". The Quarterly Journal of Economics, August.

Masson, Paul (1998): "Contagion: monsoonal effects, spillovers, and jumps between multiple equilibria”. IMF Working Paper No. 98/142, International Monetary Fund, September.

McKinnon, Ronald I and Huw Pill (1998): "International overborrowing: a decomposition of credit and currency risks". World Economy.

Merton, Robert C and Zvi Bodie (1992): "On the management of financial guarantees". Financial Management, Winter.

Milhaupt, Curtis J (1999): “Japan's experience with deposit insurance and failing banks: implications for regulatory design?" Monetary and Economic Studies, August.

Moffett, Michael (1986): “The international interbank market: a behavioural model of credit rationing and bank tiering". Brookings Discussion Papers in International Economics, No. 48, May.

Moshirian, Fariborz and Robert Bishop (1997): "International business: determinants of interbank activities". Journal of International Financial Markets, Institutions and Money.

Ordover, Janusz and Andrew Weiss (1981): "Information and the law: evaluating legal restrictions on competitive contracts". American Economic Review, May. 
Peek, Joe and Eric S Rosengren (1998): "Determinants of the Japan premium: actions speak louder than words". Working Paper No. 98-9, Federal Reserve Bank of Boston, December.

Poulsen, A B (1986): "Japanese bank regulation and the activities of the US offices of Japanese banks". Journal of Money, Credit and Banking.

Rochet, Jean-Charles (1992): "Capital requirements and the behaviour of commercial banks". European Economic Review.

Rochet, Jean-Charles and Jean Tirole (1996): "Inter-bank lending and systemic risk". Journal of Money, Credit and Banking, Part II, November.

Salant, Stephen and Dale Hendersen (1978): "Market anticipations of government gold policies and the price of gold". Journal of Political Economy, August.

Salant, Stephen W (1983): "The vulnerability of price stabilisation schemes to speculative attack". Journal of Political Economy, February.

Saunders, Anthony (1986): "An examination of the contagion effects in the international loan market". Journal of Banking and Finance, Studies in Banking and Finance, Supplement 3.

Saunders, Anthony (1987): "The interbank market, contagion effects and international financial crises". New York University Salomon Brothers Centre Working Paper No. 385, June. Also published in Threats to International Financial Stability, Richard Portes and Alexander K Swoboda, (eds.), Cambridge University Press, 1987.

Stiglitz, Joseph and Andrew Weiss (1981): "Credit rationing in markets with imperfect information". American Economic Review.

Stiglitz, Joseph (1986): "Economics of the public sector". Norton.

Stiglitz, Joseph and Andrew Weiss (1987): "Credit rationing: a reply". The American Economic Review, March.

Stiglitz, Joseph E (1998): "More instruments and broader goals: moving toward the post-Washington consensus". WIDER Annual Lectures No. 2, UNU World Institute for Development Economics Research, The United Nations University.

Stiglitz, Joseph E (1999): "Reforming the global economic architecture: lessons from recent crises". The Journal of Finance.

Terrell Henry S, Robert S Dohner and Barber R Lowry (1989): “The US and UK activities of Japanese banks: 1980-1988". International Finance Discussion Papers No. 361, Board of Governors of the Federal System, Washington, D.C., September.

Van Roij, G (1989): "The international interbank market and the stability of the banking system", in Financing the World Economy in the Nineties, Jacques J Sijben, (ed.), Kluwer Academic Publishers.

World Bank (1999): Global Financial Developments, Washington, D.C.

Zhang, Xiaoming Alan (1999): "Testing for moral hazard in emerging markets lending". IIF Research Papers No. 99-1, Institute of International Finance, Inc., August. 




\section{Recent BIS Working Papers}

No.

70

June 1999

71

June 1999

72

August 1999

73

August 1999

74

August 1999

75

August 1999

76

October 1999

77

October 1999

78

October 1999

79

November 1999

80

November 1999

81

November 1999

82

November 1999

83

January 2000

84

January 2000

85

January 2000
Title

Author

Craig H Furfine

Michael J Fleming and Eli M Remolona

Reserve currency allocation: an alternative methodology

Srichander

Ramaswamy

The Taylor rule and interest rates in the EMU area: a note

Stefan Gerlach and

Gert Schnabel

Gabriele Galati

The dollar-mark axis

A note on the Gordon growth model with nonstationary dividend growth

The price of risk at year-end: evidence from interbank lending

Perceived central bank intervention and market expectations: an empirical study of the yen/dollar exchange rate, 1993-96

Banking and commerce: a liquidity approach

Joseph G Haubrich and João A C Santos

Jonathan McCarthy

Pass-through of exchange rates and import prices to domestic inflation in some industrialised economies

A note on alternative measures of real bond rates

Palle S Andersen

Henri Pagès

Interbank interest rates and the risk premium

Sacrifice ratios and the conduct of monetary policy in conditions of low inflation

Palle S Andersen and William L Wascher

Switching from single to multiple bank lending relationships: determinants and implications

Luísa A Farinha and João A C Santos

What have we learned from recent financial crises and policy responses?

A defence of the expectations theory as a model of US long-term interest rates
William R White

Gregory D Sutton 


ISSN 1020-0959 